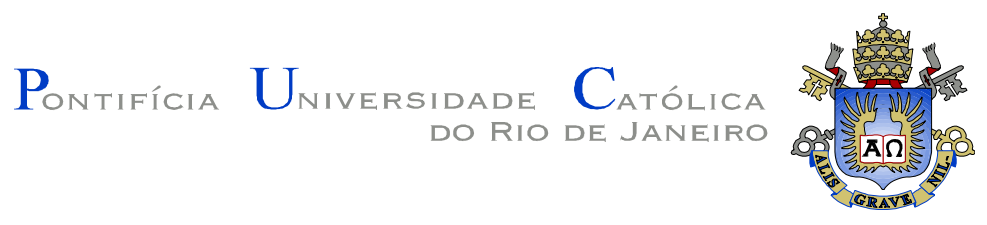

Débora Sol Ferreira Freire

\title{
O Brasil e as transformações no campo da segurança coletiva no pós-Guerra Fria
}

Dissertação apresentada como requisito parcial para a obtenção do grau de Mestre pelo Programa de PósGraduação em Relações Internacionais da PUC-Rio.

Orientador: Prof. Paulo Luiz Moreaux Lavigne Esteves 


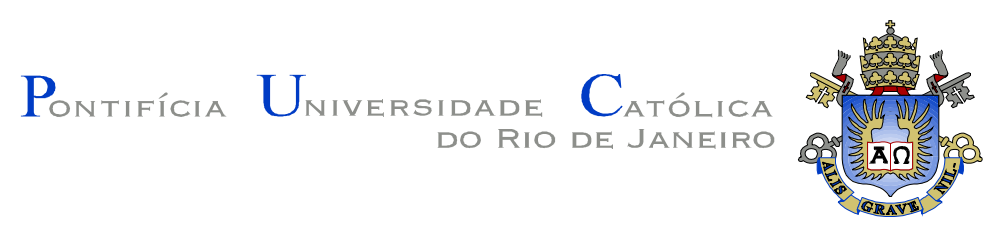

Débora Sol Ferreira Freire

\section{O Brasil e as transformações no campo da segurança coletiva no pós-Guerra Fria}

Dissertação apresentada como requisito parcial para a obtenção do grau de Mestre pelo Programa de PósGraduação em Relações Internacionais do Instituto de Relações Internacionais do Centro de Ciências Sociais da PUC-Rio. Aprovada pela Comissão Examinadora abaixo assinada.

Prof. Paulo Luiz Moreaux Lavigne Esteves Orientador e Presidente Instituto de Relações Internacionais - PUC-Rio

Profa. Mônica Herz Instituto de Relações Internacionais - PUC-Rio

Prof. Carlos Aurélio Pimenta de Faria PUC-Minas

Profa. Mônica Herz Vice-Decana de Pós-Graduação do Centro de Ciências Sociais - PUC-Rio 
Todos os direitos reservados. É proibida a reprodução total ou parcial do trabalho sem a autorização da universidade, da autora e do orientador.

\section{Débora Sol Ferreira Freire}

Graduou-se em Licenciatura e Bacharelado em História na Pontifícia Universidade Católica do Rio de Janeiro, em 2009. Tem interesse na área de Segurança Internacional; Intervenções Humanitárias; Direitos Humanos; Desenvolvimento e Organizações Internacionais.

Ficha Catalográfica

Freire, Débora Sol Ferreira

O Brasil e as transformações no campo da segurança coletiva no pós-Guerra Fria / Débora Sol Ferreira Freire ; orientador: Paulo Esteves. 2012.

142 f. : il. (color.) ; $30 \mathrm{~cm}$

Dissertação (mestrado)-Pontifícia Universidade Católica do Rio de Janeiro, Instituto de Relações Internacionais, 2012.

Inclui bibliografia

1. Relações internacionais - Teses. 2. Nações Unidas. 3. Segurança humana. 4. Intervenção humanitária. 5. Responsabilidade de proteger. 6. Brasil. 7. Não indiferença. 8. MINUSTAH. I. Esteves, Paulo. II. Pontifícia Universidade Católica do Rio de Janeiro. Instituto de Relações Internacionais. III. Título.

CDD: 327 
Dedico esta dissertação à minha mãe, pelo amor e dedicação incondicionais. Obrigada por tudo. 


\section{Agradecimentos}

Agradeço a Deus por sempre iluminar o meu caminho.

Ao CNPq e à PUC-Rio, pelo apoio e financiamento concedidos, essenciais para a realização deste trabalho.

À PUC-Rio, por ter sido mais que uma Universidade durante todo esse tempo e que, sem dúvida, foi o lugar onde passei os melhores anos da minha vida.

Ao meu orientador, Professor Paulo Esteves, que tanto admiro! Obrigada pela confiança, pelos debates qualificados, pela paciência e enorme generosidade.

À minha família, pelo apoio e carinho incondicionais, sem os quais eu não teria chegado até aqui. Em especial, à minha mãe, confidente e colaboradora (muito) ativa dessa dissertação. Ao meu pai, por ser o maior mestre de todos, por sempre estar ao meu lado, me apoiando em todos os projetos da vida e com o mesmo entusiasmo. Aos meus irmãos, pela parceria de toda a vida. Ao meu tio Victor, por sempre admirar e se interessar por tudo que faço. Ao meu vô Jorge, à minha bisa Ernestina e minha avó Therezinha, pelo amor que me dedicaram.

À Banca Examinadora, Professor Carlos Aurélio Pimenta de Faria e Professora Mônica Herz, por seu tempo dispensado, pelos preciosos comentários, pela compreensão e gentileza em todos os momentos.

Aos meus queridos professores do Instituto de Relações Internacionais (IRI), em especial àqueles que foram fundamentais para a realização deste trabalho: Professora Mônica Herz, pelo incentivo desde o início do Mestrado e pelos debates sobre Segurança; Professora Letícia Pinheiro, por me introduzir ao gigante universo da Política Externa Brasileira; Professor Kai Kenkel, pelas observações valiosas e construtivas e Professora Carolina Moulin, pela importante formação teórica.

Aos funcionários do IRI, especialmente, Lia Gonzalez, Vera Lira e Cláudia Darze, pela assistência durante todo o curso.

Ao Mauro, pelo amor, por me fazer rir nos momentos difíceis, pelos livros (fundamentais) recebidos de presente e por ter sido um leitor crítico essencial do trabalho.

Aos meus queridos amigos, pela torcida, pelo carinho e pela compreensão por todos os encontros perdidos! Em particular, à Daniela Yunes, por ter sido uma ouvinte paciente de todos os dilemas e colaboradora deste trabalho e à Aline Passeri, pela cumplicidade de sempre e apoio fundamental durante esse período.

Aos meus colegas do Mestrado, que tornaram essa jornada muito mais alegre e divertida. Em particular, agradeço ao Paulo Chamon, pela parceria, pelos incentivos nos momentos de desespero e pelas discussões teóricas intermináveis, principalmente através dos e-mails gigantes trocados ao longo do curso. 


\section{Resumo}

Freire, Débora Sol Ferreira; Esteves, Paulo Luiz Moreaux Lavigne. O Brasil e as transformações no campo da segurança coletiva no pósGuerra Fria. Rio de Janeiro, 2012. 142p. Dissertação de Mestrado Instituto de Relações Internacionais, Pontifícia Universidade Católica do Rio de Janeiro.

A dissertação pretende discutir o posicionamento do Brasil em face das transformações da agenda de segurança internacional no pós- Guerra Fria. Para tanto, serão realizados três movimentos. O primeiro movimento se refere à análise do desenvolvimento das normas de segurança coletiva desde a Guerra Fria até a emergência do conceito de Responsabilidade de Proteger (R2P), com especial ênfase na década de noventa e nas transformações normativas que autorizaram as práticas de intervenção humanitária. O segundo movimento tem por objetivo discutir, através do discurso da diplomacia brasileira, o posicionamento do Brasil com relação ao tema da intervenção e de peacebuilding, principalmente no governo do presidente Fernando Henrique Cardoso (19952002). O terceiro movimento busca salientar, a partir dos discursos da diplomacia brasileira, as estratégias do governo Luiz Inácio Lula da Silva (20032010) que permitiram a participação brasileira no comando da Missão de Estabilização das Nações Unidas para o Haiti (MINUSTAH), em 2004, e um maior engajamento com a $\mathrm{R} 2 \mathrm{P}$, inclusive com a proposta de responsabilidade ao proteger (RWP).

\section{Palavras-chave}

Nações Unidas; segurança humana; intervenção humanitária; responsabilidade de proteger; Brasil; não indiferença; MINUSTAH. 


\section{Abstract}

Freire, Débora Sol Ferreira; Esteves, Paulo Luiz Moreaux Lavigne (Advisor). Brazil and the transformations in international security agenda in the post-Cold War era. Rio de Janeiro, 2012. 142p. MSc. Dissertation - Instituto de Relações Internacionais, Pontifícia Universidade Católica do Rio de Janeiro.

This dissertation explores the position of Brazil in view of the major transformations in international security agenda in the post-Cold War era. For this, three movements take place. The first movement is related to the analysis of the development of norms of collective security since the Cold War until the emergence of the concept of Responsibility to Protect (R2P), with special emphasis in the nineties and changes in norms that allowed the practice of humanitarian intervention. The second movement aims to discuss, through the discourse of Brazilian diplomacy, the position of Brazil on the issue of intervention and peacebuilding, especially under President Fernando Henrique Cardoso (1995-2002). The third movement aims to stress, from the speeches of Brazilian diplomacy, the government strategies of Luiz Inácio Lula da Silva (2003-2010) that allowed the participation of Brazil in charge of the Mission of the United Nations Stabilization for Haiti (MINUSTAH), in 2004, and a greater engagement with $\mathrm{R} 2 \mathrm{P}$, including the proposal of responsibility while protecting (RWP).

\section{Keywords}

United Nations; human security; humanitarian intervention; responsibility to protect; Brazil; non-indifference; MINUSTAH. 


\section{Sumário}

Introdução

Capítulo 1 - As transformações no campo da segurança coletiva 14

Definindo "Intervenção Humanitária"

Intervenção Humanitária e Direitos Humanos na ONU

durante a Guerra Fria

Intervenções durante a Guerra Fria

Os anos 90 e a nova agenda de segurança da ONU 26

O conceito de Segurança Humana 34

Subdesenvolvimento como um problema de segurança 37

A Intervenção Humanitária nos anos $90 \quad 38$

$\begin{array}{ll}\text { A Responsabilidade de Proteger (R2P) } & 47\end{array}$

Capítulo 2 - O Brasil e a nova agenda de segurança da ONU 56

O Brasil e as Operações de Paz 67

O Brasil e a agenda de segurança da ONU nos anos $90 \quad 68$

A perspectiva brasileira na primeira intervenção no Haiti (1994) 73

Capítulo 3 - O Brasil e o campo da segurança: uma nova proposta 78 O Brasil e a MINUSTAH (2004) 82

A MINUSTAH $\quad 83$

O Brasil e a Responsabilidade de Proteger (R2P) 100

A proposta brasileira: Responsabilidade ao Proteger (RWP) 104

O Brasil e a Comissão para Consolidação da Paz

(Peacebuilding Commission)

$\begin{array}{ll}\text { Conclusão } & 121\end{array}$

Bibliografia 124 


\section{Lista de siglas}

AGNU - Assembleia Geral das Nações Unidas

ASEAN - Association of Southeast Asian Nations

CARE - Cooperative for American Relief Everywhere

CICV - Comitê Internacional da Cruz Vermelha

CSNU - Conselho de Segurança das Nações Unidas

DIH - Direito Internacional Humanitário

ECOMOG - Economic Community of West African States Monitoring Group

ECOSOC - Economic and Social Council

ECOWAS - Economic Community of West African States

EUA - Estados Unidos da América

GNP - Gross National Product

ICISS - International Commission on Intervention and State Sovereignty

IDH - Índice de Desenvolvimento Humano

INTERFET - Força Internacional para o Timor-leste

MINUSTAH - Missão das Nações Unidas para a Estabilização no Haiti

MSF - Médicos Sem Fronteiras

MTCR - Regime de Controle de Tecnologia de Mísseis

NATO - North Atlantic Treaty Organization

OAS - Organization of American States

OEA - Organização dos Estados Americanos

OIC - Organização Internacional do Comércio

OMP - Operações de Manutenção da Paz

ONG - Organização Não Governamental

ONU - Organização das Nações Unidas

OTAN - Organização do Tratado do Atlântico Norte

OUA - Organização da Unidade Africana

OXFAM - Oxford Committee for Famine Relief

PBC - Peacebuilding Commission

PDN - Política de Defesa Nacional

PIB - Produto Interno Bruto 
PNUD - Programa das Nações Unidas para o Desenvolvimento

R2P - Responsibility to Protect

RWP - Responsibility while protecting

$\mathrm{RDH}$ - Relatório de Desenvolvimento Humano

SGP - Sistema Geral de Preferências

TNP - Tratado de Não Proliferação Nuclear

UA - União Africana

UNAMIR - United Nations Assistance Mission in Rwanda

UNAMSIL - United Nations Mission in Sierra Leone

UNAVEM - United Nations Angola Varification Mission

UNEF - United Nations Emergency Force

UNITAF - Unified Task Force

UNOGBIS - United Nations Peacebuilding Support Office in Guinea-

Bissau

UNOMOZ - United Nations Operation in Mozambique

UNOSOM - United Nations Operation in Somalia

UNPROFOR - United Nations Protection Force

UNTAET - United Nations Transitional Administration in East Timor

WEOG - Western European and Others Group 


\section{Introdução}

O trabalho pretende discutir o posicionamento do Brasil em face das transformações da agenda de segurança internacional no pós-Guerra Fria. Para tanto, serão realizados três movimentos. O primeiro movimento se refere à análise do desenvolvimento das normas de segurança coletiva desde a Guerra Fria até a emergência do conceito de Responsabilidade de Proteger (R2P), com especial ênfase na década de noventa e nas transformações normativas que autorizaram as práticas de intervenção humanitária. O objetivo neste capítulo é compreender dois principais pontos: como o desenvolvimento passa a ser um elemento essencial para a prevenção de conflitos e para o alcance da paz durável; e como as práticas de intervenção se articulam com a noção de emergência humanitária. Com esta finalidade, serão analisados os documentos produzidos no âmbito do Secretariado Geral das Nações Unidas, do Programa das Nações Unidas para o Desenvolvimento e do Conselho de Segurança.

O segundo movimento tem por objetivo discutir, através do discurso da diplomacia brasileira, o posicionamento do Brasil com relação ao tema da intervenção e de peacebuilding, ${ }^{1}$ principalmente no governo do presidente Fernando Henrique Cardoso (1995-2002). A análise será conduzida a partir de alguns eixos de estruturação da política externa brasileira (PINHEIRO, 2000), segundo a perspectiva de analistas e diplomatas: a busca de autonomia, a primazia do desenvolvimento e o compromisso do país com o multilateralismo.

O terceiro movimento busca salientar, a partir dos discursos da diplomacia brasileira, as estratégias que permitiram uma mudança de postura da política externa no governo do presidente Luiz Inácio Lula da Silva (2003-2010), de forma que o Brasil aceitasse participar do comando da Missão de Estabilização das Nações Unidas para o Haiti (MINUSTAH) e tivesse um maior engajamento com a R2P, propondo até uma nova ideia: a responsabilidade ao proteger. Ademais, será analisada a participação brasileira na criação da Comissão de Consolidação da Paz (Peacebuilding Commission) como parte do plano brasileiro de exercer liderança no campo do desenvolvimento.

\footnotetext{
${ }^{1}$ As definições de peacebuilding são fluidas, mas o termo costuma ser empregado para definir o envolvimento das forças internacionais na reconstrução dos países em situação de pósconflito, embora seja possível que tais atividades ocorram ao longo, ou até mesmo, antes da eclosão do conflito.
} 
A pesquisa orientou-se por duas hipóteses de trabalho: (i) a adoção do conceito de "não indiferença" como um complemento ao princípio da "não intervenção" parece alinhar o país aos preceitos liberais da governança internacional no que concerne às práticas de peacebuilding e permite ao Brasil resistir aos avanços desses preceitos no que diz respeito ao problema da intervenção; (ii) a apropriação da noção de "não indiferença", contudo, cria a possibilidade de o país diferenciar-se com relação aos países do Norte ao enfatizar sua experiência em lidar com os problemas de combate à fome e à pobreza.

Para realizar os três movimentos e investigar as hipóteses propostas, utilizou-se o método da análise de discurso, tal como proposto por Lene Hansen (2006), no qual as práticas textuais são orientadas pela interação com outros textos, ou a partir do que ela denomina intertextualidade, e não por um contexto social imediato. A intertextualidade constrói uma rede que permite a articulação entre os textos, possibilitando identificar a associação de diferentes modos de autoridade, construção, interligação e mobilização de discursos que viabilizam o exercício do poder (HANSEN, 2006). Der Derian também destaca que as relações internacionais devem ser entendidas através de uma abordagem intertextual, "no sentido de uma investigação crítica dentro da área de pensamento onde não há um árbitro final da verdade, onde o significado é derivado de inter-relações de textos, e o poder está envolvido pelo problema da linguagem e outras práticas de significado" (DER DERIAN; SHAPIRO, 1989, p.6, tradução nossa).

Para Shapiro, a linguagem é entendida como um conjunto de ativos discursivos que constituem identidades, dispõem espaços sociais, e agenciam práticas políticas (SHAPIRO, 1992). Segundo o autor, “[...] nosso entendimento sobre conflito, guerra ou, mais geral, do próprio espaço da política internacional, é sempre mediado por meios de representação, e, portanto, por todos os mecanismos envolvidos na construção do texto - gramática, retórica e narrativa [...]” (DER DERIAN; SHAPIRO, 1989, p.12, tradução nossa).

Der Derian ressalta a importância do discurso na construção da realidade, pretendendo revelar que as práticas textuais dominantes são responsáveis pela produção dos sistemas de significado e valor, que, por sua vez, orientam e legitimam certas ações e políticas em detrimento de outras, que são excluídas e marginalizadas. Nesse sentido, o autor salienta que é fundamental questionar essas formas privilegiadas de representação "cuja dominância levou à aceitação de 
sujeitos, objetos, atos, e temas através dos quais a política mundial é construída" (DER DERIAN; SHAPIRO, 1989, p.12, tradução nossa). Nessa linha, o discurso vigente da teoria das relações internacionais deve ser visto tanto como fruto de um processo dinâmico de intertextualidades como consequência da contingência histórica, do acaso. De forma resumida, esta abordagem tem como objetivo principal desnaturalizar as formas habituais de teorizar e de agir nas relações internacionais a partir da adoção de uma estratégia intertextual.

Através da análise de discurso, o trabalho buscou construir uma rede que permitisse compreender como os textos se articulam e constroem certa autoridade, em assunto determinado. No primeiro capítulo, a análise de discurso viabilizou a construção de uma rede intertextual que permitiu perceber o desenvolvimento de um nexo discursivo entre segurança e desenvolvimento, e segurança e humanitarismo, através do conceito de segurança humana. A articulação entre esses elementos possibilitou duas ações essenciais: interpretar as situações de crise humanitária como um problema de segurança internacional e conceber o desenvolvimento como o principal instrumento de prevenção de conflitos e de consolidação de uma paz durável. Esse novo léxico não apenas indica uma mudança na agenda de segurança da ONU, mas também constrói essa nova realidade. Dessa forma, o conceito de segurança humana passa a legitimar e orientar a prática das operações de paz como um todo a partir dos anos noventa. Pode-se dizer, portanto, que é a partir desse conceito que se desdobram duas práticas transversais: intervenção humanitária e peacebuilding.

Além disso, o trabalho pautou-se pela analítica interpretativa e pela genealogia foucaultianas, percebendo que interpretar não é buscar uma verdade, mas entender os embates da história, as emergências, concebidas não como figuras sucessivas de uma mesma significação, mas como "efeitos de substituições, reposições e deslocamentos, de conquistas disfarçadas, de inversões sistemáticas" (FOUCAULT, 2005, p.271). No capítulo três, a participação do Brasil no comando da MINUSTAH e o maior engajamento do país com a R2P nos últimos anos podem ser compreendidos muito mais pelo descontínuo da história da política externa do que pela permanência de tradições. Nesse contexto, buscouse analisar a postura brasileira no campo da segurança, a partir do governo Lula, no que ela pode ter de singular e aguda (FOUCAULT, 2005, p.272), ainda que haja um esforço de analistas e diplomatas por sublinhar as continuidades. 


\section{Capítulo 1 - As transformações no campo da segurança coletiva}

Este capítulo pretende analisar o desenvolvimento das normas de segurança coletiva desde a Guerra Fria até a emergência do conceito de Responsabilidade de Proteger, com especial ênfase à década de noventa e às transformações normativas que autorizaram as práticas de intervenção humanitária. Tal análise nos permitirá compreender como as noções de emergência e prevenção articulam as práticas de intervenção e desenvolvimento, no âmbito das Operações de Manutenção da Paz. Para tanto, iremos proceder à análise documental dos principais documentos produzidos no âmbito do Secretariado Geral das Nações Unidas, do Programa das Nações Unidas para o Desenvolvimento e, finalmente, do Conselho de Segurança, buscando identificar: (i) como segurança coletiva é definida; (ii) quais são as ameaças à segurança coletiva; e, (iii) como tais ameaças devem ser combatidas. Tal análise permitirá desenhar o ambiente de transformação institucional no qual o Brasil está inserido. Entretanto, é importante destacar que a intenção não é abordar todas as questões e eventos desse período histórico - o que seria uma tarefa interminável - mas apenas apresentar e discutir os aspectos centrais do processo de transformação institucional do regime de Segurança Coletiva, em curso após a Guerra Fria. Entre esses aspectos, o problema da intervenção humanitária ganha destacada relevância, particularmente quando se tem em conta o objetivo final desse trabalho de discutir a posição brasileira no campo da segurança internacional. Nesse sentido, ainda que de forma não cronológica, o capítulo se estrutura, primeiramente, a partir da indagação acerca do conceito de "Intervenção Humanitária" para, em seguida, buscar compreender como foi tratado nos contextos da Guerra Fria e do período que lhe é imediatamente posterior.

\section{Definindo "Intervenção Humanitária"}

A discussão das intervenções para fins humanitários tem origem nas teorias da Guerra Justa. E um dos primeiros usos do conceito está na obra International Law (1880), de William Edward Hall. Desde então, o conceito de 
intervenção humanitária vem sofrendo transformações em seu conteúdo e na forma como é apropriado para fins políticos. Atualmente, a definição mais corrente do conceito, apesar de não ser absoluta, é bastante indicativa das mudanças normativas no campo da segurança coletiva no pós- Guerra Fria. Mais que isso, ela é, em si, um fator dessas mudanças. Segundo Gareth Evans e Mohamed Sahnoun (2002, p.99), intervenção humanitária corresponde a uma "coercive action against a state to protect people within its borders from suffering grave harm".

As ações de intervenção humanitária costumam ser confundidas com aquelas normalmente denominadas de "assistência humanitária" ou "auxílio humanitário". O humanitarismo envolve assistência não militar por organizações humanitárias $^{2}$ e visa salvar vidas e fornecer alívio ao sofrimento humano em situações de ameaças causadas tanto por eventos naturais (terremotos, furacões, tsunamis) como por seres humanos (guerra, genocídio, conflito étnico e outras formas de violência organizada) (BARNETT; WEISS, 2008). Michael Barnett e Thomas G. Weiss (2008, p.10) ainda destacam que muitos dentro do setor humanitário tendem a conceber o ato humanitário ideal como aquele que visa honrar os princípios de humanidade, neutralidade, imparcialidade, e independência - apesar de os autores ressaltarem as dificuldades na aplicação de tais ideais.

Já o conceito de intervenção humanitária pode ser entendido, segundo Howard Adelman, como o "uso da força física dentro do território soberano de outro Estado por Estados ou pelas Nações Unidas com a finalidade de proteger ou prover ajuda emergencial à população deste território" (BOYLE, 2006, pp. 32, 54 apud KENKEL, 2012, p.4, tradução do autor).

Holzgrefe oferece outra interessante definição, explicitando os elementos centrais do conceito:

the threat or the use of force across state borders by a state (or a group of states) aimed at preventing or ending widespread and grave violations of the fundamental human rights of individuals other than its own citizens, without the

\footnotetext{
${ }^{2}$ Segundo Barnett e Weiss (2008), dentro da categoria de organizações humanitárias podemos incluir tanto organizações não governamentais (ONGs), como organizações intergovernamentais, ou ainda fundações filantrópicas. O critério é que o único objetivo da organização seja salvar vidas humanas e aliviar o sofrimento humano.
} 
permission of the state within whose territory force is applied (HOLZGREFE, 2003, p.18).

A definição que o autor apresenta estabelece quatro critérios essenciais para que uma ação seja percebida como uma intervenção humanitária. O primeiro é que a ameaça ou uso da força tem que estar obrigatoriamente contidos na ação o que, neste caso, se restringe à força militar, não incluindo, portanto, a intervenção por outros meios, como diplomáticos ou econômicos; o segundo é que a intervenção militar tem que acontecer por um Estado, ou um grupo de Estados, em outro Estado soberano; o terceiro é que o propósito da intervenção tem que ser humanitário, com o objetivo de proteger e defender os direitos humanos de outros indivíduos que não os cidadãos dos Estados interventores, ${ }^{3}$ e o quarto e último indica que a intervenção não pode ter a permissão ou convite do Estado receptor, pois caso haja a permissão, a ação militar deixa de ser considerada uma intervenção e passa a ser uma ajuda internacional.

Cabe notar que o pressuposto de consentimento das partes beligerantes foi pensado, à época da elaboração da Carta das Nações Unidas, em um contexto em que a guerra entre Estados era o principal foco de preocupação da segurança coletiva. O horror da Segunda Guerra era uma realidade recente. Por isso, a Carta descreve exclusivamente os Estados como partes beligerantes. Com o fim da Guerra Fria e a mudança de foco para as guerras intraestatais, os estudiosos deste tema costumam entender que há uma ampliação de atores envolvidos no conflito, com uma combinação de agentes públicos e privados e de esferas estatais e não estatais. As partes beligerantes passam a corresponder aos grupos políticos dentro do Estado - étnicos, culturais ou ligados por outro laço de identidade (KALDOR, 2001). Isso pode criar dúvidas sobre a definição de intervenção. Afinal, quem possui o direito de consentir? O Direito Internacional Público atualmente estabelece que "o ato de consentir [...] revela a autonomia do Estado de aderir ou não a direitos e deveres no plano internacional [...]" (MAZZUOLI, 2008). Desse modo, o ato de consentir ainda cabe ao Estado. Nesse sentido, à luz da emergência da norma de responsabilidade de proteger, podemos entender que houve uma intervenção quando não há o consentimento do Estado - ou por incapacidade

\footnotetext{
${ }^{3} \mathrm{O}$ resgate ou proteção de cidadãos em terras estrangeiras se aproxima do conceito de legítima defesa, mas no passado este tipo de ação já foi considerado uma intervenção humanitária (FINNEMORE, 2003).
} 
(como no caso de Estados falidos) ou falta de vontade deste exercer sua responsabilidade de garantir proteção e bem-estar aos cidadãos, como foi apresentado no Relatório da ICISS (International Commission on Intervention and State Sovereignty) ${ }^{4}$ :

Where a population is suffering serious harm, as a result of internal war, insurgency, repression or state failure, and the state in question is unwilling or unable to halt or avert it, the principle of non-intervention yields to the international responsibility to protect (ICISS, 2001, grifo nosso).

Isso implica novo entendimento do princípio da soberania: de um direito absoluto para soberania como responsabilidade. Tal transformação será tratada ainda nesse capítulo. Antes disso, contudo, cabe ressaltar que a discussão sobre quem tem o direito de consentir não está fechada e, em algumas definições, isso aparece de forma confusa, como encontrado em uma explicação sobre as ações de imposição da paz (ou peace-enforcement).

Peace-enforcement ou imposição da paz define hoje a intervenção de um país ou coalizão de países, diretamente entre as partes em conflito - sem sua autorização ou do país em que ocorre o conflito e, algumas vezes, sem autorização do Conselho de Segurança (NEVES, 2009, p.16, grifo nosso).

\section{Intervenção humanitária e Direitos Humanos na ONU durante a Guerra Fria}

Martha Finnemore (2003) lembra que as intervenções de caráter humanitário não são uma prática recente da política internacional, sendo muito comum no século XIX para a proteção de minorias religiosas, como foi o caso da incursão da França na Síria, em 1860, para deter os ataques contra os cristãos maronitas e as várias ações militares das potências europeias em defesa das minorias cristãs no Império Otomano, também no mesmo período (EVANS, 2008, p.19). Nesse contexto, a autora ressalta que as antigas práticas intervencionistas tinham o intuito de promover a proteção de conacionais, ou pessoas da mesma identidade étnica e religiosa, enquanto as intervenções no pós-Segunda Guerra

\footnotetext{
${ }^{4}$ Comissão Internacional sobre Intervenção e Soberania Estatal, em português.
} 
passam a ter a finalidade de proteger indivíduos das mais diferentes identidades e que não possuem necessariamente relação com os Estados interventores (FINNEMORE, 2003; KENKEL, 2012). Essa mudança se traduz em uma ampliação no número de populações vistas como dignas de proteção (KENKEL, 2012, p.2).

Durante a Guerra Fria, muitos avanços foram feitos no sentido de codificar o conceito de direitos humanos em um regime jurídico internacional - tanto para situações de guerra quanto para tempos de paz (KENKEL, 2012, p.5). Isso se deveu muito aos impactos da Segunda Guerra Mundial e do Holocausto. Apesar da tentativa, sob o Pacto da Liga das Nações, da institucionalização das normas para intervenção com o estabelecimento de proteção às minorias nacionais, o regime falhou na contenção da barbárie do Shoah (KENKEL, 2012, p.3).

De acordo com uma reflexão de Hannah Arendt, descrita por Celso Lafer, "na inexistência de uma tutela jurídica organizada, são os acidentes da simpatia, a força da amizade ou a graça do amor os únicos elementos que oferecem a um refugiado a base precária que confirma a sua dignidade humana" (ARENDT, 2008, p.306). Refugiado, neste caso, pode ser substituído por diversas outras condições humanas: vítimas de guerras civis, de regimes totalitários e de todo tipo de violência. Há, neste momento, como destaca Finnemore, um alargamento da definição de "humanidade" aos olhos do Ocidente (FINNEMORE, 2003, p.54). A vontade de que nunca mais aqueles terríveis eventos se repetissem deram ímpeto à luta pelos Direitos Humanos (ABIEW, 1999, p.75 apud KENKEL, 2012, p. 8).

As Convenções de Genebra de 1949 e seus Protocolos Adicionais exerceram um papel crucial na consolidação do Direito Internacional Humanitário $(\mathrm{DIH})^{\mathbf{5}}$ - ampliando o direito anterior de Genebra e Haia - porque foram responsáveis por sistematizar as regras de conduta dos conflitos armados (jus in bello), ${ }^{6}$ visando limitar os seus terríveis efeitos. Um dos principais avanços é o estabelecimento da distinção entre combatentes e não combatentes (que seriam civis, profissionais de saúde e de socorro e os que não mais participam das

\footnotetext{
${ }^{5}$ DIH é um ramo do direito aplicável somente em situações de conflito. O Direito Internacional, de forma ampla, pode ser entendido como um "conjunto de normas e princípios encontrados nos tratados e convenções internacionais e oriundos do costume" (HERZ; HOFFMANN, 2004. p. 22).

${ }^{6}$ Tradicionalmente, distingue-se o jus ad bellum do jus in bello. Este último é a regulamentação da guerra: as normas aplicáveis aos beligerantes e aquelas obrigações decorrentes do estado de guerra. Aqui, insere-se o Direito Humanitário. O primeiro refere-se ao direito à guerra (BYERS, 2007).
} 
hostilidades - soldados feridos, doentes, náufragos e prisioneiros de guerra). Os dois protocolos adicionais de $1977^{7}$ codificaram, respectivamente, a situação das vítimas de guerras internacionais e de guerras civis (KENKEL, p.6).

Em 1948, foi publicada a Declaração Universal de Direitos Humanos (de caráter recomendatório) e a Convenção para a Prevenção e a Repressão do Crime de Genocídio (de caráter obrigatório). Em 1966, outros três tratados internacionais contribuiriam para a expansão do corpo do direito internacional dos direitos humanos: a Convenção Sobre a Eliminação de Todas as Formas de Discriminação; a Declaração sobre os Direitos Civis e Políticos; e a Declaração sobre os Direitos Econômicos, Sociais e Culturais. Foram adotados ainda os documentos contra a violação dos direitos da mulher (1979), contra a tortura (1984), e sobre os direitos da criança (1989). ${ }^{\mathbf{8}}$ Cabe lembrar outro passo importante no âmbito do Direito Internacional, já na década de noventa, com a aprovação do Estatuto de Roma, em 1998, que prevê a criação do Tribunal Penal Internacional vinculado à ONU. Este é um passo significativo em direção a um novo entendimento sobre soberania, uma vez que punir os autores de crimes contra a humanidade, de crimes de guerra, de genocídio e de agressão passa a ser mais fundamental do que as garantias legais concedidas sob o princípio da soberania tradicional.

A criação do Comitê Internacional da Cruz Vermelha (CICV), em 1863, em Genebra, foi outro importante marco no campo do Direito Internacional Humanitário. Durante a Batalha de Solférino, ${ }^{9}$ Henry Dunant é testemunha da falta de tratamento dado às pessoas feridas no campo de batalha $\mathrm{e}$ as consequências nefastas disso - seis mil combatentes morreram em um só dia. Essa experiência o impulsionou a convocar uma Conferência Internacional em Genebra para fundar uma organização com o objetivo de proteger os direitos dos feridos durante a guerra. A primeira Convenção do então recente Movimento da Cruz Vermelha foi realizada em 1867 e os Estatutos foram enunciados em 1928.

O trabalho do CICV de assegurar a proteção e a assistência humanitária às vítimas de lutas e conflitos armados, contribuindo na promoção das leis que

\footnotetext{
${ }^{7}$ Disponível em: $\quad<$ http://www.icrc.org/por/war-and-law/treaties-customary-law/genevaconventions/index.jsp $>$. Acesso em: 2 de março de 2012.

${ }^{8}$ Disponível em: <http://www.onu.org.br/a-onu-em-acao/a-onu-e-os-direitos-humanos/> Acesso em: 2 de março de 2012.

${ }^{9}$ Confronto entre os austríacos, que marcharam sobre o Norte da Península Itálica, e as forças franco-piemontesas, que se opuseram ao avanço austríaco.
} 
protegem as vítimas da guerra, tem como base as Convenções de Genebra de 1949, seus Protocolos Adicionais, seus Estatutos - assim como os do Movimento Internacional da Cruz Vermelha e do Crescente Vermelho - e as resoluções das Conferências Internacionais da Cruz Vermelha e do Crescente Vermelho. O CICV é encarregado de monitorar a aplicação do Direito Internacional Humanitário. Jean Pictet, no livro The Fundamental Principles of the Red Cross, identifica os sete princípios fundamentais que definem o humanitarismo e orientam as atividades da organização no mundo: 1 - Humanidade; 2 - Imparcialidade; 3 Neutralidade; 4 - Independência; 5 - Voluntariado; 6 - Unidade; 7 Universalidade (PICTET, 1979 apud BARNETT; WEISS, 2008, p.10).

Os avanços na regulamentação internacional de direitos humanos também incluem a adoção da Carta das Nações Unidas, em 1945. Nela, está reafirmada "[...] a fé nos direitos fundamentais do homem, na dignidade e no valor do ser humano, na igualdade de direito dos homens e das mulheres, assim como das nações grandes e pequenas [...]" (ONU, 1945, p.3). Além de estabelecer no artigo $1^{\mathrm{o}}, \S 3^{\mathrm{o}}$ o compromisso dos Estados-membros de "promover e estimular o respeito aos direitos humanos e às liberdades fundamentais para todos, sem distinção de raça, sexo, língua ou religião" (ONU, 1945, p.5), o que inclui a busca pela “cooperação internacional para resolver os problemas internacionais de caráter econômico, social, cultural ou humanitário" (ONU, 1945, p.5). No Capítulo IX, artigos 55 e 56, o texto explicita a associação entre a paz e o respeito universal e efetivo dos direitos humanos.

\footnotetext{
Artigo 55

Com o fim de criar condições de estabilidade e bem-estar, necessárias às relações pacíficas e amistosas entre as Nações, baseadas no respeito ao princípio da igualdade de direitos e da autodeterminação dos povos, as Nações Unidas favorecerão:

c) o respeito universal e efetivo dos direitos humanos e das liberdades fundamentais para todos, sem distinção de raça, sexo, língua ou religião (ONU, 1945, pp.33-34, grifo nosso).

Artigo 56

Para a realização dos propósitos enumerados no artigo 55, todos os Membros da Organização se comprometem a agir em cooperação com esta, em conjunto ou separadamente (ONU, 1945, p.34, grifo nosso).
}

Ao mesmo tempo, o $\S 4^{\circ}$, do artigo $2^{\circ}$ estabelece que a ameaça ou o uso da força devem ser evitados porque são ações incompatíveis com os propósitos da 
ONU: "Todos os Membros deverão evitar em suas relações internacionais a ameaça ou o uso da força contra a integridade territorial ou a dependência política de qualquer Estado, ou qualquer outra ação incompatível com os Propósitos das Nações Unidas" (ONU, 1945, p.6, grifo nosso).

$\mathrm{O} \S 7^{\circ}$, do artigo $2^{\circ}$, ainda amplia a proibição de intervenções àquelas que não envolvem o uso da força. Contudo, também consagra uma das exceções fundamentais ao princípio da não intervenção, que está descrita no Capítulo VII da Carta:

Nenhum dispositivo da presente Carta autorizará as Nações Unidas a intervirem em assuntos que dependam essencialmente da jurisdição de qualquer Estado ou obrigará os Membros a submeterem tais assuntos a uma solução, nos termos da presente Carta; este princípio, porém, não prejudicará a aplicação das medidas coercitivas constantes do Capitulo VII (ONU, 1945, p.7, grifo nosso).

O Capítulo VII - sobre ação relativa a ameaça à paz, ruptura da paz e atos de agressão - constitui, portanto, uma exceção prevista ao princípio de não intervenção, conforme preconiza o artigo 42:

No caso de o Conselho de Segurança considerar que as medidas previstas no Artigo 41 seriam ou demonstraram que são inadequadas, poderá levar a efeito, por meio de forças aéreas, navais ou terrestres, a ação que julgar necessária para manter ou restabelecer a paz e a segurança internacionais. Tal ação poderá compreender demonstrações, bloqueios e outras operações, por parte das forças aéreas, navais ou terrestres dos Membros das Nações Unidas (ONU, 1945, p.26, grifo nosso).

Aqui fica claro que uma ação coercitiva constitui uma ação com utilização de força militar, excluindo assim, a intervenção por outros meios, como diplomáticos ou econômicos. Além disso, em última instância, a competência para decidir sobre a necessidade de uma ação coercitiva ou não, é do Conselho de Segurança. Note-se, no entanto, que a resolução 377, de 1950 (ONU, 1950), intitulada de Uniting for Peace, estabelece que em casos de falta de unanimidade dos membros permanentes, a responsabilidade das decisões para manter e restaurar a segurança e paz internacional passa para a Assembleia Geral: 
Resolves that if the Security Council, because of lack of unanimity of the permanent members, fails to exercise its primary responsibility for the maintenance of international peace and security in any case where there appears to be a threat to the peace, breach of the peace, or act of aggression, the General Assembly shall consider the matter immediately with a view to making appropriate recommendations to Members for collective measures, including in the case of a breach of the peace or act of aggression the use of armed force when necessary, to maintain or restore international peace and security. If not in session at the time, the General Assembly may meet in emergency special session within twenty-four hours of the request therefor. Such emergency special session shall be called if requested by the Security Council on the vote of any seven members, or by a majority of the Members of the United Nations (ONU, 1950, grifos nossos).

Além disso, no artigo 51, é estabelecido o direito do uso da força em casos de legítima defesa individual ou coletiva:

\begin{abstract}
Nada na presente Carta prejudicará o direito inerente de legítima defesa individual ou coletiva no caso de ocorrer um ataque armado contra um Membro das Nações Unidas, até que o Conselho de Segurança tenha tomado as medidas necessárias para a manutenção da paz e da segurança internacionais. As medidas tomadas pelos Membros no exercício desse direito de legítima defesa serão comunicadas imediatamente ao Conselho de Segurança e não deverão, de modo algum, atingir a autoridade e a responsabilidade que a presente Carta atribui ao Conselho para levar a efeito, em qualquer tempo, a ação que julgar necessária à manutenção ou ao restabelecimento da paz e da segurança internacionais. (ONU, 1945, pp.30-31, grifos nossos).
\end{abstract}

A Carta das Nações Unidas reflete um dos principais propósitos da organização: realizar o sistema de segurança coletivo. Nesse sentido, além do direito permitido de autodefesa, todas as "demais decisões sobre o uso da força passam a ser subordinadas ao compromisso internacional. Garantir a ordem internacional seria então o motivo legítimo por excelência para ir à guerra" (HERZ; HOFFMANN, 2004, p. 84). A posterior elaboração do conceito de segurança humana ampliará os critérios que definem se um evento é ou não uma ameaça à paz e à segurança internacionais. Concomitantemente, o conceito permitirá que se estendam as possibilidades do uso da força, como no caso das intervenções humanitárias.

Segundo Kai Kenkel, três fenômenos demonstraram o desenvolvimento da norma de intervenção humanitária nas Nações Unidas durante a Guerra Fria: os esforços em lidar com os regimes de apartheid, a onda de descolonizações, e a 
emergência de organizações não governamentais humanitárias (KENKEL, 2012, p.9). Segundo o autor, isso demonstrava, já na década de 50 e 60, uma preocupação com a segurança interna dos Estados e as formas de governos como potenciais ameaças à paz internacional e à segurança (KENKEL, 2012, p.9). Kai Kenkel ressalta, por exemplo, os instrumentos usados para condenar e combater o regime da África do Sul, como a aprovação da resolução 1761 (ONU, 1962) pela Assembleia Geral, de 6 de novembro de 1962, que estabelecia a Comissão Especial das Nações Unidas contra o Apartheid; e a Resolução 181 (ONU, 1963) pelo Conselho de Segurança, de 7 de agosto de 1963, que obrigava a realização de um embargo de armas contra Pretória (KENKEL, 2012, p.9).

Nesse sentido, o Secretário-Geral, Javier Pérez de Cuellar, no relatório de 1991, destacou os esforços das Nações Unidas em acabar com o regime de segregação e perseguição racial, sustentados por décadas na África do Sul:

It will signify attainment of one of the Organization's major goals when the notable progress made so far is consolidated and a post-apartheid regime based on democratic principles and racial harmony is firmly put in place in that country (ONU, 1991).

O grande movimento dos países africanos rumo à independência se deu em um contexto vantajoso de proliferação de organizações internacionais e não governamentais defensoras dos Direitos Humanos e a incorporação da busca pela paz e defesa da autodeterminação das nações como tema de Fóruns Internacionais (SEITENFUS, et al, 2007, p.9). Dentro deste quadro, “[...] as organizações formais, em particular as Nações Unidas, tiveram um papel significativo no processo de descolonização e de consolidação das normas anticolonialistas [...]" (FINNEMORE, 1996, pp. 174-175 apud KENKEL, 2012, p.9). A incorporação das nações africanas à ONU resultou na prevalência, pela primeira vez, de países "subdesenvolvidos" em seu quadro. Segundo Ricardo Seitenfus, esse novo cenário contribuiu para um substancial redirecionamento da agenda da ONU (SEITENFUS, et al, 2007, p.9).

A Conferência de Bandung, realizada em 18 de abril de 1955, tendo a participação de 29 Estados e 36 convidados (o que representava 60\% da população mundial), conferiu apoio aos territórios afro-asiáticos em processo de descolonização e demonstrou um interesse de seus membros em participar de 
forma mais ativa e propositiva no sistema internacional (SEITENFUS, et al, 2007, p.10). Neste momento, há a valorização do princípio da independência soberana, confirmada com a aprovação da Resolução 1514 (XV), pela Assembleia Geral, em 14 de dezembro de 1960, da Declaração de Garantia de Independência dos Países Coloniais (ONU, 1960), reafirmando que:

O princípio de autodeterminação dos povos; o repúdio a quaisquer tipos de ação armada e medidas de repressão dirigidas contra os povos dependentes; a defesa da integridade territorial destes países; a defesa da não-ingerência nos assuntos internos dos Estados e do respeito aos direitos soberanos de todos os povos; o entendimento de que a falta de preparação no domínio político, econômico, social ou no campo da educação não deveriam servir de pretexto para o retardamento da independência (ONU, 1960 apud SEITENFUS, et al, 2007, p.10, grifos nossos).

ONGs humanitárias como Save the Children, formada ainda na Segunda Guerra, Cooperative for American Relief Everywhere (CARE) e Oxfam, fundada em 1942, foram essenciais para a consolidação de um regime internacional de defesa e promoção dos Direitos Humanos. Uma das ONGs que particularmente influenciou a prática da ONU sobre intervenções humanitárias, foi a Médecins sans Frontières (MSF), criada em 1971, durante a guerra em Biafra, na Nigéria (1967-1970), pelo médico Bernard Kouchner e o jurista francês Mario Bettati. O conceito droit d'ingérence (em português, direito de ingerência) seria lançado por eles um tempo depois e seria fundamental nos debates e nas decisões políticas relacionadas à intervenção humanitária dentro da ONU (EVANS, 2008, pp.3233).

Autor do livro Le droit d'ingérence: mutation de l'ordre internacional, Bettati destaca que a proeminência do conceito se deu especialmente com o fim da Guerra Fria (BETTATI, 1996, p.7 apud KENKEL, 2012, p. 10) por três motivos principais: a emergência de um ambiente de maior cooperação das grandes potências no Conselho de Segurança; o fim das "guerras de procuração" (ou proxy wars, em inglês) no continente africano; e uma melhor aceitação dos direitos humanos pelos Estados receptores de ajuda (BETTATI, 1996 apud KENKEL, 2012, p. 10). Entretanto, Gareth Evans (2008, p.33) ressalta que a expressão francesa transmite uma ideia não apenas de intervenção, mas de interferência, "not in any way acknowledging the anxieties of those in the global South who had all 
too often been the beneficiaries of missions civilisatrices in the past". Por isso, Evans (2008, p.33) ressalta que o conceito droit d'ingérence teve uma receptividade melhor no Norte Global.

\section{Intervenções durante a Guerra Fria}

Nicholas Wheeler (2000) realça que as intervenções humanitárias foram tratadas de formas bastante distintas antes e após a Guerra Fria. De fato, as três intervenções aplicadas durante a Guerra Fria foram feitas à margem do sistema de segurança coletiva, sem aprovação do Conselho de Segurança ou até de organizações regionais.

O primeiro episódio foi a intervenção militar da Índia no Paquistão oriental, em 1971, com o objetivo de combater os assassinatos e perseguições aos bengaleses e garantir a posterior independência de Bangladesh. O governo paquistanês encaminhou a situação para o Conselho de Segurança, que interpretou a ação indiana como uma violação da Carta e demandou o cessar-fogo imediato e a retirada das tropas invasoras (S/RES/307, 1971). O governo indiano alegou resposta a um ataque aéreo iminente do Paquistão, ou seja, uma ação abrangida pela permissão do uso da força em legítima defesa (EVANS, 2008, p.22), conforme o comando do artigo 51 da Carta, analisado anteriormente. A necessidade de a Índia justificar sua ação por outras razões que não a violação dos Direitos Humanos pelo Paquistão mostra a primazia absoluta da soberania tradicional durante esta época.

Os outros dois principais casos de intervenção neste período foram a derrubada do regime de Pol Pot no Camboja pelo exército do Vietnã e a ação militar da Tanzânia, que deu fim ao governo despótico de Idi Amin em Uganda (WHEELER, 2000). No Camboja, o regime de terror do Khmer Vermelho resultou em assassinatos diretos de milhares de cambojanos e mais outros milhares de mortos por desnutrição e doenças, o que causou em torno de dois milhões de vítimas (EVANS, 2008, p.24). A escala do horror era amplamente conhecida na comunidade internacional à época da invasão do Vietnã, o que não foi o suficiente para que o governo vietnamita se livrasse das acusações de desrespeito à Carta das Nações Unidas por violar os direitos soberanos do 
Camboja. Como lembra Evans (2008, p.24), "condemnation was widespread, from the United States, United Kingdom, and their NATO allies; every member state of the Association of Southeast Asian Nations (ASEAN); Australia, most Latin America countries; and many others as well". Isso era um sinal de que naquele momento só o bloco soviético apoiaria as ações humanitárias, uma vez que elas eram percebidas a partir da ótica da disputa entre as duas grandes potências. No caso africano, a Anistia Internacional estimou que pelo menos 100.000 pessoas foram assassinadas sob o regime de Amin (EVANS, 2008, p.24). No entanto, a União Africana não legitimou a ação humanitária, levando o governo da Tanzânia a alegar ataque prévio por parte de Amin.

Nos três casos, apesar de as violações de Direitos Humanos terem sido comprovadas, nenhum dos interventores reforçou o caráter humanitário da ação quando criticados no plano internacional. Na verdade, o que se viu foi um grande silêncio por parte das grandes potências diante das tragédias humanitárias porque a atenção concentrava-se na disputa político-militar. O problema, como sublinha Evans, é que as consequências foram sentidas diante das catástrofes dos anos noventa:

\begin{abstract}
The cynicism of the great powers about human rights violations in their own and each other's backyards was understandable that, for defensive self-interested reasons, sovereignty should have continued to be a very sensitive subject indeed with the many states who gained their independence during the decolonization era. But the trouble with these reactions, like most things taken too far, is that they had a terrible downside, which came to head in the 1990s in the international response to the series of man-made catastrophes that erupted in many parts of the world, but to most deadly effect in the Balkans and Africa (EVANS, 2008, p.25).
\end{abstract}

\title{
Os anos 90 e a nova agenda de segurança da ONU
}

A configuração de uma nova ordem mundial, com o fim da Guerra Fria, vem acompanhada de novos desafios. Só em 1995, os trinta maiores conflitos armados que ocorreram no mundo foram guerras civis (PARIS, 1997, p.55). Isso não significa, porém, que não ocorriam conflitos civis antes disso. Como bem lembrou Celso Amorim em um discurso, é possível voltar até a Revolução Francesa ou ainda mais: "muitos dos conflitos do passado tiveram uma natureza interna que, de uma forma ou outra, tornou-se internacional" (AMORIM, 1998 
apud FONSECA JR (org.), 2002, p.305). A grande questão é que durante a Guerra Fria o foco estava na competição político-militar entre Estados Unidos e União Soviética. O resto do mundo era visto como uma extensão desta disputa central. Neste período, os temas e as experiências dentro do outro segmento, rotulado coletivamente de Terceiro Mundo, não foram totalmente incorporados dentro do discurso político, nem dos principais estudos acadêmicos de segurança (ACHARYA, 1994).

Amitav Acharya (1994) destaca, inclusive, que a maioria dos conflitos ocorridos durante a Guerra Fria no Terceiro Mundo era justamente de natureza intraestatal, como insurreições antirregime, guerras civis, conflitos tribais; e que os chamados conflitos regionais ao longo deste período foram essencialmente domésticos em origem. Aliás, o autor também destaca que a busca por influência das superpotências contribuiu significativamente para fomentar e prolongar muitos casos conflituosos incipientes e latentes no Terceiro Mundo (ACHARYA, 1994), cujas consequências ainda são visíveis, como no caso do conflito em Angola.

Por isso, dizer que as guerras do pós-Guerra Fria são novas ${ }^{\mathbf{1 0}}$ significa conceber a história de forma linear. De fato, com a desintegração da União Soviética e a eclosão de uma série de movimentos de independência, muitos conflitos étnicos surgem especialmente na região dos Balcãs. Tais conflitos devem ser entendidos como frutos de um contexto histórico específico e não como inauguração de uma era totalmente nova. Da mesma forma, é importante observar que muitos conflitos tratados ainda hoje são entre Estados, como a questão do Oriente Médio (FONSECA JR (org.), 2002, pp.305-306).

O fim da bipolaridade também ofereceu uma oportunidade para o aperfeiçoamento da cooperação multilateral, principalmente no campo da segurança e, inclusive, dentro do Conselho. Bettati (1996) sinaliza que isso se traduz em uma conexão mais clara entre direitos humanos e manutenção da paz, resultando em uma orientação mais assertiva sobre as responsabilidades dos Estados e uma percepção cada vez mais flexível do princípio de soberania como um direito absoluto. O Relatório, de 1991, do Secretário-Geral, Javier Pérez de Cuellar, é bastante indicativo dessas mudanças:

\footnotetext{
${ }^{10}$ Referência à ideia de "novas guerras" desenvolvida por Mary KALDOR (2001). A autora
} relaciona as chamadas "novas guerras" aos processos de globalização. 
[...] o encorajamento do respeito pelos Direitos Humanos se torna um argumento vácuo se os erros humanos cometidos em grande escala enfrentam unicamente a ausência de ação rápida e adequada por parte das Nações Unidas. Promover os Direitos Humanos pouco quer dizer se não significa defendê-los quando mais estão sob ataque.

Eu acredito que a proteção dos Direitos Humanos virou uma das pedras basilares no arco da paz. Também estou convencido que envolve agora uma aplicação mais concertada da influência e da pressão internacional através de apelos, admonições, argumentação, ou condenação e, em última instância, uma presença apropriada das Nações Unidas, do que antigamente era visto como permissível sob o direito internacional tradicional.

Agora, estima-se crescentemente que o princípio da não interferência na jurisdição doméstica essencial dos Estados não pode ser visto como uma barreira protetora atrás da qual podem-se violar maciça e sistematicamente os Direitos Humanos com impunidade. [...] As omissões ou fracassos devidos a várias circunstâncias contingentes não constituem um precedente [...]. Com o crescimento do interesse internacional na universalização de um regime de Direitos Humanos, veio uma marcante e muito bem-vinda mudança nas atitudes públicas. Tentar resistir seria em igual medida politicamente imprudente e moralmente indefensível (ONU, 1991, tradução de Kai KENKEL, grifos nossos).

O documento do Secretário-Geral, Pérez de Cuellar, foi publicado no ano seguinte à adoção do conceito de desenvolvimento humano sustentável pelo Relatório de Desenvolvimento Humano do Programa das Nações Unidas para o Desenvolvimento (PNUD), publicado anualmente desde então. O conceito está diretamente ligado com o esforço da organização pela institucionalização da promoção e defesa dos direitos humanos como uma prática internacional. ${ }^{11}$ Segundo o Relatório, desenvolvimento humano pode ser definido como:

[...] a process of enlarging people's choices. In principle, these choices can be infinite and change over time. But at all levels of development, the three essential ones are for people to lead a long and healthy life, to acquire knowledge and to have access to resources needed for a decent standard of living. If these essential choices are not available, many other opportunities remain inaccessible. But human development does not end there. Additional choices, highly valued by many people, range from political, economic and social freedom to opportunities for being creative and productive, and enjoying personal self-respect and guaranteed human rights (PNUD, 1990, grifos nossos).

\footnotetext{
${ }^{11}$ Vale lembrar que a década de noventa também foi o momento em que a ONU experimentou novas iniciativas e teve um maior envolvimento da sociedade civil em suas atividades. Avanços importantes nessa direção ocorreram nesse período: como a Cúpula das Nações Unidas para Meio Ambiente e Desenvolvimento (ou ECO-92 ou Earth Summit), no Rio de Janeiro; a Conferência de Direitos Humanos em Viena, em 1993 (quando foi determinada a criação do cargo de Alto Comissário para os Direitos Humanos); a Conferência sobre População, no Cairo (1994); sobre Desenvolvimento Social, em Copenhague (1995); e a Conferência da Mulher (1995), em Pequim.
} 
O Relatório também afirma que o desenvolvimento humano precisa ser conquistado com bases para o futuro, ou seja, de uma forma sustentável. Esta menção está relacionada com a preservação e regeneração do meio ambiente (PNUD, 1994, p.13), assim como com a ideia de que o desenvolvimento é a fonte para uma paz durável. Dessa forma, a ONU confirma uma mudança na percepção do significado de desenvolvimento defendendo que os Estados devem considerar o bem-estar das pessoas, incluindo a preocupação com o meio ambiente, como propósito final das políticas públicas - e não a acumulação de riquezas. ${ }^{12}$

Claro que crescimento econômico continua sendo um fator importante, mas deve ser um meio para melhorar a vida das pessoas e não o fim último das atividades. Por isso, o Relatório propôs um índice para medir o desempenho nacional em desenvolvimento humano ${ }^{\mathbf{1 3}}$ - o IDH (Índice de Desenvolvimento Humano) - que envolve "a systematic examination of a wealth of information about how human beings in each society live (including their state of education and health care, among other variables)" (SEN, 2000, p.18). Segundo MacFarlane e Khong (2006), apesar de as variáveis escolhidas e os métodos utilizados para medir o IDH terem sido alvo de debates, ${ }^{14}$ o índice trouxe de vez o tema do desenvolvimento humano para a agenda principal dos países. O IDH passa a ser o principal indicador do nível de desenvolvimento de uma nação e não mais o produto interno bruto (PIB). Afinal, "it is by now widely understood that there is no one-to-one correspondence between material enrichment (measured, say, by, GNP per capita) and the enrichment of human lives (measured, say, by the human development index)" (MACFARLANE; KHONG, 2006, p.145).

Em 1994, no Relatório "Uma Agenda para o desenvolvimento" (ONU, 1994), encaminhado pelo Secretário egípcio Boutros Boutros-Ghali (1992-1996) à Assembleia Geral, desenvolvimento é apresentado como um conceito amplo e plural, que envolve uma série de dimensões inter-relacionadas e uma multiplicidade de atores (ONU, 1994, §210). Por isso, a primeira parte do Relatório é dividida a partir das cinco principais dimensões do desenvolvimento:

\footnotetext{
${ }^{12}$ Cf. site do PNUD Brasil. Disponível em: <http://www.pnud.org.br/home/ > Acesso em: 10 de janeiro de 2012.

${ }^{13} \mathrm{O}$ IDH foi criado pelo professor Amartya Sen, ganhador do Prêmio Nobel de Economia em 1998.

${ }^{14}$ Atualmente, o IDH é medido a partir de três dimensões básicas do desenvolvimento humano: uma vida longa e saudável, acesso ao conhecimento e um padrão decente de vida. Disponível em:<http://www.onu.org.br/rdh2011/>. Acesso em: 14 de fevereiro de 2012.
} 
"paz como fundação; economia como motor do progresso; meio ambiente como base para a sustentabilidade; justiça como um pilar da sociedade; e democracia como boa governança" (ONU, 1994, tradução nossa). Nenhuma dimensão poderia ser excluída do processo de desenvolvimento ou tratada de forma isolada, pois,

without peace, human energies cannot be productively employed over time. Without economic growth, there will be a lack of resources to apply to any problem. Without a healthy environment, productivity will devour the basis of human progress. Without societal justice, inequalities will consume the best efforts at positive change." Without political participation in freedom, people will have no voice in shaping their individual and common destiny (ONU, 1994, $\S 211$, grifos nossos).

Um movimento importante realizado no documento é a articulação discursiva entre segurança e desenvolvimento. Desenvolvimento é apresentado como um direito humano e como "the most secure basis for peace" (ONU, 1994, $\S 3)$. Isso porque "the lack of development contributes to international tension and to a perceived need for military power. This in turn heightens tensions. Societies caught in this cycle find it difficult to avoid involvement in confrontation, conflict or all-out warfare" (ONU, 1994, § 18). Da mesma forma, o Relatório enfatiza que um ambiente de segurança e estabilidade é fundamental para o processo de desenvolvimento humano. Ou seja,"without peace, there may be no development. But without development, peace may be threatened" (PNUD, 1994, p.13).

Essa concepção muda completamente as prioridades da agenda de segurança, assim como suas estratégias de execução. As principais fontes de insegurança passam a estar relacionadas com fatores domésticos - que podem gerar consequências globais. Por isso, conflitos civis, pobreza, desemprego, falta de liberdade de expressão e representação política não são vistos apenas como problemas internos de um país, mas como problemas pertencentes a toda comunidade global, uma vez que a segurança internacional passa a estar em jogo. Principalmente porque tais fatores geram instabilidade social e consequências que transcendem fronteiras: como degradação ambiental, tráfico de armas e de drogas, comércio ilegal, migração massiva, pirataria, aumento da violência e terrorismo. Em resumo, o conceito de segurança global passa a abranger não só a tradicional segurança dos Estados, como também à do meio ambiente, e principalmente, a 
segurança das pessoas. Já não é, portanto, "a concern with weapons it is a concern with human life and dignity" (PNUD, 1994, p.13).

Segundo a ONU, subdesenvolvimento é, ao mesmo tempo, fonte e consequência dos conflitos, tornando-se necessário combatê-lo para assegurar a paz e a segurança internacionais, conforme afirmou Boutros Boutros-Ghali nos parágrafo 13 e 55 de "Uma Agenda para a Paz":

Poverty, disease, famine, oppression and despair abound, joining to produce 17 million refugees, 20 million displaced persons and massive migrations of peoples within and beyond national borders. These are both sources and consequences of conflict that require the ceaseless attention and the highest priority in the efforts of the United Nations. A porous ozone shield could pose a greater threat to an exposed population than a hostile army. Drought and disease can decimate no less mercilessly than the weapons of war. So at this moment of renewed opportunity, the efforts of the Organization to build peace, stability and security must encompass matters beyond military threats in order to break the fetters of strife and warfare that have characterized the past. But armed conflicts today, as they have throughout history, continue to bring fear and horror to humanity, requiring our urgent involvement to try to prevent, contain and bring them to an end (ONU, 1992, § 13, grifos nossos).

Dessa forma, as operações de paz passam a incluir tarefas relacionadas ao desenvolvimento, denominadas de peacebuilding (atividades de consolidação da paz), ${ }^{\mathbf{1 5}}$ com o objetivo de fortalecer os Estados pós-conflito de forma sustentável. Em "Uma Agenda para o desenvolvimento", Boutros Boutros-Ghali define:

Peace-building means action to identify and support structures which will tend to strengthen and solidify peace in order to avoid a relapse into conflict. As preventive diplomacy aims to prevent the outbreak of a conflict, peacebuilding starts during the course of a conflict to prevent its recurrence. Only sustained, cooperative work on the underlying economic, social, cultural and humanitarian problems can place an achieved peace on a_durable foundation. Unless there is reconstruction and development in the aftermath of conflict, there can be little expectation that peace will endure (ONU, 1994, §22, grifos nossos).

A prática de peacebuilding surge para complementar três outras ações: preventive diplomacy (diplomacia preventiva); peacemaking (estabelecimento da

\footnotetext{
${ }^{15}$ Tradução de peacebuilding por Gilda Motta Santos NEVES (2009).
} 
paz); e peacekeeping (operações de manutenção da paz [OMP]). ${ }^{\mathbf{1 6}}$ Assim, as atividades de desenvolvimento são colocadas em prática quando as três etapas anteriores foram bem-sucedidas. Em "Uma Agenda para a paz", cada uma das ações (preventive diplomacy, peacemaking, peacekeeping e peacebuilding) corresponde a um dos objetivos da atuação da ONU, respectivamente: (i) identificar, o mais cedo possível, situações potencialmente conflituosas e neutralizá-las, por meio da diplomacia preventiva, antes que resultem em violência; (ii) uma vez iniciado o conflito, engajar-se em interrompê-lo e buscar soluções para suas causas, o que seria feito via peacemaking; (iii) com o peacekeeping (OMP), trabalhar para preservar a paz e assistir a implementação de acordos onde as batalhas tiverem sido suspensas; e (iv) assistir a reconstrução das instituições e da infraestrutura dos Estados afetados pela guerra e construir laços pacíficos e mutuamente benéficos entre países, por meio do peacebuilding pósconflito. (ONU, 1992, § 15, tradução de Letícia SOUZA).

É possível identificar que há uma lógica sequencial nas atividades previstas. As ações de peacebuilding são admitidas apenas para situações pósconflito, o que gerou uma série de críticas, inclusive do Brasil, resultando na revisão deste ponto no documento publicado em 1995, intitulado Supplement to an Agenda for Peace ("position paper"). Nele, o Secretário-Geral tem o cuidado de admitir as atividades de desenvolvimento em situação de pré-conflito, durante o conflito e pós-conflito, com ou sem a existência de operação de manutenção da paz no terreno.

Também é importante observar o fato de que passa a haver uma confusão cada vez maior entre o estabelecimento da paz, ou peacemaking, e a manutenção da paz, ou peacekeeping. Boutros Boutros-Ghali redefine os parâmetros tradicionais de atuação das operações de paz ao estabelecer que "peacekeeping is the deployment of a United Nations presence in the field, hitherto with the consente of all the parties concerned" (ONU, 1995). Desse modo, o Secretário sinaliza a possibilidade da existência de operações de paz sem o consentimento

\footnotetext{
${ }^{16}$ Peacemaking seria a fase seguinte da diplomacia preventiva, quando a Organização precisaria engajar-se na chamada solução pacífica de controvérsias, incluindo mediação, negociação, conciliação e arbitragem, após a eclosão do conflito (NEVES, 2009, p. 16). Peace-enforcement ou imposição da paz é uma forma de estabelecer a paz através da força militar. Essa ação é citada na Doutrina Capstone, em 2008. As intervenções humanitárias são aprovadas sob o Capítulo VII, na condição de uma ação de imposição da paz.
} 
local, em certas situações (RUGGIE, 1996, p.5 apud PATRIOTA, 1998, p.57). Neste ponto, vale retomar a discussão feita anteriormente sobre o pressuposto do consentimento. O texto quando diz "all the parties concerned" não deixa claro quais são as partes envolvidas, o que pode levar a múltiplas interpretações quando se trata de conflitos intraestatais.

Vale dizer, no entanto, que o documento publicado em 1995 reforça a relevância do consentimento das partes para a presença e o mandato das operações de manutenção da paz. Nesse contexto, as operações de paz passam a ter um caráter multidimensional (WEISS; FORSYTHE; COATE, 2004). A Doutrina Capstone (Capstone Doctrine), de março de 2008, consolida as orientações normativas, institucionais e operacionais das novas missões. De acordo com o documento, o processo de paz poderia ser dividido em três grandes fases: estabilização; consolidação da paz; e recuperação e desenvolvimento a longo prazo.

Outra parte interessante da Agenda para a paz é que ela indica uma mudança essencial na interpretação do princípio da soberania. No famoso parágrafo 17, o Secretário afirma textualmente que "the time of absolute and exclusive sovereignty, however, has passed" (ONU, 1992). É possível compreender este movimento como um dos resultados da incorporação para a agenda de segurança de preocupações ligadas a direitos humanos, problemas humanitários, a proteção da ordem democrática, terrorismo e a não proliferação (PATRIOTA, 1998, p.168). O campo de ação do Conselho de Segurança é, de certo modo, redefinido (PATRIOTA, 1998, p.168). Segundo Patriota,

O Capítulo VII foi posto a serviço de uma concepção de paz e segurança internacionais menos tolerante em face da invocação de preceitos como o da igualdade soberana dos estados ou o da não ingerência nos assuntos internos, sobretudo, quando levantados como escudo para justificar atos de violência do estado contra o indivíduo, para acobertar o terrorismo, para promover o armamentismo agressivo, para perpetuar formas flagrantes de injustiça (PATRIOTA, 1998, p.168).

Para Weiss e Gordenker, configura-se, então, "a novel form of collective responses akin to collective security but not easily contained in the original approach" (WEISS; GORDENKER, 1993, p.214 apud PATRIOTA, 1998, p.168). O Capítulo VII da Agenda para a Paz, que aborda o tema “cooperação com 
arranjos e organizações regionais" também sinaliza uma dilatação no entendimento sobre o que define um organismo regional. No parágrafo 61, o Secretário lembra que a Carta não oferece nenhuma definição precisa de arranjos regionais e agências. Isso estimulava o desenvolvimento de esforços complementares entre a ONU e esses grupos, permitindo que "associations or entities could include treaty-based organizations, whether created before or after the founding of the United Nations, regional organizations for mutual security and defence, organizations for general regional development [...]" (ONU, 1992, $\S 61)$ fossem aceitas como organismos regionais em sentido amplo.

Ou seja, isso permite que alianças como a da OTAN, criada com base no artigo 51 da Carta da ONU (1945), que dispõe sobre a legítima defesa, fossem tratadas como organismos, com amparo no Capítulo VIII da Carta ("Acordos Regionais"), que previa no artigo 53, $\S 1^{\circ}$ que: "O Conselho de Segurança utilizará, quando for o caso, tais acordos e entidades regionais para uma ação coercitiva sob a sua própria autoridade [...]". O objetivo, assim, parecia ser o de estender as possibilidades de cooperação da ONU para ações sob o Capítulo VII, o que indicava o início da normalização da relação entre a ONU e as alianças defensivas, em especial a OTAN (PATRIOTA, 1998, p.59).

\section{O conceito de Segurança Humana}

Os Relatórios de Desenvolvimento Humano produzidos, em 1993 e 1994, estabelecem, pela primeira vez, o nexo discursivo entre desenvolvimento e segurança através do conceito de segurança humana. Assim como o conceito de desenvolvimento sustentável, segurança humana pode ser considerado um conceito singular coletivo (KOSELLECK, 2006) por incluir diversas áreas e temas em uma única abordagem: como segurança econômica, segurança alimentar, segurança de saúde, segurança do meio ambiente, segurança pessoal, segurança da comunidade e segurança política. O conceito de segurança humana significa criar condições mínimas para que as pessoas possam exercer de forma segura e livre suas escolhas; "that they can be relatively confident that the opportunities they have today are not totally lost tomorrow" (PNUD, 1994). A ONU define que segurança humana: 
Em sua forma mais ampla, engloba muito mais que a ausência de conflitos violentos. Inclui direitos humanos, boa governança, acesso à educação e à saúde e a garantia de que cada indivíduo tenha oportunidades e escolhas que proporcionem a realização de todo o seu potencial. Cada passo nessa direção é também um passo rumo à redução da pobreza, ao crescimento econômico e à prevenção de conflitos. (CSH, 2003, p.4, tradução Letícia SOUZA)

Segurança simboliza a proteção "from the threat of disease, hunger, unemployment, crime, social conflict, political repression and environmental hazards" (PNUD, 1994, p.22). E para proteção das novas ameaças, que estão muito mais relacionadas com perigos cotidianos do que grandes ofensivas estatais, o desenvolvimento se torna uma peça-chave. Por isso, a apropriação do conceito de segurança humana teve um impacto direto no campo das operações de paz. A atenção se direciona para a busca pela recolocação dos países em situação de pósconflito em conformidade com os princípios da governança global, baseados na democracia liberal. Aos poucos, a cultura de reação vai dando lugar à cultura de prevenção.

Desenvolvimento passa a ser um elemento essencial para a prevenção de conflitos e para o alcance da paz a longo prazo. Por isso, as tarefas de peacebuilding passam a ser fundamentais nos mandatos das operações. Nessa linha, um ambiente seguro é condição necessária para a execução das atividades de reconstrução. Portanto, o conceito de desenvolvimento é entendido pela ótica da segurança.

$\mathrm{O}$ conceito de segurança humana articula três elementos cruciais. O primeiro está relacionado à defesa do Estado de Direito ou rule of law, ancorados nos princípios liberais de direitos individuais básicos da "vida, liberdade, e a busca de felicidade" (HAMPSON, 2008, p.230). Isso leva à obrigação de a comunidade internacional proteger e promover tais direitos. O segundo está diretamente envolvido com o primeiro e se refere à intervenção humanitária, que "informs international efforts to deepen and strengthen international law, particularly regarding genocide and war crimes, and to abolish weapons that are especially harmful to civilians and non-combatants" (HAMPSON, 2008, p.230). E o terceiro elemento está relacionado às tarefas de peacebuilding, "which suggests that human security should be widely constructed to include economic, environmental, social and other forms of harm to the overall livelihood and wellbeing of individuals" (HAMPSON, 2008, p.231). 
A articulação desses três elementos - que se desdobra no conceito de segurança humana - possibilitou que se interpretassem as situações de crise humanitária como um problema de segurança internacional. Nesse sentido, a construção de um nexo discursivo entre segurança e humanitarismo e entre segurança e desenvolvimento passa a legitimar e orientar a prática das operações de paz como um todo a partir dos anos noventa. Pode-se dizer, portanto, que é a partir do conceito de segurança humana que se desdobram duas práticas transversais: intervenção humanitária e peacebuilding.

Importante destacar que a ONU não é só um espaço social ou "a arena mais universal para negociação de normas internacionais", mas é também "um ator, assumindo posições e produzindo ideias dentro dos limites estabelecidos por Estados que a constituíram" (HERZ; HOFFMANN, 2004, p.98). O conceito de segurança humana não apenas indica uma mudança na agenda de segurança, como também constrói essa nova realidade. Por isso, pensar as condições de produção desse conceito ajuda a não naturalizar os discursos dominantes, e, sobretudo, a reconhecer que "any reality is mediated by a mode of representation and that representations are not descriptions of a world of facticity, but are ways of making facticity" (DER DERIAN; SHAPIRO, 1989, pp. 13-14).

Desse modo, o entendimento da ONU que subdesenvolvimento e crises humanitárias são problemas prioritariamente do campo da segurança tem um impacto direto no modo de conduta dos Estados, das pessoas, e nas políticas formuladas. Mas esse entendimento é também fruto de um processo histórico em que a cultura política do Norte Global sempre foi predominante. Isto significa reconhecer que há uma relação assimétrica entre os países e, por consequência, na produção "of subjects, acts and themes through which the political world is constructed" (DER DERIAN; SHAPIRO, 1989, pp. 13-14). Amitav Acharya (1994) destaca que há uma consistente tentativa pelos atores do Norte Global (durante e após a Guerra Fria) - em gerenciar a ordem internacional de uma forma que geralmente não é compatível com as realidades regionais no Terceiro Mundo. Ao contrário, tal tentativa tem contribuído para um clima de desconfiança e de tensão entre Norte-Sul em temas sobre a governança global (ACHARYA, 1994, p.14). 


\section{Subdesenvolvimento como um problema de segurança}

Como vimos, o subdesenvolvimento passa a ser visto como um problema de segurança. Uma ameaça ao sistema internacional. Esse processo faz parte de um movimento de redefinição e extensão do conceito de segurança nos anos noventa. A Escola de Copenhagen - representada pelos autores Buzan, Waever e Wilde (1998) - foi um movimento que acompanhou esse processo de ampliação da agenda de segurança já a partir dos anos 80 . Os autores mostram que é preciso pensar em outras fontes de ameaça para além da militar, como a política, a econômica, a social e a ambiental e em novos objetos de referência (relativos à sobrevivência) além do Estado, como os indivíduos e a sociedade internacional. Sem entrar em detalhes sobre os estudos da Escola de Copenhagen, vale a pena trazer o pensamento de um de seus críticos para ajudar na problematização deste tema.

Didier Bigo (2007, 2008, 2008a, 2009) entende que segurança está relacionada também e, principalmente, com sacrifício, com exclusão. Isso tem um enorme impacto, por exemplo, na forma como as relações humanas se estabelecem e, especialmente no caso em questão, em como se dá a relação entre as tropas da ONU e a população local de países em conflito ou em pós-conflito. Nesse sentido, entender o subdesenvolvimento como uma questão de segurança contribui para solidificar uma perspectiva sobre o Sul Global como um lugar ameaçador. Condenam-se as pessoas que vivem nessa parte do globo para salvar outras, incluídas no projeto liberal. Para Bigo, isso constitui uma lógica de banoptico em contraposição ao pan-optico. Pan-optico seria a vigilância de todos, enquanto ban-optico refere-se à vigilância de alguns para segurança da maioria. Ou seja, a necessidade de vigilância, violência, punição, ou transformação de alguns para a segurança de maior parte da população. A segurança de alguns cria a insegurança de outros. Cria-se uma lógica preventiva.

O autor também alerta que isso faz com que incorporemos essas exclusões como normais. Elas entram na rotina e não são mais colocadas no debate político. Não são mais abertas à negociação. As identidades são reificadas de uma forma monolítica e as práticas do dia a dia não abrem oportunidades para se pensar sobre alternativas. Nesse sentido, Fierke (2007, p.15) lembra que "security is always political, defined in historical context and redefined as contexts change". 
Securitizar o tema do subdesenvolvimento faz parte de um contexto de governança global em que se busca a preservação de uma lógica democráticaliberal.

Bigo defende a ideia de que as práticas diárias alimentam este processo de exclusão. Não há uma intenção e os resultados não são previstos. É uma mistura de interesses de diferentes setores da sociedade e a sua aceitação que alimentam esta rotina. Por exemplo, empresas que vendem produtos de segurança, o que justifica a inovação de tecnologias, pois é preciso ter gente para comprar; os setores de inteligência dos Estados; os funcionários de migração que veem naquilo sua fonte de vida, patrulhas de fronteiras, exército, jornalistas que ganham dinheiro com as notícias, etc.

No contexto atual, a pobreza e a ausência de democracia tipificam espaços como inseguros e ameaçadores. Simultaneamente, os indivíduos que ocupam esses espaços são percebidos da mesma forma: como inimigos ou potenciais inimigos que precisam, ou ser combatidos, ou transformados em "ocidentais". Mark Duffield (2001) afirma que as atividades de peacebuilding têm justamente a função de transformar as sociedades - substituindo os valores e modos de organização tradicionais pelos liberais. Esta passa a ser condição fundamental para o estabelecimento de um tipo específico de paz: a paz liberal. É o que o autor chama de radicalização do desenvolvimento. Nesse sentido, "the aim of liberal peace is to transform the dysfunctional and war-affected societies that it encounters on its borders into cooperative, representative and, especially, stable entities" (DUFFIELD, 2001, p.11). Essa é a garantia última para a manutenção da paz e da segurança no sistema internacional.

\section{A Intervenção Humanitária nos anos 90}

Os anos noventa foram marcados por uma progressão de mandatos do Conselho de Segurança. Ao longo desta década, nove operações militares foram consideradas pelo Conselho simultaneamente humanitárias e coercitivas. Em cada caso, as intervenções ocorreram tanto expressamente contra a vontade dos governos (como no Norte do Iraque, na Bósnia e em Ruanda) ou em circunstâncias onde a questão do consentimento era irrelevante (porque nenhum 
governo existia, como na Somália), ou de forma controversa (normalmente pela ausência de um controle real do regime, como na Libéria, Haiti e Serra Leoa), ou ambígua (como no Timor-Leste, onde o consentimento foi dado sob uma imensa pressão internacional e pelas autoridades indonésias - consideradas em ocupação ilegal) (EVANS, 2008, pp. 25-26, tradução nossa).

A intervenção na Libéria foi realizada por uma organização sub-regional africana - a Comunidade Econômica dos Estados da África Ocidental (Economic Community of West African States [ECOWAS]), agindo com a aprovação do Conselho de Segurança, embora cinco meses depois do início da guerra civil, com o envio de uma força de paz liderada pela Nigéria, em 1990, a ECOMOG (ECOWAS Cease-fire Monitoring Group), com o objetivo de parar o conflito. No Norte do Iraque, em 1991, em sequência da Guerra do Golfo e em resposta à campanha de repressão de Saddam Hussein contra os curdos, os Estados Unidos e seus aliados criaram zonas de segurança, se baseando na autoridade de uma resolução anterior, o que foi uma ação vista como controversa (EVANS, 2008, pp. 25-26). Em 1994, o Conselho de Segurança autorizou uma força multinacional no Haiti, através da Resolução 940 (ONU, 1994a), para a recolocação do presidente Aristide, após este ter sido deposto por um golpe de Estado promovido por militares poucos meses depois de ter tomado posse, em 1991. A deposição de Aristide levou à entrada de 42 mil haitianos em solo americano, o que certamente motivou os Estados Unidos ao esforço de reconduzir Aristide à presidência (FILHO, 2007, p.146).

Em Serra Leoa, em 1997, houve outra intervenção pela ECOWAS, liderada pela Nigéria - de novo com uma aprovação posterior do Conselho de Segurança - para restaurar a ordem constitucional depois de um golpe e prevenir a emergência de um conflito violento. Mas a ECOWAS não conseguiu conter a violência como era esperado, assim como as missões da ONU sucessoras, cujas tropas foram comumente vistas como pobremente armadas, indisciplinadas e ineficientes. A quinta operação se deu no Timor-Leste, em 1999, depois do patrocínio da Indonésia ao conflito armado, após o resultado do referendum ter sido pró-independência do Timor. Uma resolução do Conselho de Segurança autorizou uma força multilateral sob a liderança australiana para restaurar a paz e a segurança (KALDOR, 2007; WHEELER, 2000). 
Seguindo o argumento do Relatório da ICISS, os casos da Somália, Ruanda, Bósnia, e Kosovo merecem uma descrição um pouco maior por terem provocado um impacto direto na forma como o problema da intervenção humanitária é visto, analisado e caracterizado (ICISS, 2001, p.1).

\section{Somália}

A Somália entrou em processo de guerra civil após a queda de Mohammed Siad Barré, em janeiro de 1991. A catástrofe humanitária que se seguiu levou à aprovação da Resolução 794 (ONU, 1992a), de 3 de dezembro de 1992, que tinha como objetivo principal dar assistência a uma população de quase dois milhões de pessoas ameaçadas pela miséria e violência. A justificativa para a intervenção manteve o foco nas razões humanitárias e não nos cálculos geoestratégicos, o que, segundo Wheeler (2000, p.183), sinalizou um importante avanço no tema. Contudo, o autor alerta que a intervenção militar foi justificada pelos membros do Conselho como sendo uma situação especial, única, e que isso não significava a abertura de um precedente. Esse cuidado se deu principalmente em resposta às preocupações da China, Índia, Brasil, entre outros países que viam com desconfiança a possibilidade da violação do direito de soberania (WHEELER, 2004, p.36 apud KENKEL, 2012, p.13). Por esse motivo, foram incluídas as palavras "unique", "extraordinary" e "exceptional" na resolução e foi argumentado "que uma ação do Conselho de Segurança só foi possível porque não existia nenhum governo [...]” (WHEELER, 2000, p. 186, tradução Kai KENKEL). Dessa forma, "os Estados que mais temiam o enfraquecimento da interpretação pluralista da regra da soberania podiam racionar que nenhum tal precedente tinha sido estabelecido" (WHEELER, 2000, p. 186, tradução Kai KENKEL).

A operação foi bem-sucedida em um primeiro momento, mas como alertou Evans, a tentativa equivocada de travar guerras contra líderes milicianos resultou no desastre conhecido nos Estados Unidos como "Black Hawk Down", em Mogadício, em outubro de 1993, quando 18 norte-americanos morreram. Depois desse episódio, as tropas americanas saíram do país e a missão da ONU foi retirada em abril de 1995, com a maioria dos objetivos inalcançados e uma sensação desagradável sobre a experiência de intervenção humanitária, o que viria influenciar as futuras ações (EVANS, 2008, p.27). 
Muitos críticos, até mesmo antes desse episódio, argumentavam que os nacionais deviam ser privilegiados em relação aos estrangeiros e que a função do Estado é proteger seus nacionais e não outros. Samuel Huntington, por exemplo, escreveu que é "morally unjustifiable and politically indefensible that members of the armed forces should be killed to prevent Somalis from fighting one another" (WEISS, 1999, p.90 apud KALDOR, 2007, p.56). Richard Goldstone descreveu uma conversa com Edward Heath logo após ser nomeado Procurador-Chefe para os Tribunais de Ruanda e Iugoslávia:

\begin{abstract}
'Why did you accept such a ridiculous job?' Heath asked me in a friendly tone. I told him that I thought prosecuting war criminals was important, especially given the magnitude of the crimes committed in Bosnia. Heath replied to the effect that if people wished to murder one another, as long as they did not do so in his country, it was not his concern and should not be the concern of British government. At the time, his opinion startled me. Little did I realize that he was candidly stating what many leading politicians in major Western countries were saying privately - and what many of them believe (GOLDSTONE, 2000, p.74 apud KALDOR, 2007, p.56, grifo nosso).
\end{abstract}

Além disso, o caso da Somália levantou o debate sobre os estados "falidos", estimulando ideias como a de reformulação do sistema de tutela da ONU para lidar com situações similares (PATRIOTA, 1998, p.81). Um Seminário organizado pela Unidade de Lições Aprendidas do Departamento de Operações de Paz, após a saída da ONU da Somália, revelou que diferentes conclusões haviam sido tiradas sobre a experiência do uso da força naquele cenário. Três opiniões principais foram identificadas:

a) alguns participantes consideram que, desde que haja consentimento das partes $^{17}$ no nível estratégico, a força, empregada taticamente, pode ser uma ferramenta importante para o trabalho de manutenção da paz da ONU; b) um outro grupo considerou que a manutenção da paz ("peacekeeping") é incompatível com a coerção ("enforcement"), e os dois não podem funcionar simultaneamente; c) uma terceira corrente foi de opinião que não se pode generalizar e cada situação exige um tratamento especial (PATRIOTA, 1998, pp.79-80, grifos nossos)

Naquele momento, inclusive, foi levantada a dúvida se as Nações Unidas estavam realmente preparadas para uma missão de imposição da paz naquela

\footnotetext{
${ }^{17}$ Voltando à discussão do início do capítulo, aqui, por exemplo, não fica claro quais são as partes beligerantes.
} 
proporção: "the United Nations is not yet capable of launching a large-scale enforcement action" (PATRIOTA, 1998, p. 80). A experiência na Somália criou uma desconfiança entre setores do Congresso e da Imprensa, que entendiam que os embaraços sofridos pelos EUA na Somália deviam ser imputados à ONU (PATRIOTA, 1998, pp. 80-81).

\section{Ruanda}

O episódio ocorrido em Mogadício é crucial para explicar a relutância das principais potências, particularmente os Estados Unidos, em responder de forma imediata ao genocídio ruandês, em abril de 1994 (EVANS, 2008, p.27). Após a derrubada do avião do presidente Juvenal Habyarimana, em 6 de abril, a violência tomou conta do país. O general canadense Romeo Dallaire, que comandou a pequena missão de peacekeeping instalada em Ruanda um ano antes (mandato sob o Capítulo VI), a United Nations Assistance Mission in Rwanda (UNAMIR), para monitorar acordos recentes de paz, fez apelos prévios em favor de uma resolução preventiva.

Mas ele foi ignorado. A Bélgica retirou todo seu contingente, e o Conselho de Segurança, ainda sob o impacto das perdas dos soldados (em especial, norteamericanos) na Somália, acabou por, no momento inicial, diminuir as tropas que já estavam no terreno. Infelizmente, quando as tropas francesas chegaram, no final de junho, com o mandato sob o Capítulo VII, mais de 800.000 assassinatos contra os tutsis e hutus moderados já tinham ocorrido em menos de quatro meses (EVANS, 2008, pp.27-28).

Segundo Kai Kenkel, a posterior aprovação do Conselho de Segurança do mandato de peace-enforcement foi marcada por reais esforços em associar diretamente a resposta da ONU a uma crise à Convenção sobre o Genocídio, o que o autor salienta ter sido um passo importante na codificação do direito humanitário. A Convenção define o crime como sendo o "ato cometido com a intenção de destruir em sua totalidade ou em parte um grupo nacional, étnico, racial ou religioso" (PATRIOTA, 2008, p.112). O Artigo VIII da mesma Convenção estabelece que qualquer parte contratante poderá instar os "órgãos competentes das Nações Unidas a tomar as medidas julgadas apropriadas para, de 
acordo com a Carta, prevenir e suprimir os atos de genocídio enumerados no Artigo III" (PATRIOTA, 2008, p.112).

\section{Bósnia}

A desintegração da antiga Iugoslávia ocupou o Conselho de Segurança desde o fim da Guerra Fria. Segundo Evans, a "missão central e mais problemática dos anos noventa foi a UN Protection Force (UNPROFOR), incialmente estabelecida no começo de 1992 como uma operação de peacekeeping com o consentimento da Antiga República da Iugoslávia e outros governos" (EVANS, 2008, pp. 28-29, tradução nossa) ${ }^{18}$ Com a piora da situação, o mandato da UNPROFOR foi estendido para incluir operações de segurança mais robustas, proteção de profissionais de assistência humanitária e comboios na Croácia e na Bósnia, e, em maio de 1993, a proteção de zonas de segurança em torno de Saravejo e cinco cidades Bósnias, incluindo Srebrenica. Em julho de 1995, o General Ratko Mladic dos sérvios da Bósnia comandou a tomada de Srebrenica, até então sob a limitada proteção dos soldados holandeses da UNPROFOR, e foi responsável pela morte de oito mil jovens muçulmanos na cidade. Este foi considerado o maior assassinato em massa na Europa desde a Segunda Guerra Mundial (EVANS, 2008, pp. 28-29). O papel das Nações Unidas foi objeto de crítica por parte da comunidade internacional pelas falhas na atuação da força de paz, incluindo as dificuldades para aprovação de resoluções. Segundo Evans, a catástrofe em Srebrenica teve três principais razões:

First, there were ambiguities in the language of the protective mandate. Second, there was the required "dual key" agreement between the force commander and the secretary-general's special representative before there could be any coercive response. And then there was the still-prevailing culture of impartiality in peacekeeping operations (a recipe for disaster when there is no peace to keep and spoilers are abroad, as the Brahimi Report later agreed [ONU, 2000, §48-64]) (EVANS, 2008, pp.28- 29, grifos nossos).

\footnotetext{
${ }^{18}$ Neste caso, consentimento aparece explicitamente relacionado aos Estados.
} 


\section{Kosovo}

Em 1998, o presidente sérvio Slobodan Milosevic realizou uma ação militar em Kosovo, perseguindo a população de origem albanesa que lutava pela independência. O Conselho de Segurança não chegou a um consenso, devido principalmente à ameaça de veto da Rússia, uma vez que a Sérvia era uma antiga aliada. Os apelos norte-americanos e da União Europeia não foram suficientes para deter a ofensiva sérvia contra civis. A OTAN, então, resolveu intervir militarmente na região sem a autorização do Conselho de Segurança. A operação recebeu muitas críticas pela escolha do uso de ataques aéreos em detrimento de tropas terrestres durante setenta e oito dias, o que produziu uma série de refugiados e desabrigados, além de mortes de civis (EVANS, 2008, pp. 29-30).

Gareth Evans acredita que a maior polêmica foi o fato de não ter sido uma ação legal, por não ter sido aprovada pelo Conselho de Segurança. Não houve um consenso sobre a natureza humanitária da ação, uma vez que se produziram mortes de civis devido à escolha de ataques aéreos para proteger os kosovares albaneses. A ação da OTAN no Kosovo trouxe o tema da resolução 377, de 1950 (ONU, 1950), novamente à tona: quando o Conselho de Segurança não conseguir tomar as decisões necessárias por conta de impasses políticos, a responsabilidade das decisões para manter e restaurar a segurança e a paz internacionais passa para a Assembleia Geral.

A tabela abaixo, ${ }^{19}$ inspirada no modelo proposto por Mary Kaldor, tem a função de organizar as intervenções dos anos 90 de forma a facilitar a compreensão da dinâmica que envolve uma operação deste tipo:

Tabela 1

\begin{tabular}{|c|c|c|c|}
\hline $\begin{array}{c}\text { Principais } \\
\text { intervenções na } \\
\text { década de 1990 }\end{array}$ & Objetivo & Datas & Tropas envolvidas \\
\hline $\begin{array}{c}\text { Norte do Iraque }- \\
\text { Operação Provide } \\
\text { Comfort }\end{array}$ & $\begin{array}{c}\text { Fornecer zonas de } \\
\text { segurança para os } \\
\text { curdos no Norte do }\end{array}$ & Abril 1991-3 & $\begin{array}{c}20.000 \text { tropas dos } \\
\text { Estados Unidos, } \\
\end{array}$ \\
& $\begin{array}{c}\text { Iraque. Estabelecer } \\
\text { zonas de exclusão } \\
\text { aérea no Sul do Iraque; }\end{array}$ & & \\
& & \\
\hline
\end{tabular}

${ }^{19}$ Cf. tabela original: KALDOR, 2007, pp. 18-21. 


\begin{tabular}{|c|c|c|c|}
\hline Libéria & Parar a guerra civil; & 1990 & $\begin{array}{c}\text { ECOMOG } \\
\text { (ECOWAS Cease- } \\
\text { fire Monitoring } \\
\text { Group) - tropas } \\
\text { lideradas pela } \\
\text { Nigéria; }\end{array}$ \\
\hline Bósnia-Herzegovina & $\begin{array}{l}\text { Zonas de segurança, } \\
\text { corredores } \\
\text { humanitários, zona de } \\
\text { exclusão aérea, } \\
\text { estabelecimento de } \\
\text { tribunais de crimes de } \\
\text { guerra; }\end{array}$ & $1992-5$ & $\begin{array}{l}\text { UNPROFOR, } \\
\text { envolvendo } 23.000 \\
\text { tropas; }\end{array}$ \\
\hline Somália & $\begin{array}{l}\text { Proteção para } \\
\text { distribuição de comida } \\
\text { e fornecimento de } \\
\text { segurança para } \\
\text { assistência } \\
\text { humanitária; }\end{array}$ & $1992-3$ & $\begin{array}{l}\text { UNITAF ( } 37.000 \\
\text { tropas lideradas } \\
\text { pelos Estados } \\
\text { Unidos) e } \\
\text { UNOSOM II } \\
\text { (28.000 tropas); }\end{array}$ \\
\hline Ruanda & $\begin{array}{l}\text { Uma força pequena } \\
\text { das Nações Unidas } \\
\text { retirou-se antes do } \\
\text { massacre. Uma força } \\
\text { liderada pela França } \\
\text { para proteger os } \\
\text { refugiados se instalou } \\
\text { depois do massacre; }\end{array}$ & 1994 & $\begin{array}{l}\text { UNAMIR I (1.500 } \\
\text { tropas) e II (5.500 } \\
\text { tropas). Principais } \\
\text { contingentes: } \\
\text { França, Canadá e } \\
\text { Bélgica; }\end{array}$ \\
\hline $\begin{array}{c}\text { Operação para } \\
\text { Restaurar a } \\
\text { Democracia no Haiti }\end{array}$ & $\begin{array}{l}\text { Liderança americana } \\
\text { para restaurar o } \\
\text { governo eleito } \\
\text { democraticamente; }\end{array}$ & Setembro de 1994 & $\begin{array}{c}\text { Força Multinacional } \\
\text { (MNF), incluindo } \\
21.000 \text { tropas e } \\
1.250 \text { tropas do } \\
\text { Caribe; }\end{array}$ \\
\hline Kosovo & $\begin{array}{l}\text { Ataques aéreos da } \\
\text { OTAN contra a } \\
\text { Iugoslávia; }\end{array}$ & Março-julho de 1999 & $\begin{array}{c}\text { Aeronaves da } \\
\text { OTAN de } 13 \text { países; }\end{array}$ \\
\hline Timor-Leste & $\begin{array}{l}\text { Força liderada pela } \\
\text { Austrália para conter a } \\
\text { violência massiva após } \\
\text { o referendo sobre a } \\
\text { independência; }\end{array}$ & Setembro de 1999 & $\begin{array}{c}\text { INTERFET (Força } \\
\text { Internacional para o } \\
\text { Timor-Leste) - por } \\
\text { volta de } 10.000 \\
\text { tropas lideradas pela } \\
\text { Austrália. } \\
\end{array}$ \\
\hline Serra Leoa & $\begin{array}{l}\text { Série de intervenções } \\
\text { para restaurar o } \\
\text { governo democrático. }\end{array}$ & $1994-2000$ & $\begin{array}{c}\text { Gurkhas. } \\
\text { Executive } \\
\text { Outcomes, } \\
\text { ECOMOG, } \\
\text { UNAMSIL, } \\
\text { Forças britânicas. }\end{array}$ \\
\hline
\end{tabular}

Massacres como o de Ruanda e o de Srebrenica motivaram líderes políticos, como o ex-ministro das relações exteriores da Austrália (1988-1996) e ex-presidente da ONG International Crisis Group (2000-2009), Gareth Evans, e o 
renomado diplomata argelino, Mohamed Sahnoun, a buscarem uma resposta prática e conceitual que deveria unir a comunidade internacional em prevenir e responder por crimes hediondos e atrocidades em massa (EVANS, 2008, p.2). A ICISS, patrocinada pelo governo do Canadá, foi montada com o intuito de promover o debate sobre o difícil dilema entre a relação do princípio de não intervenção e os direitos humanos. Os membros da Comissão são representantes de diversas esferas de atuação (acadêmica, diplomática, política, militar e de organizações internacionais) do Norte e Sul globais. Sob a liderança de Evans e Sahnoun, dez pessoas participaram da Comissão. São eles: Gisèle Côté-Harper, Lee Hamilton, Michael Ignatieff, Vladimir Lukin, Klaus Naumann, Cyril Ramaphosa, Fidel Ramos, Cornelio Sommaruga, Eduardo Stein e Ramesh Thakur.

O conceito de "responsabilidade de proteger" (R2P ou RtoP) foi introduzido pelo Relatório da ICISS, lançado em setembro de 2001, com o objetivo de responder à pergunta feita por Koffi Annan: "If humanitarian intervention is indeed na unacceptable assault on sovereignty, how should we respond to a Rwanda, to a Srebrenica - to gross and systematic violations for human rights that offend every precept o four common humanity?" (EVANS, 2008, p.31). A ideia central desta nova norma é de que todos os Estados têm o dever de garantir segurança e qualidade de vida de seus cidadãos, e quando não o fazem - por incapacidade ou falta de vontade - a comunidade internacional tem responsabilidade de proteger essa população.

Antes de entrar no próximo tópico, vale a pena lembrar que essa ideia já vinha sendo desenvolvida ao longo dos anos noventa pelos Secretários-Gerais Boutros Boutros-Ghali e Kofi Annan - este último sistematizou o argumento em um artigo para a revista The Economist, em 1999, dizendo que não havia apenas um tipo de soberania, mas duas: a tradicional soberania nacional e a soberania individual - relacionada com os direitos humanos.

State sovereignty, in its most basic sense, is being redefined - not least by the forces of globalization and international cooperation. States are now widely understood to be instruments at the service of their peoples, and not vice versa. At the same time individual sovereignty - by which I mean the fundamental freedom of each individual, enshrined in the Charter of the UN and subsequent international treaties - has been enhanced by a renewed and spreading consciousness of human rights. When we read the Charter today, we 
are more than ever conscious that it aim is to protect individual human beings, not to protect those who abuse them (ANNAN, 1999, pp. 49-50 apud EVANS, 2008, p.37, grifos nossos).

\section{A Responsabilidade de Proteger (R2P)}

Enquanto os conceitos têm capacidades políticas e sociais, sua função e performance semânticas não são unicamente derivadas das circunstâncias sociais e políticas às quais eles se referem. Um conceito não é simplesmente indicativo das relações que ele cobre; é também um fator dentro delas. Cada conceito estabelece um horizonte particular para a experiência potencial e a teoria concebível e, neste sentido, estabelece um limite (KOSELLECK, 1985, p. 84 apud JASMIM; JÚNIOR, 2006, p.26).

O sentido incorporado ao conceito de soberania no Relatório publicado pela ICISS em 2001, intitulado The Responsibility to Protect, é um fator e indicador das mudanças práticas e normativas sobre o tema das intervenções humanitárias nas últimas décadas. A noção de responsabilidade de proteger busca equilibrar dois elementos inerentes ao conceito de soberania: i) o contrato vertical entre o soberano e o cidadão - que é a fonte das concepções de direitos humanos; e ii) a autonomia e igualdade horizontal dos Estados - o que resulta na norma de não intervenção e inviolabilidade das fronteiras (HOFFMANN, 1996 apud KENKEL, 2012, p.1).

Para tanto, a nova doutrina propõe duas alterações na retórica das intervenções humanitárias. A primeira está relacionada ao conceito de soberania como um direito absoluto para soberania como responsabilidade. A soberania estatal passa a estar ligada à responsabilidade dos Estados em garantir proteção e bem-estar aos cidadãos e quando estes não cumprem com seus deveres - por incapacidade ou falta de vontade - o princípio da não intervenção deve ceder à responsabilidade internacional de proteger. A intervenção se dá por duas justificativas articuladas com o conceito de segurança humana: a primeira referese à responsabilidade internacional para a promoção e defesa dos direitos individuais; e a segunda, está relacionada com a articulação entre conflitos intraestatais e segurança internacional em um contexto de interdependência entre os Estados.

A modificação, portanto, está no fato de que soberania não é mais um direito automático, inquestionável. Ao contrário, os Estados têm que satisfazer 
certos requisitos normativos a fim de garantir a inviolabilidade da soberania. De acordo com o Relatório da ICISS:

State sovereignty implies responsibility, and the primary responsibility for the protection of its people lies with the state itself. Where a population is suffering serious harm, as a result of internal war, insurgency, repression or state failure, and the state in question is unwilling or unable to halt or avert it, the principle of non-intervention yields to the international responsibility to protect (ICISS, 2001, p. XI).

Vale lembrar que a abordagem de soberania como responsabilidade não é totalmente nova, apesar de o Relatório da ICISS desenvolvê-la de uma forma inovadora, em relação às formas possíveis em que a comunidade internacional pode responder a situações de incumprimento das responsabilidades dos Estados. O trabalho Sovereignty as Responsibility: conflict management in Africa, de Francis Deng (1996) e seus colaboradores, deu uma importante contribuição nesse sentido. O livro afirmava que a soberania deveria ser entendida não apenas como o direito dos Estados "de ficar imperturbados por fora, mas a responsabilidade de exercer as tarefas que se esperam de um governo eficaz" (DENG, 1996, p.73 apud KENKEL, 2012, p.14).

A segunda alteração refere-se à mudança de um "direito de ingerência" para uma "responsabilidade de proteger". Como já foi explicitado, o foco da ação estaria nos interesses dos beneficiários e não no dos Estados responsáveis pela condução das ações. Dessa forma, há uma ampliação do escopo das ações envolvidas nas operações com fins humanitários, destacando-se ações preventivas e não somente reativas. A ICISS estabelece três tipos diferentes de responsabilidades: (1) a responsabilidade de prevenir; (2) a responsabilidade de reagir e (3) a responsabilidade de reconstruir.

A responsabilidade de prevenir é vista como "the single most important dimension of the responsibility to protect" (ICISS, 2001, p. XI) porque um dos princípios de R2P é a afirmação da necessidade de exaurir as opções de prevenção antes de se adotar o uso da força. Para que isso ocorra de forma bem-sucedida, faz-se necessário, primeiramente, identificar aquelas situações que possuem o potencial de gerar crimes de atrocidade em massa; ou as causas de possíveis conflitos em geral. Tais mecanismos de avisos prévios (early warnings) e análise são fundamentais para que as medidas de prevenção diretas e estruturais, 
envolvendo ações de incentivo, possam ser efetivas. Nesse sentido, "the primary focus is on what states at risk can do for themselves, by their own national effort and with their own national capacity, and what they can do voluntarily for each other by way of offering support" (EVANS, 2008, p.86). A ideia principal é que a prevenção de conflitos deva começar e, se for possível, terminar, com o mínimo de intrusão (EVANS, 2008, p.86). Mais uma importante diferença em relação à noção de direito de ingerência.

A responsabilidade de reagir só entra em exercício quando todas as medidas preventivas já falharam, o conflito se estabeleceu, violações dos direitos humanos estão em curso ou são iminentes, e o governo não faz nada para mudar a situação, ou por falta de vontade (porque às vezes ele mesmo é o agressor), ou por incapacidade. Nesse caso, "it is not an option for the world to stand by and do nothing: that way lies, yet again, the horror of Rwanda e Srebrenica. But who should do what, when, and how?" (EVANS, 2008, p.105). Segundo Evans (2008), é importante salientar que a responsabilidade de reagir é sempre do Estado em

questão. Apenas se ele for incapaz ou não quiser, por ser o próprio governo o causador da crise, a responsabilidade recai na comunidade internacional. A responsabilidade de reagir pode envolver desde o estabelecimento de sanções (sem precisar recorrer ao uso da força armada) até intervenções militares em casos mais graves.

O Relatório ICISS sugere quatro princípios para que a ação militar seja justificável. O primeiro é a causa justa, que segue dois critérios principais:

1-Large scale loss of life, actual or apprehended, with genocidal intent or not, which is the product either of deliberate state action, or state neglect or inability to act, or a failed state situation; or 2- Large scale 'ethnic cleansing', actual or apprehended, whether carried out by killing, forced expulsion, acts of terror or rape (ICISS, 2001, p. XII).

O segundo princípio está relacionado com a teoria da Guerra Justa, que tem suas origens no pensamento de Cícero, Santo Agostinho, São Tomás de Aquino e Hugo Grotius. Ele estabelece quatro condições substanciais que devem ser cumpridas desde o início:

Right Intention: the primary purpose of the intervention, whatever other motives intervening states may have, must be to halt or avert human 
suffering. Right intention is better assured with multilateral operations, clearly supported by regional opinion and the victims concerned;

Last Resort: Military intervention can only be justified when every nonmilitary option for the prevention or peaceful resolution of crisis has been explored, with reasonable grounds for believing lesser measures would not have succeeded.

Proportional Means: The scale, duration and intensity of the planned military intervention should be the minimum necessary to secure the defined human protection objective.

Reasonable Prospects: there must be a reasonable chance of success in halting or averting the suffering which has justified the intervention, with the consequences of action not likely to be worse than the consequences of action (ICISS, 2001, p. XII, grifos nossos).

O terceiro princípio trata da questão da autoridade adequada para intervir. O Relatório converge com as estruturas definidas pela Carta da ONU e recomenda que os cinco membros permanentes do Conselho de Segurança concordem em não aplicar o poder de veto que os cabe para obstruir a passagem de resoluções que autorizem a intervenção militar com propósitos humanitários, a não ser que haja algum interesse vital em jogo (ICISS, 2001, p. XIII). Da mesma forma como foi definida na resolução 377 (ONU, 1950), Uniting for Peace, de 1950, no artigo 52, o Relatório ICISS também declara que em casos de inação ou ausência de consenso do Conselho de Segurança, a Assembleia Geral ou organizações regionais devem tomar a liderança para ação.

Por último, o Relatório define os princípios operacionais que devem guiar as intervenções militares com propósitos humanitários - que são marcadamente diferentes das guerras e operações de paz tradicionais. Tais princípios incluem:

(A) Clear objectives; (...) (B) Unity of command; (...) (C) Acceptance of limitations, incrementalism and gradualism in the application of force, the objective being protection of a population, not defeat of a state; (D) Rules of engagement which (...) reflect the principle of proportionality; and involve total adherence to international humanitarian law; (E) Acceptance that force protection cannot become the principal objective; (F) Maximum possible coordination with humanitarian organizations. (ICISS, 2001, p.XIII, grifos nossos). 
$\mathrm{O}$ último componente da $\mathrm{R} 2 \mathrm{P}$ é a responsabilidade de reconstruir, o que implica em ações pós-intervenção humanitária. Segundo o Relatório, "the responsibility to rebuild [is] to provide, particularly after a military intervention, full assistance with recovery, reconstruction and reconciliation, addressing the causes of the harm the intervention was designed to halt or avert" (ICISS, 2001, p. $\mathrm{XI})$. Por isso, tais ações incluem iniciativas de peacebuilding, como a promoção de boa governança, assistência ao desenvolvimento sustentável, compromisso com a segurança básica da população e esforços de justiça e reconciliação. $\mathrm{O}$ Relatório também é explícito em afirmar que, apesar de inicialmente tais tarefas serem organizadas e acionadas pela comunidade internacional, todo o trabalho deve ser voltado para que haja transferência da soberania para administração local o mais rápido possível, mesmo sob a supervisão da ONU, como nos casos de Kosovo e Timor-Leste.

Em resumo, é possível identificar no Relatório da ICISS:

\begin{abstract}
uma tentativa de sistematização das transformações normativas propostas desde "Uma Agenda para a paz", particularmente no que concerne à interpretação proposta ao princípio da soberania nos termos da doutrina liberal democrática ou de sua manifestação nas relações internacionais, o conceito de segurança humana (ESTEVES, 2012, grifo nosso).
\end{abstract}

Em especial, o Relatório consolida a relação entre desenvolvimento e a segurança, colocando ênfase na necessidade de prevenção e da busca pela paz durável através do desenvolvimento sustentável, que inclui:

peacekeeping in support of nation building; disarmament, demobilization, and reintegration (DDR); security sector reform; rebuilding institutions of governance; maximizing local ownership; rebuilding the justice system; managing transitional justice: accountability versus reconciliation; traditional justice; managing refugee returns; economic development and social programs for sustainable peace (EVANS, 2008, pp. 151-172).

A noção de Responsabilidade de Proteger foi mencionada em outros documentos da ONU, como no Relatório do Painel de Alto Nível (High-Level Panel), de 2004; no Relatório In Larger Freedom, de 2005, do Secretário-Geral Kofi Annan; e, por fim, no mais importante documento: o Documento da Cúpula Mundial (ou World Summit Outcome Document), de 24 de outubro de 2005, 
aprovado pela Assembleia Geral. Kai Kenkel (2012) explica com base em dois argumentos a importância deste último documento: o primeiro está relacionado com a autoria - que sinaliza a adesão à R2P pelos chefes de Estado; e o segundo se refere à função do documento em transformar o conceito em uma ação operacionalizável para a comunidade internacional.

$\mathrm{O}$ primeiro parágrafo (138), incluído no item sobre a R2P, destaca a primazia dos Estados da responsabilidade de proteger sua população de genocídio, crimes de guerra, limpeza étnica e crimes contra a humanidade, acrescentando que isso também engloba a prevenção de tais crimes, inclusive a sua incitação, através dos meios necessários e apropriados. O parágrafo 139 também ilumina que a comunidade internacional, através da ONU, deve priorizar o uso de meios pacíficos para proteger as populações desses crimes, e que uma ação coletiva sob o Capítulo VII só deve ocorrer se todas as formas pacíficas forem esgotadas, conforme está abaixo:

Each individual State has the responsibility to protect its populations from genocide, war crimes, ethnic cleansing and crimes against humanity. This responsibility entails the prevention of such crimes, including their incitement, through appropriate and necessary means. We accept that responsibility and will act in accordance with it. The international community should, as appropriate, encourage and help States to exercise this responsibility and support the United Nations in establishing an early warning capability.

The international community, through the United Nations, also has the responsibility to use appropriate diplomatic, humanitarian and other peaceful means, in accordance with Chapters VI and VIII of the Charter, to help to protect populations from genocide, war crimes, ethnic cleansing and crimes against humanity. In this context, we are prepared to take collective action, in a timely and decisive manner, through the Security Council, in accordance with the Charter, including Chapter VII, on a case-by-case basis and in cooperation with relevant regional organizations as appropriate, should peaceful means be inadequate and national authorities are manifestly failing to protect their populations from genocide, war crimes, ethnic cleansing and crimes against humanity. We stress the need for the General Assembly to continue consideration of the responsibility to protect populations from genocide, war crimes, ethnic cleansing and crimes against humanity and its implications, bearing in mind the principles of the Charter and international law. We also intend to commit ourselves, as necessary and appropriate, to helping States build capacity to protect their populations from genocide, war crimes, ethnic cleansing and crimes against humanity and to assisting those which are under stress before crises and conflicts break out (ONU, 2005). 
Segundo Kai Kenkel, durante as negociações do Documento da Cúpula Mundial, vários países contestaram sobre pontos cruciais do conceito, inclusive a Índia e o Brasil, que viam a possibilidade dessa nova norma ser utilizada para violar o princípio tradicional de soberania, justificando, assim, ações unilaterais, e, principalmente, por parte das potências do Norte, como foi comum no passado.

Ban-Ki-Moon tentou clarificar, em uma palestra dada em 15 de julho de 2008, que a R2P não tinha a intenção de enfraquecer o princípio tradicional da soberania e muito menos permitir ações unilaterais dos países do Norte. Ao contrário, ele afirmou que esta norma busca fortalecer o componente vertical da soberania - que corresponde à responsabilidade dos Estados em proteger e defender seus cidadãos dos crimes citados no Documento da Cúpula Mundial. Além disso, ele lembrou terem sido dois Secretários-Gerais africanos, Boutros Boutros-Ghali e Kofi Annan, que primeiramente discutiram as noções de soberania e intervenção humanitária, destacando que a União Africana já havia endossado a ideia antes mesmo de 2005. Ademais, a intervenção só aconteceria em último caso, só depois de todas as soluções pacíficas terem falhado, o que comprovaria que a R2P não pretendia se distanciar da primazia da soberania dos Estados (ONU, 2008):

Finally, let me clear up two more misconceptions and then say a word about how we are proceeding in the effort to turn promise into practice, words into deeds. Some contend that RtoP is a Western or Northern invention, being imposed on the global South. Nothing could be further from the truth. It was the first two African Secretaries-General of the United Nations -- Boutros Boutros-Ghali and Kofi Annan -- who first explored evolving notions of sovereignty and humanitarian intervention. And the African Union has been explicit: in the year 2000, five years before the Summit declaration, the African Union asserted "the right of the Union to intervene in a member State pursuant to a decision of the Assembly in respect of grave circumstances, namely: war crimes, genocide and crimes against humanity".

Equally incorrect is the assumption that the responsibility to protect is in contradiction to sovereignty. Properly understood, RtoP is an ally of sovereignty, not an adversary. Strong States protect their people, while weak ones are either unwilling or unable to do so. Protection was one of the core purposes of the formation of States and the Westphalian system. By helping States meet one of their core responsibilities, RtoP seeks to strengthen sovereignty, not weaken it. (ONU, 2008, grifos nossos). 
$\mathrm{Na}$ mesma palestra, o Secretário-Geral explicou que a ONU propõe o engajamento com a R2P de uma forma "estreita, mas profunda" ("narrow, but deep"). Estreita porque esta norma está relacionada somente aos quatro crimes mencionados no Documento da Cúpula Mundial: genocídio, crimes de guerra, limpeza étnica e crimes contra a humanidade. Profunda por se tratar de uma norma que engloba não apenas o elemento da força militar, mas também as ferramentas da ONU direcionadas para a prevenção e proteção.

Its scope is narrow, focused solely on the four crimes and violations agreed by the world leaders in 2005. Extending the principle to cover other calamities, such as HIV/AIDS, climate change or response to natural disasters, would undermine the 2005 consensus and stretch the concept beyond recognition or operational utility.

At the same time, our response should be deep, utilizing the whole prevention and protection tool kit available to the United Nations system, to its regional, subregional and civil society partners and, not least, to the Member States themselves. As the Summit urged, we need to enhance UN early warning mechanisms, integrating the system's multiple channels of information and assessment. We need to strengthen the capacities of States to resist taking the path to genocide, war crimes, ethnic cleansing and crimes against humanity (ONU, 2008, grifos nossos).

Uma abordagem "estreita, mas profunda" seria baseada em três pilares centrais, segundo o Secretário: o primeiro pilar se refere ao fortalecimento da capacidade estatal, ou seja, na primazia da soberania dos Estados; o segundo pilar está relacionado à prevenção - ao compromisso da comunidade internacional em assistir aos Estados a alcançarem tais obrigações (atividades de desenvolvimento, capacity-building); e o terceiro pilar refere-se à responsabilidade da comunidade internacional em responder, de forma efetiva, aos quatro crimes delimitados no Documento da Cúpula de 2005, por meios pacíficos em primeiro lugar, e, em último caso, com o uso da força.

First, Governments unanimously affirmed the primary and continuing legal obligations of States to protect their populations -- whether citizens or not -from genocide, war crimes, ethnic cleansing and crimes against humanity, and from their incitement. (...)

The second, more innovative pillar speaks to the United Nations institutional strengths and comparative advantages. The Summit underscored the commitment of the international community to assist States in meeting these obligations.

Our goal is to help States succeed, not just to react once they have failed to meet 
their prevention and protection obligations. It would be neither sound morality, nor wise policy, to limit the world's options to watching the slaughter of innocents or to send in the marines. (...)

The third pillar is much discussed, but generally understood too narrowly. It is Member States' acceptance of their responsibility to respond in a timely and decisive manner, in accordance with the United Nations Charter, to help protect populations from the four listed crimes and violations. The response could involve any of the whole range of UN tools, whether pacific measures under Chapter VI of the Charter, coercive ones under Chapter VII, and/or collaboration with regional and subregional arrangements under Chapter VIII. The key lies in an early and flexible response, tailored to the specific needs of each situation (ONU, 2005, grifos nossos).

Nesse contexto, Ban-Ki-Moon alerta para uma diferença fundamental entre a R2P e o conceito de segurança humana. Como foi visto anteriormente, este último envolve a segurança das pessoas - e não apenas de Estados - em relação a uma série de ameaças que não apenas os quatro crimes estabelecidos no escopo da R2P: "RtoP should be also distinguished from its conceptual cousin, human security. The latter, which is broader, posits that policy should take into account the security of people, not just of States, across the whole range of possible threats" (ONU, 2008, grifos nossos).

A análise do desenvolvimento das normas de segurança coletiva desde a Guerra Fria até a emergência do conceito de Responsabilidade de Proteger aponta para uma crescente articulação entre a noção de emergência humanitária e a prática da intervenção, e, simultaneamente, entre a ideia de prevenção de conflitos e o desenvolvimento. O próximo capítulo pretende discutir a posição brasileira em face dessas mudanças, principalmente durante o período do governo do presidente Fernando Henrique Cardoso (1995-2002). 


\section{Capítulo 2 - O Brasil e a nova agenda de segurança da ONU}

Este capítulo tem como objetivo analisar o posicionamento do Brasil em face das transformações da agenda de segurança internacional no pós-Guerra Fria, especialmente em relação ao tema da intervenção humanitária e peacebuilding (consolidação da paz). Para tanto, o enfoque será dado ao período do governo do presidente Fernando Henrique Cardoso (1995-2002). Além disso, a análise será conduzida a partir de alguns eixos de estruturação da política externa brasileira (PINHEIRO, 2000), segundo a perspectiva de analistas e diplomatas, quais sejam: a) a busca por autonomia; b) a primazia do desenvolvimento; c) o compromisso do país com o multilateralismo. Dentro desse contexto, pretende-se avaliar brevemente a reação do Brasil na primeira intervenção no Haiti, em 1994, com o propósito de auxiliar na comparação com a recente intervenção, em 2004, que será discutida no terceiro capítulo.

O tema da autonomia está bastante presente tanto na literatura sobre política externa brasileira quanto nos discursos dos próprios agentes diplomáticos. $\mathrm{Na}$ verdade, no Brasil essas duas funções se confundem, uma vez que "diplomatas se apresentam e/ou são vistos, ao mesmo tempo, como operadores e analistas da política externa brasileira e/ou das relações internacionais de uma forma mais ampla” (PINHEIRO, 2004, p.3; Cf. PINHEIRO; VEDOVELI, 2010). É interessante notar que o termo já recebeu uma série de qualificações: autonomia na dependência (MOURA, 1980), autonomia pela distância (FONSECA JR., 1998), autonomia pela participação (FONSECA JR., 1998), autonomia pela integração (VIGEVANI; OLIVEIRA; CINTRA, 2003) e a mais recente autonomia pela diversificação (VIGEVANI; CEPALUNI, 2007). Entretanto, as estratégias adotadas para se alcançar a referida autonomia e o próprio conteúdo do termo tem variado ao longo da história da política externa brasileira. Ou seja, certamente o que significa autonomia para o Itamaraty hoje não é a mesma coisa que significava para o Rio Branco.

De qualquer forma, analistas e diplomatas costumam entender que autonomia significa "either independence or multiple dependence, and it has to be pursued first and foremost, to avoid been in a subjugated position (especially 
regarding the main powers) and second, to allows Brazil to pursue its national interest" (ESTEVES, 2012a).

Outra definição útil para o sentido político do termo é dada por Russel e Tokatlian:

[Autonomia] é uma condição do Estado-nação que lhe possibilita articular e alcançar objetivos políticos de forma independente. De acordo com este significado, autonomia é uma propriedade que o Estado-nação pode ter ou não, ao longo de um contínuo em cujos extremos se apresentam duas situações: total dependência ou completa autonomia (PINHEIRO, 2000, p. 313).

Podendo ser aplicado para situações domésticas e internacionais, a noção de "autonomia" é geralmente utilizada para:

caracterizar a habilidade do Estado, entendida como capacidade e disposição para tomar decisões baseadas em necessidades e objetivos próprios sem interferências nem constrangimentos externos e para controlar processos ou acontecimentos que se produzem além de suas fronteiras. Em ambos os casos, a autonomia é sempre uma questão de grau que depende, fundamentalmente, das capacidades, duras e brandas, dos Estados e das circunstâncias externas que lhes apresentam (PINHEIRO, 2000, p. 313).

A política externa brasileira na maior parte do século $\mathrm{XX}$, da gestão do Barão do Rio Branco (1902-1912) até o início do governo do presidente Fernando Collor de Mello (1990), tem sido analisada a partir de dois paradigmas diplomáticos: o americanismo e o globalismo (PINHEIRO, 2000, p.308), apesar de ambos terem sofrido modificações no conteúdo e na aplicação ao longo do tempo, de acordo com os contextos históricos. Basicamente, o americanismo pode ser entendido "como o paradigma que concebia os Estados Unidos como eixo da política externa, donde uma maior aproximação a Washington elevaria os recursos de poder do país, aumentando assim sua capacidade de negociação" (LIMA, 1994, pp. 35-36 apud PINHEIRO, 2000, p.308). Enquanto que o globalismo pode ser definido "como uma alternativa ao anterior, contrapunha a esta tese aquela que elegia a diversificação das relações exteriores do Brasil como condição do seu poder de barganha no mundo, inclusive junto aos Estados Unidos" (LIMA, 1994, pp. 35-36 apud PINHEIRO, 2000, p.308).

Há uma percepção tanto de analistas como de diplomatas que o objetivo de garantir espaços de autonomia sempre fez parte da política externa brasileira, 
estando presente mesmo no período de grande dependência em relação aos Estados Unidos (MOURA, 1980; HIRST, 1996 apud PINHEIRO, 2000, p.313), o que foi denominado como autonomia na dependência. Foi assim durante a Guerra Fria, quando o Brasil buscou autonomia a partir de uma postura mais distante dos debates internacionais (PINHEIRO, 2000, p.313), o que foi caracterizado como a busca por autonomia pela distância.

Um dos fatores determinantes da política externa brasileira é sua localização no hemisfério ocidental, especialmente na América do Sul (LIMA; HIRST, 2009, p.45). Historicamente, a influência do poder americano na região tem sido constante e em alto grau. As intervenções norte-americanas na América Latina baseadas seja no Corolário Roosevelt (em adição à Doutrina Monroe) ou no embate da Guerra Fria, foram decisivas para a grande desconfiança dos países latino-americanos quanto às intenções dos Estados Unidos no continente (PATRIOTA, 1998, p.131). Expressando preocupação sobre a grande influência dos EUA no Conselho de Segurança e diante da ampliação da agenda de segurança da ONU, em meados dos anos noventa, o Ministro Luiz Felipe Lampreia, em Conferência sobre o Brasil no Século XXI, declarou:

no horizonte previsível as relações internacionais serão dominadas, do ponto de vista estratégico-militar, pelo unipolarismo, como predomínio da única superpotência remanescente do período anterior, os Estados Unidos, cuja perda apenas relativa - de poder econômico em nada alterou sua condição de único ator global capaz de jogar e influir nos diversos tabuleiros diplomáticos (LAMPREIA, 1996, p.45 apud PATRIOTA, 1998, p.197).

As instituições regionais, então, passam a ter como principal papel criar mecanismos contra as possíveis intervenções de potências estrangeiras, inclusive fornecendo garantias legais baseadas na definição absoluta de soberania (KENKEL, 2012a, p.6). A preocupação está focada, como destaca Ramesh Thakur (2011, p.144 apud KENKEL, 2012a, p.6), "on justice among rather than within nations”. Na Carta da Organização dos Estados Americanos (OEA, 1948), a ideia de não intervenção está prevista nos Artigos 19-22, que estabelecem que o território de um Estado é inviolável e que qualquer medida coercitiva, de qualquer natureza, só é aceitável em casos de autodefesa. Nesse sentido, Cabranes (1967, p.1147 apud KENKEL, 2012a, p.6) esclarece que "for more than a decade after its 
founding, the Organization of American States (OAS) exhibited no particular inclination to undertake a program to provide international protection for fundamental freedoms within member states".

A percepção dos diplomatas brasileiros sobre a ênfase na região do conceito absolutista de soberania e da forte restrição ao uso da força é bastante positiva, uma vez que garantiram "o êxito com que a paz e a democracia têm sido preservadas na América do Sul" (PATRIOTA, 1998, p. 197). De fato, o continente só teve um conflito significativo: a Guerra do Paraguai (1864-1870). Segundo Kai Kenkel (2012a, p.7), apesar dos altos índices de homicídios com armas de fogo na região, nunca houve algo parecido como o Holocausto ou o Genocídio em Ruanda, embora os terríveis episódios de tortura durante os regimes militares tenham resultado em um engajamento maior com a noção de Responsabilidade de Proteger (R2P) pelo Chile e Argentina. Segundo Kai (2012a, pp. 7-8), isso fez com que os governos latino-americanos não sentissem uma urgência em tratar das questões humanitárias nem se impactassem com o "horror da inação" (ICISS, 2001, p.1, § 1.1).

É dentro desse contexto específico que as diretrizes da política externa brasileira são firmadas: "uma interpretação absolutista da soberania estatal como inviolabilidade das fronteiras, forte dedicação ao princípio multilateralista e, por último, uma forte preferência pela negociação e um repúdio ao uso da força no âmbito internacional" (KENKEL, 2012a, p.2, tradução nossa). A Constituição Federal de 1988 estabeleceu, em bases legais, os preceitos da não intervenção nos assuntos internos dos Estados, da solução pacífica de controvérsias e do comprometimento do país com as normas internacionais de direitos humanos, inclusive com a condenação do racismo, como consta no artigo $4^{\circ}$ :

I - independência nacional; II - prevalência dos direitos humanos; III autodeterminação dos povos; IV - não intervenção; V - igualdade entre os Estados; VI - defesa da paz; VII - solução pacífica dos conflitos; VIII - repúdio ao terrorismo e ao racismo; IX - cooperação entre os povos para o progresso da humanidade; $\mathrm{X}$ - concessão de asilo político (grifos nossos).

Kai Kenkel (2008; 2010, p.653) destaca que a Constituição não estabelece uma hierarquia entre os princípios de direitos humanos e de não intervenção, o que dificulta estabelecer, pelo menos inicialmente, uma posição mais direta sobre 
a emergência de normas que envolvam a tensão entre o componente vertical e horizontal da soberania, como a Responsabilidade de Proteger. Isso porque as mudanças na prática internacional - desenvolvidas no primeiro capítulo colocaram esses dois elementos, de certo modo, em contradição mútua (KENKEL, 2008, p. 42). O autor lembra, porém, que tal tensão tem sido resolvida pela ênfase ao princípio da não intervenção, dando a primazia ao componente horizontal da soberania (KENKEL, 2008; 2012).

Após a aprovação da Constituição Federal de 1988, os elementos-chaves que orientam a política exterior brasileira também foram consagrados legalmente no documento que apresentou a Política de Defesa Nacional, em novembro de 1996. Dentre as vinte diretrizes específicas, enumeradas no texto, cinco pelo menos, afetam diretamente a atuação do Brasil no campo da segurança (PATRIOTA, 1998, p.189). São elas:

\begin{abstract}
a) contribuir para a construção de uma ordem internacional baseada no estado de direito, que propicie a paz universal e regional e o desenvolvimento sustentável da humanidade; b) participar crescentemente dos processos internacionais relevantes de tomada de decisão; c) aprimorar e aumentar a capacidade de negociação do Brasil no cenário internacional; d) participar de operações internacionais de manutenção da paz, de acordo com os interesses nacionais; h) intensificar o intercâmbio com as Forças Armadas das nações amigas. Referências à solução pacífica de controvérsias e uso da força apenas como recurso de autodefesa reafirmam a orientação não coercitiva de nossa postura externa (BRASIL, 1996 apud PATRIOTA, 1998, p.190).
\end{abstract}

Assim, o uso da força seria permitido apenas como recurso de autodefesa, conforme consta na Carta da OEA. Além disso, as referidas diretrizes sustentam a busca por autonomia nacional, entendida como a necessidade de maior participação do Brasil nos fóruns internacionais. No campo da segurança, o texto é explícito em restringir a participação brasileira às operações de manutenções da paz (peacekeeping), com a intencional ressalva de esta participação estar de acordo com os interesses nacionais, apesar de não estar claro o que constituem tais interesses.

O "desejo de autonomia", conforme denominou Fonseca Júnior, reaparece com novas características e a partir de novas estratégias no período democrático. Para Letícia Pinheiro, nesta nova fase, a política externa brasileira seria orientada pelo paradigma do institucionalismo pragmático, que, em resumo, "supõe que - 
e trabalha no sentido de - quanto maior a presença brasileira no sistema internacional através das instituições, maior o acesso ao desenvolvimento e à autonomia de ação" (PINHEIRO, 2000, p.326). Dito de outra forma, a ideia é que o Brasil passa a ser um apoiador e participante ativo dos fóruns multilaterais com maior ou menor grau de institucionalização (no sentido de adesão aos princípios e normas) - de acordo com as possíveis vantagens das negociações. A autora supõe por institucionalização "a medida que o comportamento de fato se conforma com os princípios e as normas" (KRASNER, 1999, p.44 apud PINHEIRO, 2000, p.319) e que "quanto maior a conformidade entre o comportamento e as regras institucionais, mais alto o nível de institucionalização" (KRASNER, 1999, p.56 apud PINHEIRO, 2000, p.319). E por vantagem pode-se entender como a garantia da liberdade de ação e do exercício do papel de liderança. Enfim, essa seria uma estratégia que, em última análise, visa "garantir a autonomia por meio do aumento de poder" (PINHEIRO, 2000, p.316).

Segundo a autora, o institucionalismo pragmático recupera as naturezas grotiana e hobbesiana do realismo da política externa brasileira. Assim, "para além da concepção grotiana que na busca por justiça percebe o sistema de Estados regido por regras e princípios", se adicionam "as premissas do realismo hobbesiano que irá acrescentar os interesses e as atitudes em seu benefício como constitutivos da ordem" (PINHEIRO, 2000, p.318, grifos da autora). Por isso, Letícia Pinheiro completa que esta é uma lógica de duble standard:

o grau de comprometimento que o Estado se propõe a assumir varia conforme seus recursos de poder, e, principalmente, no fato de que, embora na prática se adote essa estratégia, no discurso a política externa contemporânea vem sendo apresentada como tributária de uma concepção que se move pelos princípios da cooperação e não pelos interesses (PINHEIRO, 2000, pp.319-320).

A lógica de duble standard pode ser entendida como uma postura típica de uma potência emergente, que busca a manutenção de elementos da ordem global quando esta a privilegia em relação aos seus vizinhos, ao mesmo tempo em que procura a reforma desses elementos quando estes são desvantajosos em relação às grandes potências (KENKEL, 2010, p.654). Kai Kenkel (2010) também ressalta que há uma tendência das potências emergentes em usar a dominância regional como um trampolim para a busca de maior influência no plano global. No entanto, 
isso pode levar a uma situação complexa: por ser líder regional, muitas vezes, o país se sente obrigado a defender princípios e normas regionais que são incompatíveis com aqueles defendidos no nível global pelos países do Norte (KENKEL, 2010, p. 649). Este parece ser o caso do Brasil em relação ao tema das intervenções humanitárias, especialmente a partir do governo Lula, como será desenvolvido no terceiro capítulo.

Segundo Kenkel (2012a, p.19)

typically, emerging powers will both participate in strengthening the mechanisms of multilateral governance when it is advantageous while simultaneously seeking their reform. This creates a strong emphasis on being on the "inside" of the deliberative process. They are, often as regional powerhouses, simultaneously central leaders and peripheral followers in the international system (SCHIRM, 2010), though clearly set on attaining the former function exclusively.

O papel de uma potência emergente pode variar ao longo do tempo e, por isso, "has to be rethought continually in the context of the changing state of the international system" (COX, 1989, p.824 apud KENKEL, 2010, p.647). Os critérios comumente utilizados para identificação de uma potência média durante a Guerra Fria já não são os mesmos utilizados a partir da década de 90. Eduard Jordaan (2003, p.166 apud KENKEL, 2010, p.648) estabelece essa diferença analítica a partir de seis fatores que são constitutivos (relacionadas às análises funcionais e hierárquicas) e comportamentais dos quais são destacados cinco: 1 estabilidade democrática - potências médias tradicionais têm democracias estabelecidas enquanto potências emergentes muitas vezes possuem uma democracia frágil; 2 - foco das políticas externas - o foco das potências médias tradicionais se direcionava para questões militares e estratégicas enquanto potências emergentes tendem a focar nas questões econômicas; 3 - desigualdade social - as potências médias tendem a ter uma distribuição altamente igualitária da riqueza enquanto as potências emergentes costumam apresentar profundas desigualdades sociais; 4 - posições na economia política global - as potências médias estão no núcleo da produção global enquanto as potências emergentes estão localizadas na semiperiferia da produção global; 5 - atitudes em direção à integração regional - o status de potência emergente é quase sempre baseado na preponderância regional, o que tanto fortalece e dificulta os esforços desses Estados em busca da autonomia da política externa: "[t]raditional middle powers 
appear rather ambivalente about regional integration and cooperation, whereas emerging middle powers are keen participants and often initiators 'thereof'" (JORDAAN, 2003, p.173 apud KENKEL, 2010, p.648).

Um segundo eixo de estruturação da política externa brasileira, segundo analistas e diplomatas, é a busca pelo desenvolvimento, que está também associado ao "desejo de autonomia". Todas as tentativas de modernização implementadas no país, segundo Adam Przeworski (1993, p.223 apud PINHEIRO, 2000, p.312) “concebiam o desenvolvimento como um projeto ligado à independência nacional, econômica e política”. Segundo Letícia Pinheiro (2000, p.311), o objetivo do desenvolvimento sempre esteve presente, pelo menos dos anos 30 e 90, mudando somente as visões do melhor meio de alcançá-lo. Para as autoras Maria Regina Soares de Lima e Mônica Hirst (2009. p.46), isso deve ao fato de o Brasil estar localizado em uma região estável e na área de influência direta dos Estados Unidos - o que fez com que as elites brasileiras priorizassem as questões econômicas, e não militares ou de segurança. Assim, a economia é vista como o principal fator de risco e ameaça para o país, o que resultou em uma agenda de política externa condicionada predominantemente "pelo modelo econômico vigente, e [sua] evolução [...] vinculada às conjunturas críticas do desenvolvimento de tal modelo" (LIMA; HIRST, 2009, p.46). Segundo as autoras, as conjunturas críticas são provocadas por uma combinação simultânea de transformações sistêmicas e domésticas: "são momentos nos quais os padrões dominantes de desenvolvimento econômico interno e a inserção internacional se esgotam e uma nova coalizão sociopolítica emerge, alterando tanto a política econômica externa quanto a política externa (LIMA; HIRST, 2009, p.46).”

De acordo com as autoras, duas conjunturas críticas foram geradas ao longo do século XX: a primeira se deu com a crise do modelo agroexportador e a consequente adoção do modelo de industrialização por substituição de importações (ISI), nos anos 30; e a segunda se originou do esgotamento do regime de "industrialização protegida", o que acabou resultando em sua substituição por um modelo de integração competitiva à economia global, nos anos noventa. $\mathrm{O}$ modelo de ISI foi consolidado no plano doméstico e externo com a ajuda da atuação da política externa brasileira - que passou a reivindicar, de forma crescente, sobre a necessidade de um tratamento distinto para os países em desenvolvimento no regime de comércio internacional, o que incluiria a criação de 
um Sistema Geral de Preferências (SGP) para as exportações de países em desenvolvimento, com vista à abertura de novos mercados, e a expansão da cooperação econômica entre países do Sul (LIMA; HIRST, 2009, p.46).

O esgotamento do modelo de ISI, por sua vez, contribuiu para a crise do paradigma diplomático vigente - o globalismo (PINHEIRO, 2000, p.311). A partir dos anos 90 - com a inserção do país no projeto neoliberal - a busca pelo desenvolvimento permanece ainda como uma forma de preservar a lógica da autonomia. Mas para alcançar o desenvolvimento - tanto no período do presidente Collor, como do Itamar Franco, e mais fortemente do Fernando Henrique Cardoso (FHC) - o governo adotou medidas de estabilidade macroeconômica e reformas constitucionais e políticas para atrair investimentos estrangeiros. A política externa se tornou um instrumento importante para esse modelo de desenvolvimento, que buscava recuperar a credibilidade e a confiança do país junto aos potenciais parceiros internacionais (LIMA; HIRST, 2009, p.49). A autonomia viria, portanto, da participação ativa em todos os regimes internacionais e a capacidade do país em cooperar na criação de regras e instituições - mas sempre visando o alcance de uma maior liberdade de ação e/ou poder de barganha no cenário internacional, o que foi chamado de uma estratégia de autonomia pela participação.

Segundo Cardoso (2000, p.6 apud VIGEVANI; OLIVEIRA; CINTRA, 2003, p.36), “o Brasil que entra no século XXI é um país cujos objetivos prioritários de transformação interna, de desenvolvimento, estão em consonância com os valores que se difundem e se universalizam no plano internacional". Assim, a redemocratização e a abertura econômica colocaram o Brasil em convergência ao conjunto de valores e práticas que orientavam a vida internacional. Contudo, como afirmou Luiz Felipe Lampreia ${ }^{20}$ (2001, p.3 apud VIGEVANI; OLIVEIRA; CINTRA, 2003, pp.36-37), sempre de forma crítica, pois "a observância dos valores e dos compromissos que compõem esse mainstream continua a padecer de graves distorções e incoerências, alimentadas e facultadas pela prevalência das assimetrias de poder sobre o princípio da igualdade jurídica”.

\footnotetext{
${ }^{20}$ Ministro das Relações Exteriores no governo do Presidente Fernando Henrique Cardoso entre 1995 e 2001.
} 
Essa estratégia também chamada de convergência crítica, ou ainda autonomia pela integração (VIGEVANI; OLIVEIRA; CINTRA, 2003), orientou a política externa dos oito anos de governo de FHC, e foi marcada pela participação ativa do Brasil na organização e na regulamentação das relações internacionais, nas mais diversas áreas, contribuindo para o estabelecimento de um ambiente favorável ao seu desenvolvimento econômico e social. Para Lima e Hirst (2009), o comprometimento do país com o multilateralismo - como um eixo de estruturação da política externa brasileira - está presente desde o fim do século XIX. As autoras afirmam que o Brasil sempre se envolveu ativamente em instituições e arenas multilaterais a partir desse período, o que explica ter sido o único país sul-americano a participar da I Guerra Mundial como beligerante, conferindo-lhe presença na Conferência de Paz em Paris, em 1919 (LIMA; HIRST, 2009, pp.50-56).

Além disso, elas confirmam que o país buscou a reforma da Liga das Nações e após a criação da ONU, da qual o Brasil é membro-fundador, participou ativamente das principais conferências que levaram à ordem multilateral criada após 1945. O país também é um dos 23 fundadores do Acordo Geral sobre Tarifas e Comércio (Gatt, em inglês) e uma das 56 nações representadas na Organização Internacional do Comércio (OIC), em Havana. Dessa forma, as autoras concluem que o Brasil "tem sido consistentemente ativo em negociações sobre comércio e desenvolvimento desde 1945" (LIMA; HIRST, 2009, p.51).

No campo das questões de segurança e paz internacionais, as autoras ressaltam que, durante a Guerra Fria, o Brasil adotou uma postura mais defensiva e discreta, quando, por exemplo, se recusou a assinar o Tratado de Não Proliferação Nuclear (TNP), em 1960, entendendo o documento "como uma clara expressão da tendência ao "congelamento do poder mundial"” (LIMA; HIRST, 2009, p.54). Para Paulo Esteves (2012a, p.2), o Brasil, que se ausenta deliberadamente 20 anos do Conselho de Segurança como membro não permanente (1968-1988), retorna aos debates sobre segurança, nos anos noventa, com bastante cautela: enquanto o país concordou com algumas das mais importantes normas internacionais em proliferação e desarmamento, acendendo ao Regime de Controle de Tecnologia de Mísseis (MTCR, em inglês), em 1994, e ratificando o TNP, em 1998, por exemplo, também se manifestou de forma cética e receosa em relação ao avanço de uma agenda mais intervencionista. 
Nesse período, o Brasil defendeu fortemente reformas no sistema da ONU e uma maior representatividade no Conselho de Segurança, ao mesmo tempo em que buscou ser mais cauteloso com resoluções e medidas que iam contra os princípios tradicionais da política externa brasileira, especialmente aquelas baseadas no Capítulo VII. Na ocasião em que o Brasil atuou como membro do Conselho, no biênio 1998/1999, o discurso diplomático enfatizou que a participação brasileira era uma oportunidade não só de "contribuir para o cumprimento das obrigações do órgão sob a Carta das Nações Unidas, mas também de trabalhar 'de dentro' na tentativa de ajudar a corrigir os muitos desequilíbrios presentes nos procedimentos do Conselho" (FONSECA JR., 2002, p.16). A postura brasileira foi considerada em alguns momentos como paradoxal: de promoção dos valores democráticos, inclusive, defendo-os quando são ameaçados em algum lugar no mundo, e, ao mesmo tempo, dedicação ao princípio da soberania nacional e da não interferência nos assuntos domésticos (SANTISO, 2000). Aliás, segundo Carlos Santiso (2000), o ativismo do Presidente Cardoso foi bastante importante para o fortalecimento dos fundamentos democráticos do sistema interamericano, advogando pela introdução de cláusulas democráticas em acordos regionais e internacionais.

Assim, no âmbito regional, o Brasil percebia a possibilidade e a necessidade de exercer um papel influente e de atuar proativamente (MARQUES, 2005). O Brasil buscou ter uma postura de liderança no trabalho de cooperação e fortalecimento das instituições multilaterais (como a OEA) para solucionar conflitos que pudessem abalar a democracia da região. Os casos da crise do Paraguai, em 1996, do Equador e do Peru em 2000, e da Venezuela, em 2002, foram tratados pelo Brasil como oportunidades para o país exercer sua potencialidade diplomática.

$\mathrm{Na}$ perspectiva global, o país buscou "a reforma e o fortalecimento do Conselho de Segurança da ONU com dois propósitos centrais: prevenir e deslegitimar a aplicação unilateral do uso da força e outras condutas discricionárias no campo da segurança internacional; e obter representação internacional mais equilibrada no referido campo" (VAZ, 2006, p.67). Segundo Lima e Hirst, o Brasil tem se concentrado em três aspectos na reivindicação antiga de reforma da ONU: 
1 - o fortalecimento de princípios e normas multilaterais, particularmente no que diz respeito à autorização para o uso de instrumentos coercitivos, como previsto pelo Capítulo VII da Carta da ONU; 2 - a necessidade de restabelecer a fronteira conceitual entre peacekeeping e peace-enforcement; e 3 - a reformulação da estrutura decisória do Conselho de Segurança visando aumentar sua representatividade e legitimidade na ordem pós-Guerra Fria. A auto-percepção do país como mediador entre fracos e fortes e o uso da diplomacia "parlamentar" são vistos como meios viáveis de conquistar maior influência (LIMA; HIRST, 2009, p.55, grifos nossos).

Após a Guerra do Golfo, o Brasil passou a "avaliar os interesses e posições norte-americanas sob a perspectiva das preocupações com o intervencionismo, preocupações que haviam se fortalecido, particularmente no seio das Forças Armadas brasileiras [...]” (VAZ, 2006, p.65). A posição do Brasil insistia na reciprocidade de conduta das relações entre o mundo desenvolvido e o em desenvolvimento. E a possibilidade de intervenção que se abria em uma nova perspectiva da agenda de segurança internacional era vista com algumas ressalvas.

\section{O Brasil e as Operações de Paz}

Dessa forma, até 2004, a posição brasileira essencialmente orientada pelo princípio da não intervenção levou à rejeição do país em fazer parte de qualquer missão com o mandato sob o Capítulo VII (ou seja, qualquer proposta de peaceenforcement ou intervenção humanitária), limitando seu suporte ao Capítulo VI, tipicamente em "missões da primeira geração". ${ }^{21}$ De acordo com a declaração do Ministro Lampreia (1999, p.327 apud ESTEVES, 2012b, p.4, tradução nossa), "como um país intermediário, com uma tradição pacífica e longa, não podemos, contudo, apoiar o uso unilateral de meios militares, mesmo contra grandes violadores da ordem internacional como o Iraque".

A primeira participação brasileira em uma operação de paz se deu na Comissão Leticia da Liga das Nações em razão do conflito fronteiriço na região amazônica entre Peru e Colômbia. Desde a criação da ONU, a contribuição

\footnotetext{
${ }^{21}$ Segundo Kai Kenkel (2012b), as operações de primeira geração seriam aquelas tradicionais, de interposição após um cessar-fogo; e as de segurança geração começam a partir do fim da Guerra Fria - quando passam a assumir tarefas civis como a organização de eleições, desarmamento, direitos humanos e ajuda humanitária.
} 
brasileira às operações de paz tem sido contínua, apesar de limitada. A maior parte da participação do país consistiu no envio de militares observadores e funcionários, com exceção dos contingentes enviados para o Suez (UNEF I, 19561967) e Angola (UNAVEM III, 1995-1997), assim como um grande contingente policial para UNTAET (1999-2002) (KENKEL, 2012a, p.11). O Brasil também forneceu comandantes militares para UNEF (United Nations Emergency Force) I (1964), UNOMOZ (United Nations Operation in Mozambique) (1993-94) e Corpos de Observadores Militares para UNAVEM (United Nations Angola Varification Mission) I (1988-91) (KENKEL, 2010, pp.655-656).

O fato das tropas brasileiras terem sido estabelecidas em áreas de prioridade da política externa do país (países africanos lusófonos ou antigas colônias portuguesas e constante fluxo de observadores militares ganhando influência no Oriente Médio) pode ser percebido como um comportamento típico de uma potência média (KENKEL, 2010, p. 656).

\section{O Brasil e a agenda de segurança da ONU nos anos 90}

O documento "Uma Agenda para a Paz" (ONU, 1992) foi percebido pelo governo brasileiro como uma "reinterpretação do mandato do Conselho de Segurança em um sentido militarizante" (PATRIOTA, 1998, p. 57). Segundo os diplomatas, isso significava substituir a ênfase nos instrumentos de diplomacia e negociação por mecanismos coercitivos, como afirmou Patriota (1998, p.59): “a ideia de que o recurso mais desimpedido a formas militarizadas e coercitivas de preservação da paz internacional fortaleceria a Organização e o Conselho de Segurança está refletida em diversas postulações da Agenda para a Paz e poderia ser considerada um dos fios condutores do documento." Segundo Patriota (1998, p.58), o relatório confundia, deliberadamente, entre as formas pacíficas e coercitivas de solucionar diferendos ao estabelecer que o consentimento não era mais essencial para uma missão de manutenção da paz, a partir da frase: "peacekeeping is the deployment of a United Nations presence in the field, hitherto with the consent of all the parties concerned" (ONU, 1992, §20).

O parágrafo 17 do relatório (ONU, 1992), onde é anunciado “o fim da era da soberania absoluta e exclusiva", é entendido por Patriota como "um outro 
elemento nesse desenho geral de fortalecimento da capacidade de ação coercitiva, imposição da paz pela força, revisão do princípio do consentimento" (PATRIOTA, 1998, p.60). Ainda na análise do documento, Patriota (1998, p.59) salienta que no interior do subcapítulo sobre diplomacia preventiva "a importância atribuída à ideia do posicionamento preventivo de forças, [...] enfatizava a modalidade militarizada da prevenção em detrimento da diplomática”.

A política externa brasileira defendeu que a utilização do recurso da força não é garantia de que se consiga impor a paz; e o custo pode ser muito alto, como lembrou Patriota dos casos da Somália e da Bósnia (PATRIOTA, 1998, pp. 79-82, 192). Os custos a que se refere o diplomata são os riscos de vida inerentes a uma ação desse tipo (tanto das tropas das Nações Unidas como dos civis que se quer proteger), mas também ao fato de "que uma intervenção coercitiva determinada pelo Conselho de Segurança é sempre vista no país ou região alvo como um fato político, mesmo que se insista na sua justificativa humanitária" (PATRIOTA, p.80). Nesse sentido, Patriota (1998, p.60) salienta que as chamadas “operações de paz de segunda geração" expõem muito mais o pessoal da Organização a manifestações de hostilidades.

Sobre os desafios enfrentados na Somália, o Embaixador Celso Amorim declarou perante o plenário da $51^{\mathrm{a}}$ Assembleia Geral que:

a proliferação de situações de emergência humanitária exige uma definição da responsabilidade coletiva em face da fome, da doença, da brutalidade. [...] Os Estados membros devem tentar desenvolver um entendimento comum capaz de estabelecer quando a resposta internacional a essas situações pode ser deixada a cargo da Assembleia Geral, e quando o Conselho de Segurança precisa ser ativado em vista de aspectos especificamente da alçada da segurança internacional. Neste contexto, será necessário pensar em critérios passíveis de ajudarem a determinar quando uma situação ameaça a paz internacional [...] Se a segurança internacional parece ameaçada, mas a situação não é absolutamente clara, parâmetros objetivos deverão ser estabelecidos para determinar quando não são admissíveis medidas coercitivas. E quando a coerção for contemplada, e o consentimento das partes deixar de ser um requisito, sua cooperação deverá ser buscada, mesmo assim, por questão de princípio, já que sem esta cooperação as possibilidades de êxito serão reduzidas. ${ }^{22}$

Amorim chama a atenção para a necessidade de critérios claros para definir quando se constitui um caso de ameaça internacional para que o uso da

\footnotetext{
${ }^{22}$ Discurso pronunciado pelo Embaixador Celso Amorim no plenário da LI AGNU em 26.11.1996 apud PATRIOTA, 1998, pp. 81-82.
} 
força não fique banalizado, aumentando os riscos de ações unilaterais. Além disso, há um questionamento dos diplomatas brasileiros sobre a comprovação de que situações de emergência humanitária, de fato, ameaçam a paz internacional, afinal, "os problemas políticos e sociais da Somália não se alastraram aos países vizinhos e os econômicos são endêmicos na África" (PATRIOTA, 1998, p.80). Cabe ainda ressaltar que Amorim define responsabilidade coletiva como a responsabilidade da comunidade internacional no combate das raízes dos conflitos, ligadas ao subdesenvolvimento, "em face da fome, da doença [...] e do uso de medidas não coercitivas para combater a "brutalidade", as violações de direitos humanos ou do direito humanitário. E que, neste assunto, não seria preciso a ativação constante do Conselho de Segurança, já que nem sempre tais problemas constituem necessariamente uma questão "da alçada da segurança internacional”.

O Brasil defende que não há necessidade de atrelar temas humanitários, de direitos humanos, de propagação da justiça e de disseminação da democracia com o contexto das ameaças à paz e segurança internacionais (PATRIOTA, 1998, p.193). Para o governo brasileiro, como assinala Patriota, a promoção de tais valores não precisa ser feita através da ótica da segurança - mas pode ocorrer "por pressão internacional não militarizada ou mesmo pela arte da persuasão ou pela expectativa de ganhos econômicos e comerciais" (PATRIOTA, 1998, p.193). Mas apesar de não ser favorável a uma conexão automática entre crise humanitária e intervenção militar coercitiva, o diplomata abre uma exceção para os casos de genocídio: "com a exceção dos "worst case scenarios" como os casos de genocídio, não há porque favorecer o estabelecimento de uma relação automática entre crise humanitária e intervenção militar coercitiva” (PATRIOTA, 1998, p.193).

Mesmo assim, ele deixa claro que "nenhuma ação coercitiva pode prescindir de uma estratégia de pacificação política na qual inserir-se" (PATRIOTA, 1998, p.193) e finaliza com o seguinte argumento, defendido acima por Amorim: "trata-se, em suma, de distinguir entre responsabilidade coletiva e segurança coletiva no campo humanitário e dos direitos humanos" (PATRIOTA, 1998, p.194). Da mesma forma que Amorim, ele diferencia responsabilidade coletiva de segurança coletiva. A primeira pode ser exercida por medidas não coercitivas e deve ter como foco da ação: o combate às raízes do conflito 
(problemas econômicos e sociais); e a primazia da via diplomática para resolver controvérsias e combater violações de direitos humanos e do direito humanitário. E a segunda, a segurança coletiva, deve envolver uma avaliação criteriosa de cada caso por parte do Conselho de Segurança.

Em relação a Ruanda, Patriota esclarece a oposição brasileira à intervenção, destacando que os objetivos humanitários não pareciam ser a principal razão para a ação e que as autoridades do país não desejavam a presença da ONU:

[...] não era possível apoiar intervenção por uma força multinacional que carecia de representatividade para merecer este nome, cujos objetivos humanitários pareciam - na melhor das hipóteses - entremeados a cálculos políticos não declarados, e que não contava com o apoio dos países da região, além de ser frontalmente indesejada pelas autoridades que haviam assumido a liderança do país após terem sido vítimas de um genocídio (PATRIOTA, 1998, p.191, grifos nossos).

Ainda na análise de Uma Agenda para a Paz, Patriota (1998, p.59) também sinaliza a preocupação do governo brasileiro com o novo papel que a OTAN passa a assumir, "expressando a modalidade militarizada da prevenção em detrimento da diplomática". Além disso, o diplomata via com desconfiança o crescente envolvimento da OTAN em zonas de guerra fora de seu território de defesa (definido no Artigo $6^{\circ}$ do Tratado do Atlântico Norte), como ocorreu na exIugoslávia (PATRIOTA, 1998, p.97). Essa presença cada vez mais abrangente da OTAN levou o governo brasileiro e de outros países do Sul global, a uma maior resistência ao uso dos mecanismos coercitivos para fins humanitários, com receio de que fossem mal utilizados.

A publicação de "Uma Agenda para o desenvolvimento", em 1994, e dos Relatórios de Desenvolvimento Humano, desde 1990, em que se realiza um esforço para articular discursivamente paz durável e desenvolvimento, dando grande peso às atividades de reconstrução, demonstrava que o país se alinhava aos preceitos liberais da governança internacional no que concerne às práticas de peacebuilding. Contudo, o governo brasileiro entendeu que a questão do desenvolvimento estava sendo tratada de uma forma politizada, a partir da ótica da segurança - através de uma lógica de defesa/ameaça. Assim, Patriota (1998, p.60) afirma que o conceito de peacebuilding (consolidação da paz) "se distingue de 
uma promoção do desenvolvimento tradicional como se este fosse uma empreitada inspirada politicamente, vista através do prisma de uma preservação mais imediata da paz e da segurança”.

Além disso, o Brasil defendia que as atividades de consolidação da paz não deveriam se restringir à reconstrução pós-conflito e somente depois do encerramento da operação de manutenção da paz (retirada das tropas) (NEVES, 2009, p.21). Segundo Gilda Motta Neves (2009, p.21), o Brasil defendia, e ainda defende que as atividades de consolidação da paz também ocorram simultaneamente à manutenção da paz e que se desenvolvam mesmo onde ainda não houve - mas existe a possibilidade de que sobrevenha - conflito interno. Como foi apresentado no primeiro capítulo, o Secretário-Geral Boutros-Ghali tentou atender textualmente às reivindicações brasileiras, em seu Relatório Supplement to an Agenda for Peace, de 1995, apesar das dificuldades em operacionalizar tal ideia.

Segundo Patriota, o Brasil também afirmava que as atividades de desenvolvimento (relacionadas aos aspectos econômicos e sociais) não deviam ser tratadas pelo Conselho de Segurança - e sim por órgãos competentes das Nações Unidas para esta área - como a ECOSOC (Conselho Econômico e Social) (FONSECA JR, 2002, pp. 305-311). O governo brasileiro defendia a necessidade de se criar abordagens "que permitam um desengajamento gradual do Conselho de Segurança e o engajamento progressivo de outras instâncias deliberativas intergovernamentais com apropriada competência jurídica e substantiva" (FONSECA JR, 2002, p.310). Era uma advertência sobre o acúmulo de poder e de funções do Conselho de Segurança - "que não pode se considerar a solução para todos os problemas dos conflitos de natureza doméstica" (FONSECA JR, 2002, p.303). Celso Amorim destacou que "sem a assistência internacional significativa, de um tipo que o Conselho de Segurança não pode, jurídica ou materialmente, oferecer, não será realista contemplar a ideia de que a estabilização e a reconciliação são alcançáveis" (FONSECA JR, 2002, p.310). 


\section{A perspectiva brasileira na primeira intervenção no Haiti (1994)}

O Brasil se absteve na votação da resolução 940 (ONU, 1994a), na sessão de 31 de julho de 1994 do Conselho de Segurança, que aprovaria a primeira intervenção coercitiva no Haiti. Como aponta Patriota, isto se deveu ao não cumprimento das condições necessárias para uma intervenção justa e positiva:

No caso mais complexo do Haiti, o Brasil atuou em sintonia com o sentimento preponderante na América Latina ao procurar consignar na resolução que autorizaria a primeira intervenção coercitiva da ONU no Hemisfério à excepcionalidade das circunstâncias que a tornavam admissível. Não havendo sido possível fazê-lo, a abstenção constituiu a opção que, sem impedir o êxito da missão e o regresso do presidente legítimo a Porto Príncipe, simbolizou a adesão regional aos princípios da não ingerência em assuntos internos e solução pacífica de controvérsias, que continuarão a dominar o seu léxico diplomático, e fazem parte da Constituição brasileira (PATRIOTA, 1998, p. 192, grifos nossos).

O presidente constitucionalmente eleito, Jean-Bertrand Aristide, foi destituído por um golpe militar, em 30 de setembro de 1991, poucos meses depois de tomar posse (CÂMARA, 1998, p.9). Logo após o fato, o governo brasileiro aprovou, de acordo com a resolução 1080 (OEA, 1991), a iniciativa da convocação do Conselho Permanente da OEA, para que a situação fosse avaliada e as medidas necessárias fossem tomadas em defesa da democracia e dos direitos humanos, de acordo com a própria Carta da Organização (CÂMARA, 1998, p.165). Lembrando que o governo brasileiro interpretou a crise haitiana como sendo um problema de natureza eminentemente interna e, por isso, defendeu que se mantivesse:

a condução do assunto na esfera de competência do foro hemisférico; [a fim de] evitar que a Organização adotasse soluções ilegítimas ou inadequadas juridicamente, como a organização de uma força interamericana de paz ou a imposição de um bloqueio naval; e procurar assegurar que, no âmbito das Nações Unidas, a questão fosse debatida apenas no nível da Assembleia Geral, cujo envolvimento, se inevitável, deveria dar-se unicamente a título de apoio aos esforços regionais (CÂMARA, 1998, p.167, grifos nossos). 
Fernando Henrique Cardoso $^{\mathbf{2 3}}$ enfatizou a orientação da política externa brasileira, recomendando que "as decisões tomadas no âmbito da OEA reiterem a percepção de que o assunto, ao ser considerado pelas Nações Unidas, sirva para fortalecer a cooperação em bases harmoniosas, que deve existir entre as duas organizações, sem superposição de atribuições". ${ }^{24}$ Dessa forma, o país cooperou com a OEA de diferentes maneiras, incluindo a adoção das medidas de coerção. Aprovou no âmbito interno, por exemplo, uma legislação que tornava tais medidas obrigatórias em território nacional. Mas isso ainda fazia parte do que a política externa brasileira costuma chamar de "via negociada", que seriam pressões políticas, econômicas e comerciais contra o Haiti na esperança de que assim o governo haitiano voltasse atrás (CÂMARA, 1998, p.166).

O Brasil aprovou, no ano de 1993, a resolução 841 (primeira emanada do Conselho de Segurança sobre a crise haitiana), e ainda as resoluções 873 e 875 (Cf. ONU, 1993b, 1993a, 1993). As duas últimas resoluções previam um nível mais duro de sanções econômico-comerciais, incluindo até a possibilidade de bloqueio naval (CÂMARA, 1998, p.169). A adesão brasileira a tais resoluções era bastante significativa. A situação no Haiti estava ficando cada vez mais complicada, com manifestações constantes dos golpistas contra o desembarque da Missão das Nações Unidas para o Haiti (MINUHA) juntamente com ações violentas constantes contra observadores da Missão Civil Internacional e do Enviado Especial dos Secretários-Gerais da OEA e da ONU (CÂMARA, 1998, p.171). Dessa forma, parecia oportuno que o Conselho de Segurança adotasse "remédios igualmente únicos e excepcionais, com o propósito único e exclusivo de assegurar o respeito às sanções relativas a petróleo, derivados e armamentos contidas nas resoluções 841 e 873" (PERICÁS, 1993 apud CÂMARA, 1998, p.169).

Enquanto as medidas previstas pela ONU estavam dentro do modelo estabelecido pela OEA, mesmo em alguns momentos sendo um pouco mais rígidas, o Brasil as apoiou. Afinal, do ponto de vista brasileiro e da própria OEA, "as sanções haviam sido impostas para pressionar o governo ilegítimo a negociar

\footnotetext{
${ }^{23}$ FHC foi Ministro das Relações Exteriores do Brasil em 1992 e 1993 no governo de Itamar Franco.

${ }^{24}$ Nota de resposta ao Presidente da Reunião $A d H o c$ a respeito da proposta feita por Aristide para que o Conselho Permanente da OEA formalizasse um pedido de apoio às Nações Unidas. Arquivo do Itamaraty apud CÂMARA, 1998, p. 167.
} 
uma saída diplomática para a crise e não para preparar uma intervenção" (PATRIOTA, 1998, p.134). Mas, em 1994, o Chefe do Departamento de Assuntos Políticos e Militares do Departamento de Estado norte-americano, Thomas McNamara, apresentou em Brasília o projeto de resolução do Conselho de Segurança que previa a criação de uma força militar multinacional (com liderança americana) e a ampliação do número de integrantes e mandatos da MINUHA. O então Secretário-Geral das Relações Exteriores, Embaixador Roberto Abdenur, informou que "o país não favoreceria uma intervenção militar de caráter unilateral no Haiti, mas consideraria sua participação na MINUHA, desde que a ampliação da missão se desse em decorrência de mandato específico do Conselho de Segurança” (PATRIOTA, 1998, p.134).

O Brasil temia que uma intervenção no Haiti abrisse um precedente para justificar ações militares no futuro em situações de crise interna em outros países (PATRIOTA, 1998, p.171). Para completar, os países da América Latina não entraram em um consenso sobre a proposta, em um momento em que o Brasil participava como membro não permanente do Conselho de Segurança. ${ }^{25}$ Dessa forma, a delegação brasileira se absteve na votação da resolução 940 (ONU, 1994a), que autorizava uma força multinacional com base no Capítulo VII:

to use all necessary means to facilitate the departure from Haiti of the military leadership, consistent with the Governors Island Agreement, the prompt return of the legitimately elected President and the restoration of the legitimate authorities of the Government of Haiti [...] (ONU, 1994a, §4).

Segundo Celso Amorim, Ministro das Relações Exteriores (1993-1995), "preferimos nos abster, porque, naquele momento, nos pareceu um precedente perigoso para outras situações que havia no próprio Caribe - inclusive em Cuba. Naquela época, a tensão entre os Estados Unidos e Cuba ainda estava muito aguda, de modo que preferimos nos abster" (AMORIM, 2011, p.37). Tal justificativa tinha fundamento para além da tradição não intervencionista do governo brasileiro. Os problemas internos no Haiti e em Cuba, em particular, geraram um aumento no fluxo de migração para os Estados Unidos - o que foi

\footnotetext{
${ }^{25}$ No hemisfério, os países partidários da intervenção militar eram: EUA apoiados pela Argentina e pelos caribenhos anglófonos. Enquanto Brasil, Cuba, México, Uruguai e Venezuela se oporam a esta solução publicamente na sessão de 31 de julho de 1994 do Conselho de Segurança, quando foi adotada a resolução 940. Brasil e China se absteram (Cf. PATRIOTA, 1998, p. 129; CÂMARA, 1998, p. 171).
} 
interpretado pelo governo americano como uma ameaça por um período (HERZ, 2002). Estima-se, inclusive, que mais de 20 mil haitianos foram levados para a base de Guantánamo pelo governo americano, o que foi visto como um impulso para que os Estados Unidos agisse de forma rápida (HERZ, 2002). Nesse sentido, Mônica Herz alertou que

o problema gerado pelo fluxo de migrantes haitianos foi uma variável relevante para que se tomasse a decisão de intervir militarmente naquele país e tornou-se um tema importante da campanha eleitoral que levaria Clinton à Casa Branca. O estabelecimento de um governo constitucional no Haiti permitia aos Estados Unidos recusar aos haitianos o status de refugiados ou exilados"(HERZ, 2002, grifos nossos).

Para o governo brasileiro, a intervenção no Haiti, em 1994, teve um caráter, "de fato, unilateral, ferindo assim os compromissos de não intervenção, consagrados pelo Estado brasileiro no artigo $4^{\circ}$ de sua Constituição e nas Cartas da OEA e da ONU" (CÂMARA, 1998, p.171). Segundo a avaliação da Missão do Brasil junto à ONU, esse era exatamente o receio dos países em desenvolvimento, que "por verem com natural reserva a ampliação da capacidade intervencionista da ONU, quase sempre exercida em cenários meridionais, optaram de modo geral (no debate geral da AGNU) por formulações de apoio genérico, cautelosas ou matizadas à Agenda para a Paz". ${ }^{26}$

Para Patriota (1998, p.7), o tratamento do caso do Haiti, como o da Somália e o de Ruanda, através do Capítulo VII da Carta, podia ser percebido como "a expressão de um processo não sistemático de articulação de um novo paradigma de segurança coletiva por decisões ad hoc do Conselho de Segurança [...]". O Brasil defendeu, nas diversas instâncias em que a Agenda para a Paz do Secretário-Geral foi discutida, "um multilateralismo orientado para a construção de uma ordem internacional mais justa, respeitosa do direito internacional, democrática, tolerante e não violenta". E promoveu "[...] o conceito de "construção da paz preventiva" ("preventive peace-building"), por intermédio de ações de fomento do progresso econômico e social, [conseguindo] mobilizar o Secretariado e os Estados membros na elaboração e discussão de uma "agenda para o desenvolvimento" (PATRIOTA, 1998, p.65).

\footnotetext{
${ }^{26}$ Telegrama Confidencial de DELBRASONU no ${ }^{\circ} 2417$ de 17.10.92 apud PATRIOTA, 1998, p.
} 65. 
Em resumo, Paulo Esteves destaca que os esforços do Brasil em relação aos arranjos de segurança coletiva ao longo dos anos noventa, e, particularmente, em direção às operações de paz foram:

i) conter qualquer avanço na agenda intervencionista; ii) enfatizar a necessidade do consentimento entre as partes; iii) fortalecer os instrumentos pacíficos e diplomáticos disponíveis para a resolução de conflitos; iv) ter uma postura crítica diante da proeminência da agenda do Conselho de Segurança, em geral, e de sua absorção das agendas humanitárias e de desenvolvimento, em particular e; v) combater as raízes dos conflitos identificadas com os problemas de desenvolvimento - por meios cooperativos em detrimento dos meios militares (ESTEVES, 2012b, p.6, grifos nossos).

Mas a questão, como aponta Carlos Santiso (2000), é que se o Brasil queria ocupar uma posição mais influente no cenário internacional, precisaria de uma estratégia mais assertiva diante dos conflitos e dilemas que o mundo estava enfrentando. A seção seguinte tem como principal objetivo salientar as descontinuidades entre os governos de FHC e de Lula que permitiram a participação do Brasil no comando da MINUSTAH e um maior engajamento do país com a R2P. Cabe ressaltar, de início, que é no campo do desenvolvimento que o país buscará exercer liderança no plano global e, por isso, a participação brasileira na criação da Comissão para Consolidação da Paz (Peacebuilding Commission) será destacada. O próximo capítulo se baseia em duas hipóteses de trabalho: 1- que a adoção do conceito da "não indiferença" como alternativa ao princípio da "não intervenção" parece alinhar o país aos preceitos liberais da governança internacional no que concerne às práticas de peacebuilding e permite o Brasil resistir aos avanços desses preceitos no que diz respeito ao problema da intervenção; 2- que a apropriação do conceito de "não indiferença", contudo, cria a possibilidade do país diferenciar-se em relação aos países do Norte ao enfatizar sua experiência em lidar com os problemas de combate à fome e à pobreza. 


\section{Capítulo 3 - O Brasil e o campo da segurança: uma nova proposta}

A busca de maior projeção internacional a partir da condução de uma política externa mais flexível pode ser considerada a principal estratégia do governo de Luiz Inácio Lula da Silva (2003-2010), especialmente em seu segundo mandato. O desenvolvimento ainda aparece como uma forma de alcançar a autonomia. Mas isso será perseguido através de um caminho bastante inovador. A ênfase dada pelo governo aos projetos domésticos de combate à pobreza e à miséria transcende para o plano global como uma demonstração de capacidade do país. Capacidade de liderar projetos internacionais na área de desenvolvimento, capacidade de contribuir decisivamente no debate sobre normas e princípios que estejam vinculados com este tema, e capacidade de ser um ator importante em um contexto de reforma institucional da ONU. A autonomia é priorizada através de uma "política desenvolvimentista ativa", em que se procura "a colaboração com países com interesses similares" (LIMA; HIRST, 2009, p.49) e a articulação de "um projeto nacional focado em superar os desequilíbrios sociais domésticos" (LIMA; HIRST, 2009, p.49).

Analistas e diplomatas costumam afirmar que tanto o governo de Fernando Henrique Cardoso quanto o governo de Lula agem em conformidade com a denominada "tradição diplomática brasileira" que, em resumo, busca "desenvolver economicamente o país, preservando, ao mesmo tempo, certa autonomia política" (VIGEVANI; CEPALUNI, 2007) Mas essa identificação pode não ser muito útil para entender a participação do Brasil na Missão de Estabilização das Nações Unidas para o Haiti (MINUSTAH) ou na proposta brasileira recentemente dentro do debate da R2P. Compreender as descontinuidades e as especificidades que permitiram uma mudança de postura da política externa no governo Lula é o motor deste capítulo - que tratará, a partir do discurso diplomático, da participação do Brasil no comando da MINUSTAH e da reação brasileira à $\mathrm{R} 2 \mathrm{P}$, incluindo a ideia de Responsabilidade ao Proteger. Ademais, será analisada a participação brasileira na criação da Comissão de Peacebuilding como parte da estratégia do país em exercer liderança no campo do desenvolvimento. Ressalte-se que o significado de autonomia e desenvolvimento mudou consideravelmente nos dois governos (FHC e Lula), uma vez que 
apresentam "diferenças nas ações, nas preferências e nas crenças, buscando resultados específicos muito distintos no que diz respeito à política externa [...]" (VIGEVANI; CEPALUNI, 2007, p.275).

Kai Kenkel identifica dois fatores principais para a abertura gradual da política externa brasileira à R2P: um externo e um interno. O externo está relacionado à tradição multilateralista brasileira: a aprovação da R2P no Documento Final da Cúpula Mundial de 2005 (em inglês, World Summit Outcome Document) impulsionou uma reaproximação do Brasil com o conceito, uma vez que o governo se viu em um possível contexto de isolamento. Isso poderia ocasionar a perda de participação e influência nos debates sobre o tema (KENKEL, 2012a, p.2). E o interno se refere à aspiração do país por um papel mais relevante no âmbito global, especialmente dentro de organismos internacionais, como as Nações Unidas (KENKEL, 2008, p.7). E isso inclui a possibilidade de o Brasil ocupar um assento permanente dotado de poder de veto em um Conselho de Segurança reformado. Desse modo, pode-se dizer que o status do Brasil como uma potência emergente implicou ampliação do horizonte de expectativas e do espaço de experiência da política internacional brasileira (KOSELLECK, 2006).

As posições oficiais brasileiras com relação à R2P podem ser entendidas a partir do paradigma do institucionalismo pragmático, proposto por Letícia Pinheiro, e tratado no segundo capítulo. Em um primeiro momento, houve uma intencional baixa institucionalização, que gradualmente tem se transformado em maior comprometimento com essa norma e seus princípios, apesar das ressalvas. O interessante é perceber que a mudança de postura a partir do governo Lula está permitindo que o Brasil continue resistindo aos preceitos de intervenção e uso da força, ao mesmo tempo em que se engaja à $\mathrm{R} 2 \mathrm{P}$ e às práticas internacionais relacionadas com a intervenção (com a participação na MINUSTAH). Isso significa uma participação mais ativa nos debates, que culmina na recente proposta, a Responsabilidade ao Proteger.

A participação do Brasil na MINUSTAH também pode ser vista como uma estratégia para exercer liderança através da elaboração de uma nova abordagem para as operações de paz, em que o desenvolvimento seja o elemento norteador de toda a ação, restringindo assim o campo da segurança e de ação do Conselho de Segurança da ONU (CSNU). Responsabilidade seria definida 
separadamente do uso da força, iluminando os efeitos dessa tensão. Defende-se aqui a ideia de que o governo brasileiro aceitou participar de uma operação baseada no Capítulo VII da Carta para que - de dentro de uma prática intervencionista - o país consiga propor nova abordagem menos focada no uso da força.

O governo brasileiro tenta demonstrar na MINUSTAH como seria possível essa nova abordagem, priorizando elementos de desenvolvimento desde o início da operação. Entende-se por desenvolvimento sustentável a promoção dos direitos humanos - econômicos, políticos, civis e culturais (BRASIL, 2010). Percebe-se, após sete anos de missão, a necessidade de: i) identificar os sucessos e as falhas da operação a partir dos objetivos iniciais postos pelo governo brasileiro; ii) sistematizar essa nova abordagem de operações de paz de forma que ela possa ser replicada em outros países fora da região (KENKEL, 2010).

Entretanto, cabe notar que apesar de o Brasil se identificar como "crítico" à abordagem securitária das operações de paz, defendendo a inclusão do desenvolvimento nos debates de segurança, o país não parece ter como objetivo oferecer alternativas ao atual sistema de governança global, "seeking instead increased status within the established system" (HERZ, 2011, p.27) Segundo Mônica Herz, pode-se dizer que o Brasil busca a convergência de sua política com as normas internacionais, embora procure igualmente transformar tais normas, a partir das margens. À luz do alcance de maior status no cenário global, o país busca demonstrar que pode contribuir de maneira singular e decisiva, a partir de sua tradição pautada na mediação e na participação ativa nos debates da ONU, sendo assim, um forte candidato a um assento permanente no CSNU. Mônica Herz (2011, p.19) ressalta que os diplomatas brasileiros acreditam que o país possui "a special capacity to be competent negotiators, mediators or facilitators and to find the way to reach peaceful solutions to conflicts has become a relevant part of the country's international identity."

Mesmo havendo controvérsias se a intervenção no Haiti foi feita sob a orientação da R2P, é inegável a relação entre os dois eventos. E a postura brasileira nos dois casos está associada ao crescente desejo do governo Lula - e 
agora da presidenta Dilma Rousseff ${ }^{27}$ - em alcançar um papel internacional mais significativo, transformando a nova influência econômica do país em influência política internacional - particularmente na forma de um assento permanente no Conselho de Segurança, conforme declaração de Celso Amorim:

It is within this context that Brazil's aspirations for an enlarged Security Council with new members, permanent and non-permanent, with developed and developing countries in both categories should be seen. Brazil has already indicated its willingness to assume immediately its responsibilities as a permanent member, alongside other countries that are equally capable of acting on the global level and contributing to international peace and security. (AMORIM, 2005, p.12 apud KENKEL, 2012a, p.13, grifo nosso).

A questão que vem sendo colocada para o país, como um dilema típico de uma potência emergente, segundo Kenkel (2008), é que para assumir um papel de global player, o Brasil precisa flexibilizar princípios e ações que são tradicionais na sua política externa, cujas raízes estão vinculadas à região onde se encontra. A adesão ao conceito de "não indiferença" parece ser uma tentativa de resolver esta tensão sem ter que assumir uma posição mais assertiva sobre o tema da intervenção. Seria um "caminho do meio". A adoção desse conceito é uma demonstração da reformulação das prioridades nacionais. Enquanto a Política de Defesa Nacional (PDN), de 1996, estabeleceu que o Brasil devesse "participar de operações internacionais de manutenção da paz, de acordo com os interesses nacionais" (BRASIL, 1996), a PDN de 2005 orienta que o país deve "dispor de capacidade de projeção de poder, visando à eventual participação em operações estabelecidas ou autorizadas pelo Conselho de Segurança da ONU" (BRASIL, 2005). Além disso, o documento assinala que "para ampliar a projeção do País no concerto mundial e reafirmar seu compromisso com a defesa da paz e com a cooperação entre os povos, o Brasil deverá intensificar sua participação em ações humanitárias e em missões de paz sob a égide de organismos multilaterais" (BRASIL, 2005).

O ponto é que maior responsabilidade na manutenção da paz e de segurança internacionais é interpretada pelo governo brasileiro de uma forma distinta dos países do Norte. Para estes, responsabilidade está ligada à necessidade

27 A Presidenta foi eleita para o período de 2011 a 2014. Neste caso, o trabalho focará na continuidade entre os governos Lula e Dilma, mas reconhecendo que há uma série de importantes mudanças. 
de um engajamento com as intervenções humanitárias e com a R2P, principalmente no que concerne ao uso da força. Para o Brasil, o foco dessa responsabilidade está justamente no esforço em evitar medidas coercitivas, valorizando uma abordagem menos impositiva e mais "desenvolvimentista". Por isso, o país se encontra em uma situação delicada. Almeja ter um papel mais proeminente no cenário global, exercendo liderança no campo do desenvolvimento, mas, para isso, precisa se comprometer com as intervenções humanitárias, uma vez que os países mais poderosos do globo entendem que esse comprometimento é fundamental para exercer liderança.

\section{O Brasil e a MINUSTAH (2004)}

\section{Crise Haitiana: breve histórico ${ }^{28}$}

O Haiti é uma ex-colônia da França e foi o primeiro Estado do Caribe a obter independência, em 1804, sendo a primeira república liderada por negros no mundo. Sob ditaduras violentas há várias décadas - como as de François "Papa Doc" Duvalier (1957-1971) e de seu filho, Jean-Claude, o "Baby Doc" (19711986) - o país se tornou a nação mais pobre das Américas. Em fevereiro de 1986, o Haiti passou a ser administrado por uma junta chefiada pelo General Henry Namphy. O governo provisório enfrentou sérios problemas de ordem política, econômica e social, aprofundadas durante o período da "dinastia" Duvalier. Em 1988, as eleições consagraram a vitória do candidato da situação, Leslie Manigat, que logo sofreria um golpe de Estado liderado pelo General Henry Namphy. Em setembro, novo golpe de Estado, promovido pelo General Porsper Avril, depôs Namphy. Avril acabou sendo destituído em março de 1990. Nesse ano, instalou-se um governo transitório, liderado pela juíza Ertha Pascal-Trouillot, que convocou eleições para dezembro de 1990. As eleições presidenciais foram vencidas por Jean-Bertrand Aristide, que acabou destituído por um golpe militar liderado pelo general Raoul Cédras, em 30 de setembro de 1991, poucos meses depois de tomar posse. Nesse período, o Haiti é ocupado por uma força multinacional, liderada pelos Estados Unidos.

${ }^{28}$ Cf. FILHO, 2007. pp.141-151. 
Aristide reassume a presidência e após completar seu mandato, René Préval ganhou as eleições e governou por cinco anos (1995-2001). Nesse período, o quadro político deteriorou-se com a acentuação da divisão entre as forças políticas, inclusive no âmbito parlamentar. A eleição que se seguiu ocorreu em clima de desconfiança. Jean-Bertrand Aristide ganha com ampla maioria, apesar de protestos e boicotes da oposição. Em 2004, a forte oposição ao então presidente, somada à grave crise social e econômica do país, resultou em um confronto político entre oposição e governo que acabou se desdobrando em ondas de violência. O Governo Transitório foi assumido, conforme previsto na Constituição de 1987, pelo então presidente da Corte Suprema, Boniface Alexandre, nomeando Gérard Latortue como primeiro-ministro. Nesse período foi aprovada a Resolução 1529 (ONU, 2004c), que criava a Força Multinacional Provisória (Multinational Interim Force - MIF), composta por tropas americanas, chilenas e francesas com objetivo, entre outras coisas, de afastar a possibilidade de um golpe militar em gestação. O Brasil não aceitou enviar tropas por entender que esta era uma missão baseada no Capítulo VII, que tinha o objetivo de impor a paz. No entanto, em 30 de abril de 2004, o Brasil aceitaria participar do mandato da Resolução 1542 (ONU, 2004a) aprovada pelo Conselho de Segurança.

\section{A MINUSTAH}

A participação do Brasil na Missão de Estabilização das Nações Unidas para o Haiti (MINUSTAH), em 2004, pode ser compreendida a partir do institucionalismo pragmático: como uma estratégia para garantir a posição de liderança dentro da região e, consequentemente, aumentar o poder de barganha extrarregional. "Nesse sentido, esta que seria a estratégia da busca pela autonomia pela liderança, é relacional, ou seja, garante a liderança no entorno sul-americano e, simultaneamente, contribui para obter mais autonomia no plano global" (PINHEIRO, 2000, p.323). A crise haitiana configurava uma situação de visibilidade para a pretensão brasileira de obter um assento permanente no Conselho de Segurança das Nações Unidas. O discurso da diplomacia brasileira também alegou esta ser uma oportunidade de fortalecimento de uma identidade latino-americana e caribenha - que contribuía para a construção de uma agenda comum de desenvolvimento. $\mathrm{O}$ apoio ao multilateralismo também foi destacado 
pelo Ministro das Relações Exteriores, Celso Amorim, em declaração à revista The Economist: “[...] you can't support multilateralismo and when it comes to act say it's too dangerous" (FILHO, 2007, p.170).

Cabe ressaltar, porém, que esse movimento tem uma peculiaridade: a constatação que a Resolução 1542 (ONU, 2004a) estabelece a MINUSTAH como uma missão baseada no Capítulo VII, ou seja, um mandato de imposição da paz (peace enforcement). De fato, sem qualificar o Haiti indevidamente como um caso de R2P, há um amplo reconhecimento de que esta é uma intervenção chamada pela "responsabilidade de reagir" (KENKEL, 2012a, p.26). Para Kai Kenkel (2012a, p.26), a participação proeminente do Brasil em tal missão é uma ruptura clara com a política de manutenção da paz (peacekeeping) até então adotada pelo país. O autor completa que "não há dúvidas sobre a natureza robusta entre aqueles que estão familiarizados com a implementação de fato do mandato" (2012a, p.25). Entretanto, o governo brasileiro tem se esforçado para demonstrar que a missão não foi aprovada conforme o comando do Capítulo VII, como bem salientou Diniz:

The interpretation of the Brazilian government is that there is no inconsistency. In Resolution 1529, the reference to the fact of the Security Council "acting under Chapter VII" of the Charter is already made in the preamble to the Resolution, whereas in Resolution 1542 this reference to Chapter VII of the Charter is made only in paragraph 7 which would indicate, in the interpretation of the Brazilian government, that only this paragraph of Resolution 1542 is based on Chapter VII and not the whole resolution. According to this interpretation, therefore, MINUSTAH would not be based on Chapter VII and would be a peacekeeping operation (DINIZ, p. 92 apud KENKEL, 2008, p.47).

Antes de analisar este debate, é importante apresentar o que está escrito na Resolução 1542 . O parágrafo $4^{\circ}$ estabelece que:

4. Decides that MINUSTAH will consist of a civilian and a military component in accordance with the Secretary-General's report on Haiti (S/2004/300): a civilian component will include a maximum of 1,622 Civilian Police, including advisers and formed units and a military component to include up to 6,700 troops of all ranks; and requests further that the military component report directly to the Special Representative through the force commander [...] (ONU, 2004a, grifos nossos). 
O texto menciona que a MINUSTAH foi criada a partir do Relatório apresentado pelo Secretário-Geral no Haiti. Por isso, para que fique mais fácil avaliar se a MINUSTAH é ou não uma missão aprovada de acordo com o Capítulo VII, é interessante analisar o texto desse Relatório. Nele, o Secretário apresenta as características necessárias da futura missão para que se alcance a paz e a estabilidade no Haiti. Sobre o componente militar, o texto sugere que esta missão seria uma imposição da paz (peace-enforcement) porque "the Haitian authorities have been unable to address abuses effectively due to, inter alia, the weakness of State institutions in charge of guaranteeing respect for human rights and administering justice" (ONU, 2004). Isso indicaria que a questão do consentimento, neste caso, não é tão relevante, uma vez que o Haiti apresentava uma estrutura estatal bastante frágil. Além disso, o Relatório afirma que a Missão deveria ser multidimensional e ajudaria o Haiti, entre outras questões, a atingir a paz e a estabilidade. Esse não é um mero detalhe. Afinal, as missões de manutenção da paz, como o nome mesmo explica, são missões que têm o objetivo de manter uma paz que já existe. Se um dos objetivos passa a ser atingir a paz, através do uso de força militar, isso é indicativo de uma missão de peaceenforcement.

72. The Mission would be multidimensional and would help Haiti address a complex range of issues in a sustainable manner, achieve peace and stability, build and strengthen functioning democratic institutions; support the reestablishment of the rule of law; and promote social and economic development, as well as good governance. The Mission would conduct these activities in close cooperation and coordination with the Haitian authorities at the national, regional and local levels, as well as with the civil society actors and the population at large. (ONU, 2004, p.22, grifos nossos).

Na página 29 do Relatório, no item intitulado "Componente Militar", o Secretário também indica que esta missão deveria ser "robusta", com capacidade militar suficiente para lidar com as ameaças durante a implementação do mandato.

105. In the light of the continuing volatile security situation, including the proliferation of arms in Haiti, the Mission would operate under robust rules of engagement with sufficient capacity to be able to deal with threats to the implementation of its mandate (ONU, 2004, p.29, grifo nosso). 
Nesse contexto, a Resolução 1542 , no parágrafo $7^{\circ}$, explicita que um dos elementos da MINUSTAH, relacionado à paz e à segurança, estaria baseado no Capítulo VII, conforme está a seguir:

\section{Acting under Chapter VII of the Charter of the United Nations with regard to Section I below, decides that MINUSTAH shall have the following mandate:}

I. Secure and Stable Environment:

(a) in support of the Transitional Government, to ensure a secure and stable environment within which the constitutional and political process in Haiti can take place (b) to assist the Transitional Government in monitoring, restructuring and reforming the Haitian National Police, $[\ldots](\mathrm{c})$ to assist the Transitional Government, particularly the Haitian National Police, with comprehensive and sustainable Disarmament, Demobilization and Reintegration (DDR) programmes [...](d) to assist with the restoration and maintenance of the rule of law, public safety and public order in Haiti through the provision inter alia of operational support to the Haitian National Police and the Haitian Coast Guard, as well as with their institutional strengthening, including the re-establishment of the corrections system;(e) to protect United Nations personnel, facilities, installations and equipment and to ensure the security and freedom of movement of its personnel, taking into account the primary responsibility of the Transitional Government in that regard; (f) to protect civilians under imminent threat of physical violence, within its capabilities and areas of deployment, without prejudice to the responsibilities of the Transitional Government and of police authorities; (ONU, 2004a, grifos nossos).

A liderança do país na MINUSTAH se deu com base em uma postura identificada pela diplomacia brasileira como "não indiferença". Esta que seria uma noção complementar ao princípio de não intervenção (AMORIM, 2011, p.37). A noção de "não indiferença" surge no contexto africano após o episódio trágico de Ruanda, em 1994. Durante o massacre, a Organização da Unidade Africana (OUA) alegou não poder interferir nos assuntos internos dos países por estes serem soberanos em suas decisões. Contudo, como alerta Ricardo Seitenfus (et al, 2007, p.11), "aí se constata aquela que talvez seja a mais grave debilidade do Direito Internacional contemporâneo pensado e institucionalizado desde e para os países desenvolvidos". Para o autor, Cilliers e Sturman apresentam bem essa ideia:

The concept of State sovereignty, on which the international system and the OUA were founded, presumes that each state has the power, authority and competence to govern its territory. For many African States, however, sovereignty is a legal 
fiction that is not matched by governance and administrative capacity (CILLIERS; STURMAN, 2002 apud SEITENFUS et al, 2007, p.11).

Segundo Seitenfus (et al, 2007, p.11), esta consciência associada a outros fatos de violações graves de Direitos Humanos levaram a busca por um novo modelo de integração regional, respaldado por uma cultura securitária alternativa. O primeiro movimento foi a substituição, em 2002, da Organização da Unidade Africana pela União Africana (UA), que simbolizou a busca por soluções aos problemas enfrentados pelo continente a partir da realidade e necessidades locais. Essa nova cultura securitária inclui a superação da doutrina de não intervenção, "necessária nos anos 60 a 80, quando se davam os processos de descolonização no continente, mas incapaz de atender às demandas da nova época" (SEITENFUS et al, 2007, p.12). Passa-se, então, a trabalhar com a noção de "não indiferença", que "tem suas raízes no conhecimento popular africano que afirma não ser possível desviar os olhos enquanto a casa de um vizinho está em chamas" (SEITENFUS et al, 2007, p.12).

Diferentemente do caso brasileiro, o conceito de "não indiferença" foi institucionalizado na África e transposto para o Acto Constictutivo da União Africana. Tal conceito passou a ser considerado uma doutrina. No caso africano, a "não indiferença" respalda a intervenção em um Estado Africano em duas circunstâncias:

a) mudanças inconstitucionais de governo (art. $4^{\circ}$, "p" da Carta da UA), essencialmente no que diz respeito aos frequentes golpes de Estado levados a cabo em solo africano [...]; e b) Intervenção humanitária nas chamadas “circunstâncias graves", entre as quais figuram crimes de guerra, genocídios

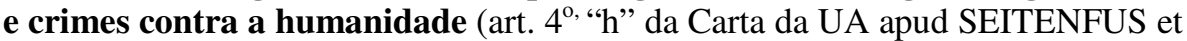
al, 2007, p.12, grifos nossos).

Além disso, a iniciativa da intervenção poderá partir: “a) de decisão da Assembleia Geral da UA ou, b) da solicitação de um Estado Membro" (SEITENFUS et al, 2007, p.12). Uma vez que a intervenção seja aprovada, o Conselho de Segurança e Paz, criado no âmbito da UA, ficará responsável por implementar e supervisionar a operação. O Conselho deverá agir a partir das diretrizes estabelecidas pelo Relatório elaborado pela Comissão Internacional 
sobre Intervenção e Soberania Estatal (ICISS), produzido em 2001, acerca do conceito de "Responsabilidade de Proteger" (SEITENFUS et al, 2007, p.12).

Nesse contexto, a noção de não indiferença está ligada à possibilidade da superação do princípio da não intervenção nos casos em que Estados não cumpram com seu dever de garantir proteção e bem-estar aos cidadãos porque "a inviolabilidade dos limites dos Estados não deve ser defendida com maior intensidade do que a vida e a dignidade de seus habitantes" (SEITENFUS et al, 2007, p.12).

A tradução feita pela política externa brasileira da noção de "não indiferença" ainda é nebulosa e paradoxal. Segundo Amorim, "o respeito pela autodeterminação em conjunção com a decisão de ajudar aqueles extremamente necessitados é o que chamamos de "não indiferença", princípio que não afeta a não intervenção, mas traz nova perspectiva sobre ela" (BRASIL, 2010). Essa nova perspectiva salientada por Amorim está relacionada com "o compromisso expresso do Governo Lula com a inclusão social e sua política de eliminação do problema da fome endêmica e da pobreza absoluta" (LIMA, 2005) Compromisso que não se limita à esfera nacional, pois

a mesma aspiração por desenvolvimento e progresso social, que moldam a ação governamental em âmbito interno, nos mobilizará nos planos regional e global. Nossa aspiração por paz e solidariedade passa necessariamente por uma atenção detida para as carências dos menos favorecidos (AMORIM, 2003, p.160 apud SEITENFUS, 2007, p.19, grifo nosso).

A fala de Celso Amorim revela que o conceito de "não indiferença" é apropriado pela política externa brasileira como uma forma de explicar e legitimar essa nova atitude, pautada pelo princípio da solidariedade e da responsabilidade, frente aos desafios contemporâneos. Responsabilidade é entendida, prioritariamente, como a necessidade de ação - por medidas não coercitivas - para assistência a um país com grandes dificuldades econômicas e sociais. Segundo o ex-chanceler:

É muito importante que todos nós sejamos capazes de praticar a não indiferença, isto é, um engajamento no auxílio sempre que solicitado, para a consolidação democrática dos países. Mas, ao mesmo tempo, também é importante nos abstermos de interferir em processos internos. É isso que tem guiado a política do Presidente Lula, baseada na integração, baseada na 
amizade, baseada na não indiferença, mas também na não intervenção (BRASIL, 2006 apud SEITENFUS, 2007, p. 19, grifos nossos).

A diplomacia brasileira pauta-se pelo Princípio de Não Ingerência em assuntos internos, consagrado em nossa Carta. O governo do Presidente Lula tem associado a esse Princípio básico uma atitude que descrevemos como de "não indiferença". Temos prestado nosso apoio e solidariedade ativos em situações de crise, sempre que somos solicitados e consideramos ter um papel positivo" (BRASIL, 2005 apud SEITENFUS, 2007, p. 19, grifos nossos).

Celso Amorim afirma que o Brasil só aceitou participar da MINUSTAH "porque fomos procurados de maneira muito insistente e por vários atores [...] desde que a força fosse aprovada e estabelecida pelo Conselho de Segurança" (AMORIM, 2011, p.38). No entanto, mesmo sendo uma operação de paz estabelecida pelo Conselho de Segurança, o que lhe deu legitimidade, a MINUSTAH foi aprovada baseada no Capítulo VII da Carta das Nações Unidas, situação que sempre criou resistência no governo brasileiro. De fato, em nenhum momento houve no Haiti um cessar-fogo. Pelo contrário, quando a missão foi criada, as gangues que desestabilizavam o país não haviam concordado em se desarmar (NETO, 2010, p.36). Portanto, a decisão brasileira de participar da operação de 2004 no Haiti pode ser considerada paradoxal, uma vez que o país continua defendendo o princípio da não intervenção. Amorim tenta explicar essa decisão:

No caso do Haiti há uma mescla: há uma Resolução do Capítulo VI com elementos do Capítulo VII. Isso permitiria que a missão a ser comandada pelo Brasil fosse mais "robusta", como se costuma dizer, e que pudesse empregar a força quando necessário. Essa talvez tenha sido a principal diferença entre a operação no Haiti e as anteriores em que o Brasil esteve envolvido (AMORIM, 2011, p.39, grifos nossos).

O Capítulo VI da Carta refere-se a solução pacífica de controvérsias. Nesse Capítulo, fica claro que o uso de uma força de interposição é permitido apenas com o intuito de manutenção da paz. O artigo $36 \S 2^{\circ}$ esclarece que "o Conselho de Segurança deverá tomar em consideração quaisquer procedimentos para a solução de uma controvérsia que já tenham sido adotados pelas partes" (ONU, 1945, grifo nosso). Só que no caso do Haiti, como foi dito anteriormente, "a missão pode ser entendida como uma missão de imposição da paz [...]" 
(NETO, 2010, p.36), já que não houve um acordo entre as partes, nem um cessarfogo. A operação foi aprovada com base no Capítulo VII, apesar de também possuir elementos do Capítulo VI, porque também envolvia ações de manutenção da paz tradicional e estabilização, caracterizando uma missão multidimensional.

Em resumo, as funções da MINUSTAH, de acordo com a resolução 1542 (ONU, 2004a), se dividem em três áreas: criação de um ambiente seguro e estável, garantia do respeito aos direitos humanos e apoio ao processo político no Haiti. O mandato também demandava, em um momento pós-conflito, que os Estados Membros participantes da operação fornecessem assistência substancial às necessidades humanitárias "to permit the reconstruction of the country, utilizing relevant coordination mechanisms, and further calls upon States, in particular those in the region [...]" (ONU, 2004a, § 15, grifo nosso).

A principal motivação do envolvimento brasileiro na MINUSTAH parece estar relacionada com o fato de o mandato incluir atividades de reconstrução, ou peacebuilding - o que deve englobar desenvolvimento social e econômico na busca pelo fim da pobreza (ONU, 2004a, § 13). ${ }^{\mathbf{2 9}}$ Isso criava a possibilidade do país exercer um papel de liderança, uma vez que o governo do Presidente Lula foi marcado pelo sucesso dos programas sociais e pela luta contra a miséria. A participação brasileira no comando da Missão, “might be a shift in Brazil's position towards peace-enforcement" (ESTEVES, 2012b, p.7). Essa mudança só foi possível pela adoção do conceito de "não indiferença", que passa a estar relacionado com a busca por uma atitude solidária diante dos problemas sociais dos outros países, especialmente para as questões de fome e pobreza - que geram conflitos e sofrimento à população.

Pode-se ressaltar que as novas disposições do país em exercer um papel mais protagônico tanto no continente quanto na arena internacional tinham como foco o campo do desenvolvimento, o que também significava "construir capacidade de influência na elaboração de normas e padrões globais e regionais de modo a torná-los mais permeáveis aos interesses dos países do Sul” (LIMA, 2005,

\footnotetext{
${ }^{29}$ O Conselho de Segurança no parágrafo 13 da Resolução 1542 “emphasizes the need for Member States, United Nations organs, bodies and agencies and other international organizations, in particular OAS and CARICOM, other regional and subregional organizations, international financial institutions and non-governmental organizations to continue to contribute to the promotion of the social and economic development of Haiti, in particular for the long-term, in order to achieve and sustain stability and combat poverty" (ONU, 2004a, grifos nossos).
} 
p.17). Segundo Amorim, a participação brasileira na MINUSTAH abria "a possibilidade de exigirmos ações para promover o desenvolvimento e a reconstrução do Haiti. [...]" (AMORIM, 2011, p.42) e propiciava, por exemplo, “[...] uma melhor compreensão da íntima relação simbiótica entre as questões de desenvolvimento socioeconômico e a prevenção de conflitos [...]" (AMORIM, 2010). Desse modo, "essa doutrina brasileira de participação, que vincula a construção da paz à promoção do desenvolvimento, encontrou sua concretização prática na MINUSTAH” (AMORIM, 2010).

Para Paulo Esteves (2012b, p.8), a ênfase dada pela diplomacia brasileira às atividades relacionadas ao desenvolvimento, como partes constitutivas dos processos de peacebuilding e como elementos fundamentais para a prevenção de conflitos, demonstra uma convergência com as normas estabelecidas pelas Nações Unidas. A manobra do Brasil era, então, "to understand development beyond the liberal frame, trying to incorporate practices and emulate specific policies designed to combat poverty and hunger" (ESTEVES, 2012b, p.8). Essa percepção vai de encontro com o que Celso Amorim aponta serem os dois principais aspectos da política externa brasileira durante o governo Lula:

(a) on the one hand, situations that are part of the international agenda, irrespective of our will; and (b) on the other hand, our effort to reshape the international agenda - albeit in a limited way - with a view to creating a world more conducive to international cooperation for peace and development (AMORIM, 2004a, grifo nosso).

Desse modo, ao mesmo tempo em que a política externa brasileira está alinhada aos preceitos liberais da governança internacional no que concerne às práticas de peacebuilding, também parece querer resistir aos avanços desses preceitos ao imprimir uma ênfase diferente sobre a melhor forma de conduzir tais práticas, o que permite o Brasil diferenciar-se dos países do Norte. Já o que diz respeito ao problema da intervenção, a posição brasileira se apresenta um tanto quanto dúbia, uma vez que aceitou participar de uma missão baseada no Capítulo VII da Carta, e continua defendendo uma reinterpretação do conceito de segurança humana "[...] in order to exclude the use of force as a "viable" way to build peace and attain human security and, finally, to insist on UN Charter original text" (ESTEVES, 2012a, p.13), como declara Amorim: 
A segurança humana resulta, principalmente, de sociedades justas e equitativas, que promovem e protegem os direitos humanos, fortalecem a democracia e respeitam o estado de direito, ao mesmo tempo em que criam oportunidades de desenvolvimento econômico com justiça social. As Nações Unidas não foram criadas para disseminar a filosofia de que a ordem deve ser imposta pela força. Esse recurso extremo deve ser reservado a situações em que todos os demais esforços tenham sido esgotados e as soluções pacíficas sejam realmente inviáveis. E o julgamento sobre a existência dessas condições excepcionais há que ser sempre um julgamento multilateral. A Carta contempla dois tipos de situação para o uso da força: a necessidade de manter ou restaurar a paz e a segurança internacionais,e o direito de legítima defesa. Esses dois conceitos não podem ser confundidos, sob pena de embaralharmos as bases doutrinárias da Organização (BRASIL, 2005, p.70, grifos nossos).

Ou seja, o que o Amorim quer destacar é que desenvolvimento não deve estar atrelado à segurança. $\mathrm{O}$ uso da força, segundo o ex-chanceler, só deve ser utilizado quando a decisão for tomada multilateralmente, quando todos os meios pacíficos tiverem sido esgotados, e apenas com o intuito de "necessidade de manter ou restaurar a paz e a segurança internacionais, e o direito de legítima defesa" (BRASIL, 2005, p.70). No caso do Haiti, a decisão de intervenção foi tomada no âmbito multilateral, mas será que se configurava em uma ação realmente necessária? A segurança e a paz internacionais estavam em jogo? Podese dizer que a intervenção no Haiti, em 2004, foi autorizada a partir de uma abordagem de segurança humana, tal como é entendida pela ONU.

Mas, seguindo o argumento de Amorim, a diplomacia brasileira quer ressaltar o componente do desenvolvimento presente no conceito de segurança humana. O governo brasileiro acredita ter condições de contribuir de forma diferenciada no alcance de tal objetivo é essa crença que, segundo Amorim, permite o país disputar um papel de destaque na governança global. Nesse caso, a adoção do conceito de "não indiferença" possibilitou o envolvimento do Brasil no comando da missão do Haiti, que tem buscado exercer esse potencial de liderança no campo do desenvolvimento. Por isso,

nós sempre defendemos que a ação no Haiti tinha três pilares: um deles era obviamente a paz, a ordem e a segurança; outro era o diálogo político - e não apenas a preservação daquele primeiro governo, cujos componentes eram quase todos provenientes da chamada burguesia haitiana, a burguesia de Pétionville; o terceiro era a reconstrução e o desenvolvimento do Haiti (AMORIM, 2011, p.42, grifo nosso). 
Portanto, o componente militar da missão, destinado a atingir a paz, a ordem e a segurança, no Haiti, baseado no Capítulo VII, parece ter sido reconhecido por Amorim. Ademais, a participação no caso haitiano teria como consequência um fortalecimento não apenas do papel do país, mas da região sulamericana como um todo. De modo que uma lógica do Sul estaria em contraponto com uma lógica do Norte. E essa foi vista como a oportunidade de apresentar esse diferencial ao mundo, como destaca Amorim no discurso abaixo:

O Brasil vinha tendo uma projeção internacional grande e aquela era uma oportunidade. Nós percebemos que havia uma chance para uma ação de natureza diferente. Até então, na prática, as ações no Haiti haviam sido quase sempre comandadas por uma grande potência, normalmente os Estados Unidos. A França, evidentemente, esteve muito envolvida, embora de forma mais remota; o Canadá, até certo ponto também. Mas nunca um país da América Latina ou, mais especificamente, um país da América do Sul havia estado à frente. A própria dificuldade que os Estados Unidos tinham, naquele momento, de se envolver militarmente na situação criava também oportunidade para que o Brasil e outros países da América do Sul participassem da força de paz. É importante dizer que vários países da América do Sul participam da força de paz - entre eles, Peru, Chile, Uruguai, Argentina - além da Guatemala. Então, era uma oportunidade de a América do Sul e da América Latina, de forma mais ampla, terem um papel de liderança na operação (AMORIM, 2011, p.40, grifos nossos).

Mas até que ponto a postura brasileira se diferenciava daquela adotada tradicionalmente pelos países do Norte? A começar pela surpreendente concordância do governo em participar de uma missão baseada no Capítulo VII, com a justificativa de esta ser "menos intervencionista", por ter como fim último a justiça social (LIMA, 2005, p.19). Kai Kenkel (2010) destaca que o componente de similaridade cultural entre o Brasil e o Haiti e o foco brasileiro nas atividades de desenvolvimento e cooperação acabam por amenizar as ações eventuais de enforcement.

Essa ideia de graus de interferência foi posta pelo próprio Amorim, quando explicava que, no momento da primeira intervenção no Haiti, em 1994, "resistimos a uma posição que nos pareceu muito intervencionista" (AMORIM, 2011, p.244). Quer dizer, há uma reinterpretação sobre o que significa a intervenção. Se antes, qualquer ação em um Estado com o uso da força e sem o seu consentimento era percebido pela política externa brasileira como uma 
violação do princípio de não intervenção, agora, isso parece depender mais da legitimidade do que da legalidade propriamente.

Será que os fins justificam os meios? Segundo Maria Regina Soares de Lima (2005, p.19), “o contraponto ao conceito de não intervenção, pedra de toque da tradição diplomática brasileira, não poderia ser mais ilustrativo da diferença que se quer estabelecer". O caso do Haiti parecia ser uma oportunidade única para o que Amorim (2011, p.41) chamou de "uma ação de natureza diferente”. Era a chance de o país diferenciar-se em relação aos países do Norte ao enfatizar sua experiência em lidar com os problemas de combate à fome e à pobreza no plano nacional. Para isso, a expressão "não indiferença" foi utilizada como uma saída para que o Brasil mantivesse no discurso a defesa ao princípio de não intervenção, mas pudesse justificar sua participação na MINUSTAH. Esse instrumento retórico também é bastante utilizado por países do Norte, como foi o caso da intervenção no Iraque. Guardadas as devidas proporções, porque no caso do Iraque o uso da força não foi autorizado pelas Nações Unidas, o fato é que a intervenção foi considerada legítima pelos Estados Unidos porque os fins - a eliminação de bolsões de terroristas e a necessidade de implantar democracia - eram percebidos como "nobres" (LIMA, 2005, p.19).

Claro que isso não significa que não haja diferença alguma entre o comportamento dos países do Norte e do Sul, mas talvez as semelhanças sejam maiores do que se quer acreditar. Após o processo decisório para integrar a MINUSTAH, o Brasil se encontraria novamente em uma situação paradoxal. Dessa vez relacionada a sua atitude face ao impasse criado nas eleições haitianas, em 2006. A forma como foi conduzida a vitória de René Préval ao cargo de presidente revela que as ações em prol do desenvolvimento, nesse caso, pelo fortalecimento da democracia, podem ser tanto quanto, ou mais intervencionistas que as ações militares. Mesmo Celso Amorim afirmando que o Brasil não participaria "de nenhuma força que fosse atuar no sentido de modificar o quadro político do Haiti" (AMORIM, 2011, p.37), no episódio das eleições, o Brasil não só ajudou a modificar o quadro político do Haiti, como agiu de forma contrária às leis previstas por aquele país.

Diante do resultado do primeiro turno, em que nenhum candidato havia alcançado mais de $50 \%$ dos votos (Préval obteve 48,7 por cento), a condução constitucionalmente correta seria encaminhar o processo 
eleitoral para o segundo turno. Mas havia o agravante de suspeita de fraude, como explica Amorim (2011, p.37):

[...] havia uma forte e bem fundamentada suspeita de que os votos brancos computados eram excessivos. Essa impressão era reforçada pela ausência de um padrão estatístico dos votos em branco. Houve lugares em que havia 9 por cento ou 10 por cento de votos em branco. Houve mesmo urnas em que, de um total de 400 a 500 votos, 200 eram em branco. E a suspeita de fraude em prejuízo de Préval era agravada pelo fato de o voto no Haiti ser facultativo.

Em meio a tantas dúvidas, Amorim (2011, p.37) salientou que "todos concordavam que se houvesse segundo turno, Préval ganharia”. Mas essa era uma suposição, que embora seja válida, se pensada naquele contexto, não se constituía um fato. Outro elemento analisado, segundo Amorim (2011), era que a sociedade encontrava-se em estado de ebulição, o que aumentava os riscos de violência e revolta. E como Manigat (o segundo colocado com 11 por cento dos votos) se recusava a aceitar a vitória de Préval, "surgiu a ideia de que alguma forma de inferência estatística deveria ser feita" (AMORIM, 2011, p.52). Foi, então, decidido redistribuir proporcionalmente os votos brancos, ação inspirada na Constituição Belga, e que implicava proclamação de Préval como o novo presidente haitiano (AMORIM, 2011, p.52).

Renata de Melo Rosa (2007), depois de entrevistar em Porto Príncipe o candidato derrotado Leslie Manigat sobre o resultado das eleições, observou que:

Se analisarmos o ponto de vista daqueles que saíram vencidos das eleições de 2006, amargando a influência da política de relações exteriores brasileira de contagem de votos de uma maneira diferenciada com a finalidade instrumental de decretar a vitória de Préval, o Haiti ainda corre o sério risco de desestabilização civil (ROSA, 2007, p.17 apud CARVALHO; ROSA, 2011, p.499)

O governo brasileiro se defende de tais críticas dizendo que não foi o Brasil que propôs tal fórmula (AMORIM, 2011, p.52) e que "a solução foi compartilhada por várias organizações e países [...], e plenamente incorporada pelas instituições haitianas [...], sendo aprovada pelo Conselho Eleitoral Provisório" (AMORIM, 2011, p.52). Além disso, para Amorim (2011, p.55), o Brasil estava cumprindo com seu objetivo de contribuir para que houvesse um diálogo político intenso, "mas temos que fazer isso de maneira sutil e não impositiva. Esse é o grande desafio para a comunidade internacional. E é um 
papel que países como o Brasil podem desempenhar e que países que estão acostumados a agir com mão pesada não conseguem fazer". Mesmo com todas as justificativas apresentadas por Amorim, que são bastante plausíveis, o fato é que houve uma interferência nada sutil na política interna do Haiti.

A decisão de assumir a liderança militar da MINUSTAH provocou alguns questionamentos no interior da comunidade política externa brasileira, e inclusive, na mídia e em setores da sociedade civil, sobre as consequências de médio e longo prazo de o país se responsabilizar por tal tarefa. "As dificuldades de manter a efetividade da missão, os riscos encontrados no uso da força para manter a ordem no Haiti e a justificação para tal política diante da gravidade dos problemas sociais domésticos" (LIMA; HIRST, 2009, p.71) são alguns dos pontos que merecem ser destacados.

Com a moeda estabilizada desde 1994, o Brasil, segundo a empresa de consultoria e pesquisa Economist Intelligence Unit (EIU), ${ }^{\mathbf{3 0}}$ se tornou em 2011, a sexta maior economia do mundo. Ou seja, o sexto maior produto interno bruto (PIB) medido em dólares à taxa de câmbio corrente no período (COSTA, 2011). Mesmo que a crise econômica na Europa tenha contribuído para subida no ranking, e que o PIB per capita ainda esteja abaixo do esperado, o fato é que o peso da economia brasileira no globo não pode ser ignorado. Especialmente na América do Sul, sob qualquer indicador econômico, o Brasil pode ser definido como "potência regional", uma vez que quase metade do PIB da região é de origem brasileira (LIMA; HIRST, 2009, p.71). Ademais, o Brasil tem uma estrutura do comércio exterior mais diversificada do que a maioria de seus vizinhos - menos da metade das exportações brasileiras são destinadas à região (LIMA; HIRST, 2009, p.71; ALMEIDA, 2011).

Pode-se também afirmar que a democracia está consolidada no país e as instituições políticas permanecem estáveis. Desde o fim do regime militar não se verificou qualquer tentativa extrainstitucional de interromper o processo democrático (LIMA; HIRST, 2009, pp.71-72). Contudo, apesar do bom desempenho político e econômico do país, e a afirmação do Brasil como uma "potência média", a desigualdade social ainda é o principal problema no plano doméstico. Deste quadro, derivam altos índices de violência urbana e um enorme

\footnotetext{
${ }^{30}$ Ligada à revista The Economist.
} 
contraste social. Nesse sentido, comparativamente, "a assimetria econômica entre o Brasil e outros países sul-americanos é praticamente revertida quando levamos em consideração o desempenho social do país" (LIMA; HIRST, 2009, pp.71 e 72). Segundo o Relatório de Desenvolvimento Humano (RDH, 2011, p.128), produzido pelo PNUD, O IDH brasileiro de 2011 é de 0,718 ( $84^{\text {a }}$ posição dentre 187 países), na escala que vai de 0 a 1 , sendo, como tem aparecido nos últimos anos, inferior à média da Argentina $(0,797)$, Chile $(0,805)$, Uruguai $(0,783)$, México $(0,770)$, Peru $(0,725)$ e Venezuela $(0,735)$, por exemplo.

Mesmo com um avanço do país no ranking de IDH nos últimos dez anos (RDH 2011, p.132), o Brasil permanece como um dos países mais desiguais do mundo. De acordo com o coeficiente de $\mathrm{Gini}^{31}$ - que mede a desigualdade a partir da distribuição de renda, no RDH de 2005 (p.56 e 271), referente à pesquisa realizada em 2001, o Brasil ocupava a oitava posição no ranking geral, com o índice de 59,3, na frente apenas da Guatemala $(59,9)$, Suazilândia $(60,9)$, República Centro-Africana (61,3), Serra Leoa $(62,9)$, Botsuana $(63,0)$, Lesoto $(63,2)$ e Namíbia $(70,7)^{32}$. O documento mostrava que enquanto os $10 \%$ mais ricos da população se apropriavam de $46,9 \%$ da renda nacional, os $10 \%$ mais pobres recebiam apenas 0,7\%. No Relatório de 2011 (p.136), apesar de pequena melhora, o Brasil ainda aparece com o baixo índice de 53,9, estando entre os 12 países mais desiguais do mundo.

A discrepância entre o desempenho econômico e político, por um lado, e o desempenho social de outro, é uma das características comuns entre as potências emergentes, e não parece afetar a imagem brasileira como um país em ascensão. Por outro lado, se o país quer exercer liderança justamente no campo do desenvolvimento, precisa mostrar credibilidade. Uma das formas é realizar mudanças significativas nos índices de desigualdade social.

Há pouco tempo saiu uma matéria no jornal New York Times acusando soldados brasileiros de terem espancado até a morte três jovens haitianos.

31 Criado pelo italiano Corrado Gini, mede a concentração de renda de um país e indica desigualdade maior à medida que se aproxima de 100. Ou seja, hipoteticamente, zero significaria que todos os indivíduos teriam a mesma renda e 100 mostraria que apenas um indivíduo teria toda a renda de uma sociedade. Cf. em: $<$ http://www1.folha.uol.com.br/folha/cotidiano/ult95u112798.shtml $>$. Acesso em 20 de fevereiro de 2012.

${ }^{32}$ Cf.: <http://www.bbc.co.uk/portuguese/reporterbbc/story/2005/09/050907_idhrw.shtml>. Acesso em: 20 de fevereiro de 2012. 
The United Nations said Friday that it was investigating allegations of assault and attempted homicide by peacekeepers in Haiti. Local media have reported that a group of Brazilian peacekeepers working for the United Nations mission in Haiti severely beat and left for dead three young Haitian men earlier this week $^{33}$ (grifos nossos).

Isso mostra que o dia a dia da missão é muito mais complexo do que parece. E chama a atenção para a necessidade de um melhor preparo dos soldados brasileiros. Vale ressaltar que isso não é um problema exclusivo do Brasil. É só lembrar as fotos e vídeos divulgados de soldados americanos torturando presos iraquianos. Mas a questão é que se o Brasil quer imprimir uma marca diferenciada, quer propor uma nova abordagem para as operações de paz, este tipo de notícia cria uma sensação de descrédito.

No plano doméstico, a participação do exército em ações de segurança, principalmente no Rio de Janeiro sob o título de Força de Pacificação, também tem sido controversa entre os moradores dessas comunidades. No último dia 9 de março, militares do exército, que desde dezembro de 2010 ocupam os complexos da Penha e do Alemão, no Rio de Janeiro, foram acusados de torturar um estudante. $^{34}$

Além disso, o uso da força tem sido constante na MINUSTAH. O contingente inicial contava com 1.200 tropas aproximadamente e este número quase dobrou após o terremoto de janeiro de 2011. Kai Kenkel destaca que o comandante da Força Militar tem sido sempre um general brasileiro, que exercita o comando sobre tropas que são, em grande parte, provenientes de países da América Latina, diferente de outras operações de paz, em que o comando varia de nacionalidade. $\mathrm{O}$ autor ressalta que, em parte, a aceitação do uso de altos níveis de força é facilitado pelo fato de que isto está integrado em um esforço muito mais amplo de desenvolvimento e um significativo esforço com a cooperação Sul-Sul (KENKEL, 2010).

\footnotetext{
33 Disponível em: <http://www.nytimes.com/2011/12/17/world/americas/haiti-un-investigatesmedia-reports-of-attacks-by-brazilianpeacekeepers.html?ref=departmentofpeacekeepingoperations >; $<$ http://topics.nytimes.com/topics/reference/timestopics/organizations/u/united_nations/de partment_of_peacekeeping_operations/index.html>. Acesso em: 10 de março de 2012.

34 Disponível em: <http://extra.globo.com/casos-de-policia/jovem-torturado-na-vila-cruzeiro-dizter-sido-intimidado-por-militares-da-forca-de-pacificacao-4308527.html> Acesso em: 15 de março de 2012.
} 
Segundo Kenkel (2010), a atuação brasileira no Haiti é marcada por dois elementos principais: a ênfase no desenvolvimento integrado desde o início da missão e uma abordagem mais próxima da população baseada também na afinidade cultural. Para o autor, esses dois elementos constituem - ao mesmo tempo - vantagens e desvantagens para o Brasil. Ele destaca que as tropas brasileiras estão mais acostumadas a trabalharem em contextos de subdesenvolvimento bastante similares com o encontrado no Haiti, uma vez que possuem experiência em projetos domésticos desse tipo. Uma "forma de interação próxima e calorosa” (KENKEL, 2010, pp. 656-658). A vantagem é que há uma melhor adaptação no país, o que aumenta a efetividade da ação e a aceitação da população local. O autor lembra que os esforços bilaterais de cooperação e as parcerias com ONGs brasileiras, como a Viva Rio, foram positivos.

A diplomata Gilda Motta ressalta o diferencial da abordagem brasileira, baseada nos traços culturais de tolerância e adaptabilidade:

A "vocação construtiva" brasileira também se exerce no terreno, onde o País é particularmente bem recebido em função da ausência de agenda econômica ou política determinante de condicionalidades em sua atuação e em razão de traços culturais de tolerância e adaptabilidade - além de, impossível ignorar, o extraordinário fascínio exercido pelo futebol brasileiro nos países em desenvolvimento em que o esporte é praticado (em particular, África e América Central) (NEVES, 2009, p. 197, grifos nossos).

Gilda Motta também acrescenta que o futebol pode ser uma via interessante de contato, com grande potencial de cooperação:

O esporte é uma área em que, em que pesem algumas iniciativas, o Brasil ainda não aproveita plenamente o potencial de cooperação, sobretudo em países africanos em estado de reconstrução pós-conflito. O futebol tem excelente potencial na composição de programas de reconciliação e inclusão social, de ocupação dos jovens e reintegração de ex-combatentes. Projeto para criação de escolinha de futebol na Libéria, onde o desemprego alcançava $85 \%$ da população, foi apresentado à Missão em Nova York e encaminhado à SERE em junho de 2005, mas a dificuldade em interagir com autoridades de país institucionalmente falido e sem Embaixada residente, e indefinições na divisão de atribuições entre a ABC e a DCE inviabilizaram reação brasileira (NEVES, 2009, p. 197, grifo nosso).

Ao mesmo tempo, a desvantagem é que as tropas brasileiras estão tendo, pela primeira vez, a oportunidade de participar de uma missão robusta deste tipo, 
e, por isso, ela ainda não foi testada em outros tipos de realidade. Segundo Kai Kenkel (2010), para que a proposta brasileira de uma nova abordagem nas operações de paz possa ser aplicada em outros contextos, é preciso um maior preparo dos soldados e uma sistematização das orientações de conduta para que sejam adaptáveis a diferentes realidades. Por enquanto, parece "existirem limites da sua exportabilidade a outros contextos de peacebulding" (KENKEL, 2010, p.657). Se o país se limitar a enviar tropas para esta categoria de Estado, a abordagem pode reter sua efetividade.

Pode-se concluir da análise dos dois casos de intervenção no Haiti (em 1994 e 2004), uma postura diferenciada da política externa brasileira. No primeiro caso, o governo de Itamar Franco não apoiou a operação coercitiva baseado nos preceitos da não intervenção. No segundo caso, durante o governo Lula, a adoção da expressão de "não indiferença" assinalou uma mudança na posição brasileira, permitindo que o país aceitasse "a certain degree of coercion and to interpret reconciliation and development in its own terms" (ESTEVES, 2012a, p.14). Desse modo, a presença brasileira no comando da MINUSTAH cria a possibilidade do país diferenciar-se em relação aos países do Norte ao enfatizar sua experiência em lidar com os problemas de combate à fome e à pobreza. $\mathrm{O}$ incentivo ao diálogo, o uso mínimo da força e a ênfase nas atividades de desenvolvimento são as marcas da condução brasileira da MINUSTAH, apesar das dificuldades e da necessidade de tornar essa conduta um processo sistematizado e adaptável para outras realidades.

\section{O Brasil e a Responsabilidade de Proteger (R2P)}

O governo brasileiro, de início, entendeu a "responsabilidade de proteger" como um direito de ingerência "sob nova roupagem" (BRASIL, 2003, p.235), segundo afirmou Celso Amorim. A tentativa de institucionalizar o conceito era entendida como uma abertura de possibilidade para ações unilaterais das grandes potências. Ademais, Amorim (BRASIL, 2003) salientou sobre a importância do respeito ao uso da força como último recurso, ressaltando a primazia do Estado em atender aos seus deveres de soberania. Significativo dizer, porém, que esses pontos já se encontram de forma explícita no relatório da ICISS, como foi visto no 
capítulo anterior e como será abordado adiante, e posteriormente no Documento da Cúpula de 2005 (Outcome Document).

A seção do relatório mais questionável é a que se refere à questão de quem decide se deve ou não haver intervenção. Conquanto a autoridade do Conselho de Segurança das Nações Unidas não seja diretamente questionada, são examinados diferentes cursos de ação - mais ou menos heterodoxos - nos casos em que o órgão permanecer paralisado em função da ameaça de veto de um de seus membros permanentes [...] Deixa-se, assim, a porta aberta a que alguns países se arroguem o direito de intervir, sem autorização expressa do Conselho de Segurança ou acompanhamento por instância verdadeiramente multilateral (BRASIL, 2003, p.236).

De maneira gradual, o governo brasileiro tem tentado se engajar mais com o debate da R2P - mas como um caminho para confirmar algumas posições já previamente desenvolvidas. Este é o caso da defesa já conhecida por uma abordagem do desenvolvimento a partir de uma ótica mais social e menos securitária; pela preferência dos usos pacíficos e diplomáticos em detrimento da força; e pelo estabelecimento de critérios mais claros que definam quando realmente se trata de uma ameaça internacional. Também é nessa direção que o Brasil briga por uma reforma no Conselho de Segurança, para que este seja um espaço mais representativo e legítimo para tomar decisões, como a aplicação do Capítulo VII.

Amorim, na abertura do Debate Geral da $60^{\mathrm{a}}$ Sessão da Assembleia Geral, em 2005, declarou que os conceitos de "segurança humana" e "responsabilidade de proteger" devem ter um lugar adequado no sistema, mas que, contudo, é uma ilusão acreditar que "podemos combater os desvios políticos que estão na origem de violações graves de direitos humanos por meios exclusivamente militares, ou mesmo por sanções econômicas, em prejuízo da diplomacia e da persuasão" (BRASIL, 2005, p.70). Segundo Amorim, o uso da força só pode ser utilizado em casos extremos, quando todos os outros recursos tiverem sido esgotados:

A segurança humana resulta, principalmente, de sociedades justas e equitativas, que promovem e protegem os direitos humanos, fortalecem a democracia e respeitam o estado de direito, ao mesmo tempo em que criam oportunidades de desenvolvimento econômico com justiça social. As Nações Unidas não foram criadas para disseminar a filosofia de que a ordem deve ser imposta pela força. Esse recurso extremo deve ser reservado a situações em que todos os demais esforços tenham sido esgotados e as soluções pacíficas sejam realmente inviáveis. E o julgamento sobre a existência dessas condições excepcionais há que ser sempre um julgamento multilateral. A Carta contempla 
dois tipos de situação para o uso da força: a necessidade de manter ou restaurar a paz e a segurança internacionais, e o direito de legítima defesa. Esses dois conceitos não podem ser confundidos, sob pena de embaralharmos as bases doutrinárias da Organização (BRASIL, 2005, p.70).

De fato, as reivindicações brasileiras provocaram impacto. A criação da Comissão de Consolidação da Paz é um bom exemplo para mostrar como a atuação do Brasil em defesa das atividades de desenvolvimento pode influenciar a criação de propostas inovadoras dentro da ONU. Dessa forma, o Brasil se aproxima cada vez mais da R2P através do componente de prevenção. Ao mesmo tempo, o problema do uso da força tem sido tratado de forma indireta pelo governo brasileiro, sempre tentando não colocar o país em uma situação comprometedora: nem se condena totalmente o uso da força, já que o Brasil lidera uma força de paz autorizada pelo Capítulo VII, nem se aprova, em face da longa tradição de defesa do princípio da não intervenção. O discurso da diplomacia brasileira tem se caracterizado ambíguo e, em alguns casos, evasivo (KENKEL, 2012a), como se pode observar na citação abaixo:

In our view, the General Assembly could examine in detail the new concept of a "collective responsibility to protect" [...] Brazil has a historic and sound commitment to human rights, democracy and the rule of law. We are parties to all main human rights machinery. It is in this context that we welcome the proposals contained in the report of the SG towards the strengthening of the system. We believe that the debate on this issue is also necessary and positive and we intend to actively participate in this exercise (BRASIL, 2005b).

Essa pode ser uma forma interessante de construir espaços para uma atuação flexível. Pois, talvez, seja justamente essa atitude que permita o Brasil buscar uma identidade de conciliador ou mediador entre os países. Por outro lado, conforme ressaltou Kai Kenkel $(2008 ; 2010 ; 2012 a)$, essa atitude também pode ser vista como uma forma de não assumir as responsabilidades que cabem a uma potência média. E se essa segunda visão prevalecer, o país terá que repensar suas estratégias de engajamento com a R2P.

A partir da palestra de Ban-Ki-Moon, de 15 de julho de 2008, quando o Secretário apresentou os três pilares da R2P e uma abordagem "estreita, mas profunda”, a Representante Permanente, Maria Luiza Ribeiro Viotti, situou o Brasil como um apoiador do segundo pilar, referente aos aspectos de prevenção, 
que são orientados pelo desenvolvimento. A Representante sublinha a atenção do Brasil às raízes do conflito como um problema prioritário para a construção de uma paz durável.

The first step towards a durable solution to humanitarian crises is to identify their root cases, which usually include underdevelopment, poverty, social exclusion and discrimination. Therefore, in addressing the responsibility to protect, we should deal first and foremost with cooperation for development and try to devise ways to reduce the disparities of all sorts that exist within nations, and among nations and regions (BRASIL, 2010a, grifos nossos).

Viotti também destaca que o terceiro pilar, sobre a "responsabilidade de reagir", é subsidiário ao primeiro pilar, referente à primazia da soberania dos Estados, e que o uso da força militar deve ser uma exceção e não uma regra.

The responsibility to protect the population from genocide, war crimes, ethnic cleansing and crimes against humanity is first and foremost an obligation of the State. Only if and when a State manifestly fails to fulfill such obligation may the international community take collective action in accordance with the Charter. In other words, the third pillar is subsidiary to the first one and a truly exceptional course of action, or a measure of last resort (BRASIL, 2010a, grifos nossos).

Em outro momento da declaração, Viotti demonstra explicitamente a postura brasileira de maior engajamento com a R2P, dizendo que esse conceito é um chamado político aos Estados para que cumpram com as suas obrigações, como determina a Carta. Afinal, segundo Viotti, a comunidade internacional já possui meios legais para deter tragédias como ocorreu em Ruanda - e que os Estados devem ter a responsabilidade de reagir a tais eventos. Neste ponto, a Representante parece sugerir que o Brasil estaria disposto a agir como determina o Capítulo VII, em casos excepcionais e de grande urgência, como em Ruanda. Talvez deixando uma brecha para justificar a atuação brasileira no Haiti e/ou futuras atuações.

In Brazil's view, it is not a principle proper, much less a novel legal prescription. Rather, it is a powerful political call for all States to abide by legal obligations already set forth in the Charter, in relevant human rights conventions and international humanitarian law and other instruments. As importantly, it is a reminder to the international community that it already has the instruments needed to act, namely those mentioned in paragraph 139 of the Outcome Document. The implications of such understanding of the responsibility to protect are far from academic: perpetrators of the four crimes referred to in the document 
cannot argue in their defense that the responsibility to protect is still to be implemented nor can the international community justify inaction with the lack of legal instruments. The tragedy in Rwanda, for example, took place neither because authorities were unaware of their legal obligation to protect their populations nor because the international community did not have the means to stop them. This is a sad truth, but we must be true to ourselves if we are serious about the responsibility to protect (BRASIL, 2010a, grifos nossos).

E, por fim, Viotti apresenta o conceito de "não indiferença" como uma forma de enfatizar a responsabilidade da comunidade internacional em lidar com as crises humanitárias, principalmente no que concerne ao combate das raízes dos conflitos, como a fome e a pobreza, mas não somente. Vale observar que a Representante não restringe a forma como essa responsabilidade deve ser exercida. Ela prioriza a cooperação, mas parece deixar em aberto a possibilidade dessa responsabilidade ter que ser exercida de outra forma, inclusive de acordo com o Capítulo VII.

\begin{abstract}
Brazil advocates the concept of "non-indifference" as a way of emphasizing the responsibility of the international community when faced with humanitarian disasters and crises, including those resulting from hunger, poverty and epidemics. These are humanitarian catastrophes that can be prevented or mitigated through political will and short, medium and long-term cooperation. This requires that developed States fulfill their development-related obligations, as agreed in Monterrey and in the Doha review conferences. "Nonindifference" also calls for enhanced South-South cooperation and innovative financing mechanisms, which complement traditional sources of financing for development. Brazil seeks to implement this approach in its South-South activities (BRASIL, 2010a, grifos nossos).
\end{abstract}

\title{
A proposta brasileira: Responsabilidade ao Proteger (RWP)
}

A noção de "responsabilidade ao proteger",35 foi mencionada pela primeira vez pela Presidenta Dilma Rousseff em seu discurso de abertura da Assembleia Geral da ONU, em setembro de 2011. Em seguida, o Brasil divulgou nota conceitual que discute a noção de que a responsabilidade de proteger deve ser exercida pela comunidade internacional com um alto nível de responsabilidade ao proteger. No dia 21 de fevereiro deste ano, o atual Ministro das Relações

35 "Responsibility while protecting" (RWP), em inglês. 
Exteriores, Antonio de Aguiar Patriota, fez um pronunciamento sobre a ideia de Responsabilidade ao Proteger na ONU (BRASIL, 2012).

No início do discurso, Patriota reconhece que o Documento Final da Cúpula Mundial de 2005, que conseguiu um consenso acerca da Responsabilidade de Proteger, também afirma "claramente que essa responsabilidade deve ser exercida, em primeiro lugar, por meio do uso de meios diplomáticos, humanitários e outros meios pacíficos, e que apenas nos casos em que os meios pacíficos se revelam inadequados deveriam ser cogitadas medidas coercitivas" (BRASIL, 2012). Como foi assinalado no segundo capítulo, Patriota destaca a diferença entre "responsabilidade coletiva - que pode ser plenamente exercida através de medidas não coercitivas - e segurança coletiva - que envolve uma avaliação política caso a caso por parte do Conselho de Segurança” (BRASIL, 2012).

Pretende-se, assim, dar um novo sentido ao significado de responsabilidade - que deve estar associado ao combate das raízes dos conflitos e não ao uso da força. Mesmo que esta esteja relacionada com a proteção de civis. $\mathrm{O}$ foco que Patriota quer colocar é diferente, embora haja o reconhecimento da necessidade, em casos excepcionais, de uma intervenção militar. Mas também não fica claro se o Brasil apoiará tais casos. O diplomata insiste que esse não pode ser o objetivo primeiro da comunidade internacional, pois a proteção de civis durante um conflito é um problema pontual, enquanto o subdesenvolvimento é um problema contínuo - e gerador de várias formas de violência e inseguranças.

Patriota ressalta que é preciso haver critérios rigorosos sobre a real necessidade de uma intervenção militar, pois "o uso da força sempre traz consigo o risco de causar mortes involuntárias e de disseminar violência e instabilidade" (BRASIL, 2012). E o diplomata completa que "o fato de que ela seja utilizada com o objetivo de proteger civis não faz das vítimas colaterais ou da desestabilização involuntária eventos menos trágicos" (BRASIL, 2012). Responsabilidade é entendida como a obrigação da comunidade internacional em ter todos os cuidados possíveis e imagináveis em operações que utilizem o uso da força. Em especial, o Conselho de Segurança tem que ser responsável por "conscientizar-nos dos perigos envolvidos em sua utilização e de criar mecanismos que possam fornecer uma avaliação objetiva e detalhada de tais perigos, bem como formas e meios de evitar danos aos civis" (BRASIL, 2012). 
A partir do discurso da Presidente Dilma, o Ministro lembra que intervenções humanitárias passadas têm causado consequências contrárias ao objetivo inicial: agravamento dos conflitos existentes, disseminação do terrorismo, dando "origem a novos ciclos de violência e [aumentando] a vulnerabilidade das populações civis” (BRASIL, 2012). É com base nesses argumentos que o governo brasileiro atual entende ser necessário "dar um passo conceitual adicional para lidar com a responsabilidade de proteger [...]" (BRASIL, 2012). Este seria o núcleo da ideia de uma "responsabilidade ao proteger", que segundo Patriota, deve evoluir juntamente com o conceito de "responsabilidade de proteger", "com base em um conjunto acordado de princípios fundamentais, parâmetros e procedimentos" (BRASIL, 2012).

Não faz sentido, porém, que seja necessário um esforço para conciliar princípios, parâmetros e procedimentos das duas ideias. Todos os destaques dados pelo Ministro já estão claramente expostos no relatório da ICISS. Nesse aspecto, a proposta brasileira não parece ter nada de essencialmente novo - o que parece ter sido reconhecido pelo Ministro em vários momentos do pronunciamento. Por outro lado, também parece ser evidente que muito do que está escrito no Relatório da ICISS não está sendo cumprido.

A recente intervenção humanitária na Líbia, considerada "the first unambiguous military enforcement of the Responsibility to Protect norm" (PATRICK , 2011) é um ótimo exemplo, como alertou o título de uma matéria publicada no "The Guardian": "If the Libyan war was about saving lives, it was a catastrophic failure: Nato claimed it would protect civilians in Libya, but delivered far more killing” (MILNE, 2011). Uma série de evidências mostra que cerca de 500 pessoas, entre civis e combatentes, foram mortos em apenas 10 dias com os bombardeios da OTAN. Ainda segundo o jornal, "that has followed a two month-long siege and indiscriminate bombardment of a city of 100,000 which has been reduced to a Grozny-like state of destruction by newly triumphant rebel troops with Nato air and special-forces support" (MILNE, 2011).

Além disso, a matéria evidencia os perigos de se tomar partido de uma disputa política. Grupos políticos contra o regime de Gaddafi cometeram crimes e atrocidades da mesma forma que o próprio regime. Assim, fica a pergunta sobre a imparcialidade desse tipo de ação. Deve-se pensar se o uso ostensivo da força não acaba incitando ainda mais violência. Se a intenção é exclusivamente proteger 
civis, é preciso refletir cuidadosamente sobre as estratégias que serão utilizadas para que, no fim, não se acabe chegando ao resultado oposto.

Amnesty International has now produced compendious evidence of mass abduction and detention, beating and routine torture, killings and atrocities by the rebel militias Britain, France and the US have backed for the last eight months - supposedly to stop exactly those kind of crimes being committed by the Gaddafi regime (MILNE, 2011, grifos nossos).

O Ministro Antonio Patriota alertava justamente para o papel dos soldados em uma intervenção humanitária: em prol de um "bem maior", a violência é acobertada, induzida, e, muitas vezes, produzida pelas próprias tropas que deveriam evitá-la. A própria escolha de ataques aéreos para proteção de civis é um ponto levantado pelo Brasil, da mesma forma que à época de Kosovo.

Por isso, a proposta brasileira se mostra bastante interessante por destacar que as ideias centrais da R2P, aprovada pela Assembleia, em 2005, precisam ser levadas mais a sério. Em outras palavras, a iniciativa brasileira pode ser interpretada como um pedido de orientações mais claras para salvaguardar princípios como o da primazia da responsabilidade do Estado, do uso da força como último recurso e o da proporcionalidade. Para fazer com que tais princípios sejam, de fato, seguidos na prática. As preocupações a que se refere a “responsabilidade ao proteger" estão na ordem do dia. É realmente essencial pensar sobre como direcionar esse esforço para ações viáveis. Este parece ser o maior desafio.

Analisemos os pontos ressaltados no pronunciamento juntamente com os elementos destacados no relatório da ICISS. Em primeiro lugar, o Ministro ressalta que "não causar danos - [...] deve ser o lema daqueles que são obrigados a proteger os civis" (BRASIL, 2012). Esse aspecto é abordado no Relatório como um dos princípios de precaução:

Reasonable prospects: There must be a reasonable chance of success in halting or averting the suffering which has justified the intervention, with the consequences of action not likely to be worse than the consequences of inaction (ICISS, 2001, p.XII, grifos nossos). 
O segundo ponto enfatizado pelo Ministro está relacionado com o aspecto da prevenção. Patriota destaca que "é a ênfase na diplomacia preventiva que reduz o risco de conflito armado e os custos humanos a ele associados" (BRASIL, 2012). De fato, essa questão é um dos cernes da R2P:

\section{Prevention is the single most important dimension of the responsibility to protect:}

prevention options should always be exhausted before intervention is contemplated, and more commitment and resources must be devoted to it (ICISS, 2001, p. XI, grifo nosso).

The basic point of preventive efforts is of course to reduce, and hopefully eliminate, the need for intervention altogether. But even where they have not succeeded in preventing conflict or catastrophe, they are a necessary precondition for responding effectively to it (ICISS, 2001, p. 19)

O terceiro elemento levantado no pronunciamento é a necessidade de maior rigor por parte da comunidade internacional "em seus esforços para exaurir todos os meios pacíficos disponíveis nos casos de proteção de civis sob ameaça de violência, em consonância com os princípios e propósitos da Carta das Nações Unidas [...]" (BRASIL, 2012). Da mesma forma, essa preocupação está clara no Relatório:

Last resort: Military intervention can only be justified when every non-military option for the prevention or peaceful resolution of the crisis has been explored, with reasonable grounds for believing lesser measures would not have succeeded (ICISS, 2001, p. XII).

$\mathrm{O}$ quarto e o quinto procedimentos entendidos como fundamentais para Patriota é a utilização da força de maneira a "produzir o mínimo possível de violência e de instabilidade. Sob nenhuma circunstância podem-se gerar mais danos do que se autorizou evitar" (BRASIL, 2012). O Ministro salienta que "no caso de o uso da força ser contemplado, a ação deve ser criteriosa, proporcional e limitada aos objetivos estabelecidos pelo Conselho de Segurança" (BRASIL, 2012). Isso é abordado a partir do princípio de proporcionalidade, como descrito abaixo: 
Proportional means: The scale, duration and intensity of the planned military intervention should be the minimum necessary to secure the defined human protection objective (ICISS, 2001, p. XII).

E, por último, o Ministro destaca a necessidade de se aprimorar os procedimentos existentes no Conselho para monitoramento e avaliação "da maneira como as resoluções são interpretadas e aplicadas, para assegurar a responsabilidade ao proteger" (BRASIL, 2012). O Relatório demonstra particular preocupação com a operacionalização do conceito, como está representado pelos dois itens abaixo:

2.2 (...) If intervention for human protection purposes is to be accepted, including the possibility of military action, it remains imperative that the international community develop consistent, credible and enforceable standards to guide state and intergovernmental practice.

2.3 Any new approach to intervention on human protection grounds needs to meet at least four basic objectives:

- to establish clearer rules, procedures and criteria for determining whether, when and how to intervene;

- to establish the legitimacy of military intervention when necessary and after all other approaches have failed;

- to ensure that military intervention, when it occurs, is carried out only for the purposes proposed, is effective, and is undertaken with proper concern to minimize the human costs and institutional damage that will result;

- and to help eliminate, where possible, the causes of conflict while enhancing the prospects for durable and sustainable peace (ICISS, 2001, p. 11).

Patriota expõe a atual postura brasileira sobre o tema da intervenção, declarando que "o estabelecimento desses procedimentos não deve ser entendido como meio de impedir, ou atrasar indevidamente, a autorização de ações militares nas situações estabelecidas pelo Documento Final da Cúpula Mundial de 2005" (BRASIL, 2012). Ou seja, há o reconhecimento explícito na necessidade do uso da força em casos excepcionais, o que demonstra uma maior flexibilização do país em relação a este tema - apesar das tentativas de não fazer parecer assim. Em seguida, o Ministro imprime a crítica brasileira, salientando que o emprego do uso da força tem que ser responsável e legítimo. 
A ideia de "responsabilidade ao proteger" problematiza a aplicação das intervenções humanitárias. Um dos méritos da iniciativa brasileira é trazer de volta para o debate questões antigas que ainda hoje não são plenamente respeitadas. A elaboração de mecanismos dentro do Conselho que permitam o monitoramento e a avaliação da maneira como as resoluções são interpretadas e aplicadas parece ser uma urgência. $\mathrm{O}$ apelo do Ministro sobre a necessidade de "assegurar a prestação de contas daqueles autorizados a fazer uso da força" (BRASIL, 2012) induz a pensar também na possibilidade de criação de instrumentos de punição para interventores que não cumpram com os princípios expostos no Relatório da ICISS. Essa seria uma forma de evitar a impunidade e recorrências futuras (STUENKEL, 2011).

Portanto, a "responsabilidade ao proteger" abre um caminho para se pensar em alternativas. Mas é essencial que se crie projetos viáveis. Para o Brasil, esta pode ser uma oportunidade importante de exercer liderança no plano internacional. Por isso, o governo não deve deixar, sobretudo, que este esforço se limite ao debate desta ideia, mesmo que isso já seja uma ação significativa. É fundamental que se pense em mecanismos que transformem a proposta brasileira em uma pressão para os países do Norte, e que isso se reflita na operacionalização das intervenções. Ademais, a iniciativa da Presidente Dilma Rousseff, se orquestrada com outros países, pode se tornar mais uma pressão pela reforma do Conselho de Segurança.

Essa pode ser uma chance de o Brasil alterar a percepção predominante de que o país não é central para a produção de normas internacionais, segundo a visão de países ocidentais, especialmente os Estados Unidos (HERZ, 2011, p.29). A recepção nada calorosa da nova proposta brasileira pela maioria dos países do Norte demonstra que esta percepção ainda é muito forte. O resultado é que qualquer tentativa de proposição de normas pelos países do Sul é rapidamente desqualificada. A partir de uma participação ativa na proposição de regras na governança liberal, o Brasil busca transformá-las, visando, um dia, fazer parte do seu núcleo. 


\section{- Brasil e a Comissão para Consolidação da Paz (Peacebuilding Commission)}

A iniciativa de se criar uma Comissão para Consolidação da Paz (ou PBC, em inglês) fazia parte de um longo processo de reforma da Organização, iniciado desde o fim da Guerra Fria, conforme analisado no primeiro capítulo. Nesse contexto, a Comissão pode ser vista como um resultado do esforço de construção de um nexo discursivo entre segurança e desenvolvimento ao longo de todo esse período. Mas, sem dúvida, a invasão do Iraque pelos Estados Unidos, em 2003, sem a aprovação do Conselho de Segurança da ONU (CSNU), e sob a campanha da "guerra contra o terrorismo", deu um novo impulso para se repensar o papel e a atuação da Organização (NEVES, 2009, p.89).

Além da abalada credibilidade do CSNU, havia o fato de que o terrorismo precisava ser combatido. As atividades de prevenção de conflito poderiam ser um avanço. Kofi Annan - o então Secretário-Geral - aproveitou o momento de crise da Organização para nomear, em 2004, o Painel de Alto Nível sobre "Ameaças, Desafios e Mudança”. A partir das recomendações do Painel, Annan publicou o relatório "Liberdade Mais Ampla", em 2005. Uma das propostas do Painel era de que fosse criada uma Comissão para Consolidação da Paz (ONU, 2004b, §261269 e recomendações 82-85 do Anexo I do mesmo documento) - ideia que também foi apresentada no relatório de Annan no capítulo sobre a consolidação da paz (ONU, 2005a, §114 a 119). O Secretário-Geral diante daquele momento difícil assumiu falhas e afirmou que era preciso adotar novas estratégias para que os esforços voltados à prevenção de conflitos pudessem ser mais eficazes, como é possível conferir abaixo:

Our record of success in mediating and implementing peace agreements is sadly blemished by some devastating failures. Indeed, several of the most violent and tragic episodes of the 1990s occurred after the negotiation of peace agreements - for instance in Angola in 1993 and in Rwanda in 1994. Roughly half of all countries that emerge from war lapse back into violence within five years. These two points drive home the message: if we are going to prevent conflict we must ensure that peace agreements are implemented in a sustained and sustainable manner (ONU, 2005a, § 114 apud NEVES, 2009, p.111).

Como analisou o Painel de Alto Nível sobre "Ameaças, Desafios e Mudança", havia um vazio institucional: "there is no place in the United Nations 
system explicitly designed to avoid State collapse and the slide to war or to assist countries in their transition from war to peace" (ONU, 2004b, §261 apud NEVES, 2009, pp.111-112). Em seu relatório, Kofi Annan confirmou este parecer:

[...] at this very point there is a gaping hole in the United Nations institutional machinery: no part of the United Nations system effectively addresses the challenge of helping countries with the transition from war to lasting peace. I therefore propose to Member States that they create an intergovernmental Peacebuilding Commission, as well as a Peacebuilding Support Office within the United Nations Secretariat, to achieve this end (ONU, 2005a, § 115, grifo nosso apud NEVES, 2009, p.112).

Portanto, "a arquitetura institucional da ONU carecia [...] de órgão que se incumbisse de criar as condições mínimas necessárias não apenas ao alcance da paz, mas de certa qualidade de paz que se sustentasse no tempo" (NEVES, 2009, p.112). O Órgão teria como uma das funções coordenar as diversas agências e programas da ONU que integram as missões de peacebuilding - o que ainda constitui uma das principais dificuldades das operações multidimensionais. Além disso, o Órgão também seria um espaço em comum onde todos os envolvidos nas atividades de reconstrução (ONU, doadores, tropas, atores e organizações regionais, instituições financeiras e o governo nacional e transitório do país receptor da missão) pudessem compartilhar informações sobre suas estratégias, ações e planos (NEVES, 2009, p.112).

A Peacebuilding Commission could perform the following functions: in the immediate aftermath of war, improve United Nations planning for sustained recovery, focusing on early efforts to establish the necessary institutions; help to ensure predictable financing for early recovery activities, in part by providing an overview of assessed, voluntary and standing funding mechanisms; improve the coordination of the many post-conflict activities of the United Nations funds, programmes and agencies; provide a forum in which the United Nations, major bilateral donors, troop contributors, relevant regional actors and organizations, the international financial institutions and the national or transitional Government of the country concerned can share information about their respective post-conflict recovery strategies, in the interests of greater coherence; periodically review progress towards medium-term recovery goals; and extend the period of political attention to post-conflict recovery (ONU, 2000, §115, grifos nossos apud NEVES, 2009, pp.112-113).

Desse modo, a proposta de criação da Comissão de Peacebuilding, iniciada em 2004, pelo relatório do Painel de Alto Nível, e confirmada no 
relatório produzido por Kofi Annan, foi ao debate em abril de 2005 entre as 191 delegações dos países membros das Nações Unidas (NEVES, 2009, p.119)- o que culminaria em sua posterior aprovação, em 2006.

Da perspectiva brasileira, a criação do novo órgão constituía uma

oportunidade singular de valorização de suas credenciais como ator relevante no cenário internacional, em múltiplas dimensões: per se, em função de seu peso econômico e populacional; como agente de projeção da presença latinoamericana nas Nações Unidas; como elemento de aglutinação de posições entre países em desenvolvimento; e no fortalecimento da ordem multilateral, por oposição ao utilitarismo de países mais influentes (NEVES, 2009, p.119).

Ainda é possível acrescentar que a Comissão ofereceria um espaço fundamental para o exercício de liderança do Brasil no campo do desenvolvimento. E, por último, seria um elemento que poderia servir de catalisador de reformas mais profundas. Todas essas expectativas ainda estão presentes e configuram os principais motivos do forte apoio do país ao fortalecimento da Comissão. No entanto, o governo brasileiro aponta que o texto final de aprovação da Comissão reduziu o órgão a um caráter "estritamente consultivo, sem autonomia para determinar sua própria agenda ou gerir recursos" (NEVES, 2009, p.141). Dessa forma, a Comissão não conseguiu ainda criar o espaço institucional necessário para uma atuação efetiva.

O Itamaraty tem defendido - ao longo de toda a década de 90 e até hoje duas questões de forma simultânea: i) a inclusão efetiva da Agenda para o Desenvolvimento nas operações de paz; e ii) a revisão da abordagem securitária dada ao desenvolvimento pelas Nações Unidas. Sobre esta segunda questão, o Brasil defende que as ações de peacebuilding devem estar presentes durante todo o mandato das operações de manutenção da paz, "suas atividades sendo incrementadas gradualmente, enquanto vão sendo asseguradas condições mínimas de segurança no terreno" (NEVES, 2009, p.122).

Além disso, o governo brasileiro tem ressaltado "a necessidade de dar maior atenção às causas fundamentais e à recuperação econômico-social em países emergentes de conflitos, em estado de conflito ou em vias de experimentar conflito" (NEVES, 2009, p.25). Defende-se, então, que as atividades pós-conflito - mesmo sendo ações de prevenção - já chegam um pouco tarde e que a 
preocupação com o desenvolvimento também deve estar presente antes da ocorrência de conflito - justamente para evitá-lo. Essa observação já tinha sido feita à época da Agenda para a Paz e foi incluída nos textos e resoluções da ONU. Contudo, o Brasil tem defendido a efetiva aplicação desta ideia e o fortalecimento de uma visão preventiva e menos reativa.

Por isso, o país tem advogado por uma participação mais ativa do ECOSOC na conformação das operações de paz, assim como a revitalização do órgão (NEVES, 2009, p.121). Em discurso de novembro de 1999, no Conselho de Segurança, o Represente Permanente destacava que

There is no single formula for conflict prevention. Preventive actions, thus, are to be taken after an assessment of the specifics of each situation. If we are to develop an encompassing strategy, it will no doubt have to be based on a deep understanding of the multiple root causes of conflict (BRASIL, 1999 apud NEVES, 2009, p.122).

A valorização das atividades de longo prazo para consolidação da paz e o investimento nos alicerces e na sustentabilidade da paz tem sido uma posição constante da diplomacia brasileira no âmbito das negociações sobre as operações de paz. Tais pontos foram destacados na "Agenda para o Desenvolvimento" - o que foi considerado uma consequência dos esforços de Brasil e Índia para direcionar o foco institucional para questões de desenvolvimento, inclusive no tema da consolidação da paz pós-conflito. Como já foi analisado, havia uma percepção por parte do governo brasileiro de que as questões de segurança tinham ganhado um espaço excessivo no léxico da ONU, especialmente no relatório da “Agenda para a paz". O Brasil promoveu o "[...] o conceito de "construção da paz preventiva" (preventive peace-building), por intermédio de ações de fomento do progresso econômico e social, [conseguindo] mobilizar o Secretariado e os Estados membros na elaboração e discussão de uma "Agenda para o desenvolvimento" (NEVES, 2009, p.65). Contudo, Gilda Motta lembra que "Agenda para o Desenvolvimento" não recebeu a atenção devida (NEVES, 2009, p.120).

A política externa brasileira continuou a perseguir tal objetivo e, em 1999, o ECOSOC aprovou a criação - sugerida também pelo Brasil - do Grupo Consultivo Ad-Hoc para o Haiti. Segundo o Ministro Enio Cordeiro, "orgulhamo- 
nos do fato de que foi por iniciativa do Embaixador Celso Amorim que na resolução 1212 (1998) se incluiu um convite específico ao Conselho Econômico e Social para contribuir com a elaboração de um programa de apoio de longo prazo para o Haiti” (FONSECA JR. (org.), 2002, p.143). Dentro desse contexto, em 25 de novembro de 1998, o Brasil apoiou a extensão do mandato da Missão das Nações Unidas de Polícia Civil no Haiti (MIPONUH), “como uma estratégia preventiva que tem de incluir outros aspectos, especialmente a assistência econômica para a reconstrução e o desenvolvimento do Haiti” (FONSECA JR. (org.), 2002, p.141, grifo nosso). Celso Amorim sublinha que

o Haiti, mas também o sistema como um todo, pode beneficiar-se dessa nova ênfase no papel do Conselho Econômico e Social. [...] E isso pode aplicar-se a outra áreas, especialmente ao que chamamos aqui de "construção da paz pósconflito" (FONSECA JR. (org.), 2002, p.142, grifo nosso).

Ainda em 1999, o Conselho de Segurança endossou a iniciativa do Secretário-Geral de estabelecer Escritório da ONU em Guiné-Bissau (UNOGBIS) com mandato para consolidar a paz e o estado de direito e assistir na organização de eleições. Com a participação brasileira, o Grupo Ad-Hoc para Guiné-Bissau foi criado em 2002 pelo ECOSOC. Gilda Motta aponta que os Grupos Ad-Hoc do ECOSOC para países em situação de conflito podem ser considerados os precursores da Comissão para Consolidação da Paz.

No contexto de negociação da Comissão para Consolidação da Paz, havia uma forte preferência do governo brasileiro em promover a participação intensa do ECOSOC no órgão e conter o avanço do Conselho de Segurança (NEVES, 2009, p.120). Essa preferência se baseava em dois argumentos: o CSNU tinha pouca representatividade (e legitimidade) e não era de sua competência tratar de temas sociais e econômicos. Contudo, durante todas as rodadas de negociações, Estados Unidos, Reino Unido, França, China e Rússia (os P-5) apoiaram pela exclusividade de subordinação da Comissão ao Conselho de Segurança. Este funcionaria como órgão subsidiário, de acordo com o artigo 29 da Carta das Nações Unidas: “O Conselho de Segurança poderá estabelecer órgãos subsidiários que julgar necessários para o desempenho de suas funções" (ONU, 1945, pp.2021). 
De um lado, estavam os chamados "ocidentais" e do outro os países em desenvolvimento, "preocupados em fortalecer os órgãos mais democráticos das Nações Unidas, como a Assembleia Geral e o ECOSOC" (NEVES, 2009, p.123). Inicialmente, o projeto de Documento Final da Cúpula foi examinado em sessões plenárias informais na Assembleia Geral. Neste momento, o Brasil defendeu os princípios tradicionais de sua posição, indicando que a Comissão para Consolidação da Paz deveria reportar-se tanto ao Conselho de Segurança, quanto ao ECOSOC:

Threats to peace and security include not only international war and conflict but also civil violence, organized crime, terrorism, poverty and deadly infectious diseases. This new concept of collective security can help provide the tools needed to meet the most compelling contemporary threats to humanity.

The UN must be more effective in preventing conflict and reducing the risk and prevalence of war by addressing their root causes. Prevention must be central in our efforts, and this would necessarily include combating poverty and promoting sustainable development.

The proposed establishment of a Peace-building Commission is a concrete expression of such a vision. Brazil has for a long time affirmed the need that due consideration be paid to transitional processes, from post-conflict to sustainable peace. We view positively the functions foreseen by the SecretaryGeneral for such a Commission, as set out in paragraph 115 . We believe that the Commission, in order to bring together the objectives of peace, security and development, should respond to both the Security Council and the ECOSOC, in a sequential manner, depending on the phase of the conflict ${ }^{36}$.

A partir daí e durante toda a negociação, ${ }^{37}$ a delegação brasileira defendeu que a Comissão fosse "independente e propositiva, de assessoria tanto ao Conselho de Segurança, quanto ao ECOSOC, e com liberdade para estudar os assuntos que lhe parecessem relevantes e apresentar recomendações aos órgãos e instituições que lhe parecesse importante acionar" (NEVES, 2009, p.141). No

\footnotetext{
${ }^{36}$ Telegrama 819 de Delbrasonu, de 07 de abril de 2005 apud NEVES, 2009, p.124.

${ }^{37}$ Sem a intenção de aprofundar este assunto, mas percebendo este ser um tema fundamental para o estudo das grandes negociações multilaterais, vale a pena iluminar que, segundo Neves, os países em desenvolvimento têm alertado para o fato de ter se tornado comum sistemas de negociação cuja rapidez e urgência se sobrepõem a legitimidade e transparência. A diplomata alerta que os países desenvolvidos ganham vantagem neste momento em relação à estrutura das delegações, pois possuem maior número de delegados e maior infraestrutura operacional e técnica, inclusive pessoal de apoio e de pesquisa. Desse modo, "enquanto o delegado de um país pequeno move-se de sala em sala para acompanhar temas inteiramente diversos, as missões dos países desenvolvidos dispõem normalmente de mais de um delegado para seguir cada tema, além de suficiente pessoal de apoio na sede" (NEVES, 2009, p. 125). Segundo a diplomata, este foi o caso da rodada de negociações para a criação da PBC.
} 
documento final aprovado pela Assembleia Geral e depois pelo Conselho, esses pontos centrais não foram atendidos. Em relação à composição, a delegação brasileira defendeu uma distribuição geograficamente equilibrada dos assentos. Nas resoluções, "há claramente um deficit de assentos para a América latina e superavit de assentos para o WEOG, ${ }^{\mathbf{3 8}}$ em particular o grupo europeu" (NEVES, 2009, p.201). Além disso, o Brasil defendeu que a escolha de membros da Comissão deveria ocorrer por processo eletivo e não seletivo, como acabou prevalecendo.

Em relação à agenda, a delegação brasileira defendeu que a Comissão tivesse capacidade proativa, de determinar sua própria agenda, e não apenas um caráter consultivo como está no art. $1^{\circ}$ (advisory body) da Resolução 60/180 (ONU, 2005b), aprovada pela Assembleia Geral (NEVES, 2009, p.202). A busca pelo equilíbrio regional da agenda também tem sido uma reivindicação brasileira, para que a primazia dada ao CSNU para incluir temas na agenda seja substituída. ${ }^{39}$ Por último, a diplomata Gilda Motta enfatiza a função preventiva da Comissão que poderia ser mais bem aproveitada se "com adequada assessoria técnica do PBSO, [pudesse] viabilizar o contato antecipado com autoridades nacionais em países sob risco de entrar em situação de conflito, para avaliar sua disposição de aceder à colaboração das Nações Unidas" (NEVES, 2009, p.203). De forma complementar, a diplomata faz uma declaração que indica a nova postura da política externa brasileira sobre a questão da intervenção e direitos humanos, e mais especificamente, sobre o conceito de Responsabilidade de Proteger: amplo apoio à defesa e proteção do humanitarismo e dos direitos humanos, mas sem se comprometer sobre o problema do uso da força.

Não se admite que no século XXI ainda seja possível sucumbir a catástrofes humanas das dimensões de Darfur. [...] Por outro lado, o próprio conceito de soberania poderá merecer, no futuro, revisão à luz da evolução das discussões acerca da "responsabilidade de proteger". Claro está que são fundamentais todas as garantias para preservar a independência e soberania dos países, mas também o são a detecção de violações generalizadas de direitos humanos e crimes contra a humanidade e a proteção do ser humano contra a

\footnotetext{
38 "Grupo da Europa Ocidental e Outros" (WEOG), "que inclui União Europeia, Estados Unidos, Japão, Canadá, Nova Zelândia e Austrália e conforma o grupo de 'ocidentais', a que se associam os Estados da chamada Europa Oriental (grupo em que ainda estão, para efeitos de distribuição regional na ONU, muitos países que agora fazem parte da União Europeia ou estão em processo de acessão ao bloco)" (NEVES, 2009, p. 128).

${ }^{39}$ Cf. artigo 12, alínea "a", combinado ao artigo 16.
} 
indiferença do Estado ou sua atuação genocida (NEVES, 2009, p.203, grifo nosso).

O Brasil votou a favor da resolução 60/180 (ONU, 2005b) na Assembleia e a favor da Resolução 1645 (ONU, 2005d) no Conselho de Segurança, que só reforçou a primeira. E absteve-se na Resolução imediatamente subsequente do Conselho, a 1646 (ONU, 2005c), aprovada com 13 votos a favor (Argélia, Benin, China, Dinamarca, Estados Unidos, Federação Russa, Filipinas, França, Grécia, Japão, Reino Unido, Romênia e Tanzânia) e duas abstenções, Brasil e Argentina (NEVES, 2009, pp. 142-143). A resolução 1646 (ONU, 2005c) estabelece que os membros permanentes do Conselho de Segurança também podem fazer parte da composição do órgão, como é possível conferir a seguir:

Decides pursuant to paragraph 4 (a) of resolution 1645 (2005) that the permanent members listed in article 23 (1) of the Charter shall be members of the Organizational Committee of the Peacebuilding Commission and that, in addition, the Council shall select annually two of its elected members to participate in the Organizational Committee (ONU, 2005c, § 1).

O Embaixador Ronaldo Sardenberg esclareceu o voto da delegação brasileira: "Brazil has voted abstention on the subsequent resolution because it departs from the principles agreed upon concurrently by the GA and the Security Council in resolution 1645".40 Da mesma forma, o Embaixador César Mayoral completou:

la decisión de incluir a los membros del Consejo de Seguridad en la composición de ese órgano, tal y como se establece en la segunda resolución que hemos aprobado, 1646 (2005), nos impidió estar a favor de ella, ya que la Argentina, mi país, ha defendido desde la creación de esta Organización el principio de la igualdad jurídica de los Estados como emblema, y está en contra del establecimiento de cualquier privilegio ${ }^{41}$

\footnotetext{
${ }^{40}$ Telegrama 3608 de Delbrasonu, de 20 de dezembro de 2005 apud NEVES, 2009, p. 143.

${ }^{41}$ Transcrição da sessão do Conselho de Segurança. Documento S/PV.5335, 20 dez. 2005 apud NEVES, 2009, p. 143
} 
Durante o primeiro ano de trabalho da Comissão, o Brasil buscou incluir países como o Haiti e Timor-Leste, além de Guiné-Bissau na agenda da Comissão. Caso isso ocorresse, especialmente no Haiti, haveria um fortalecimento da atuação das tropas brasileiras no terreno e o envolvimento do Brasil na PBC seria mais intenso - "o que além dos objetivos diretos para a consolidação da paz no país, traria o benefício adicional de fortalecer o princípio da interdependência entre estabilização da segurança, reconciliação social e reconstrução institucional e econômica" (NEVES, 2009, pp.166-167). Além disso, a atuação da Comissão no Haiti, com liderança brasileira, consolidaria a proposta do Brasil por uma nova abordagem nas operações de manutenção da paz. Contudo, nenhum dos três países demonstrou interesse em ser objeto do trabalho da Comissão:

[...] talvez por receio de que a iniciativa acelerasse sua saída da agenda do Conselho de Segurança, que comanda maior atenção internacional, talvez em razão de não perceberem valor agregado em ser objeto de exame da Comissão, que só acrescentaria, dessa perspectiva, mais um nível de interlocução com a comunidade internacional (além do Conselho de Segurança, do Grupo Ad-Hoc, do "Grupo de Amigos", doadores institucionais e individuais, organismos não governamentais, e a presença da ONU no país, em todas suas manifestações) (NEVES, 2009, p.166).

Também muito tem se discutido sobre a necessidade de coordenação dos atores envolvidos no esforço de consolidação da paz porque isso significa não apenas o esforço de "fazê-los sentar a mesma mesa" (NEVES, 2009, p.167), como também de "viabilizar a complementaridade e reforço mútuo dos projetos de assistência. Até o momento essa tarefa revelou-se elusiva e parece haver resistência não só técnica, mas também política, a que o Escritório de Apoio realize levantamento abrangente de todas as iniciativas em curso no terreno" (NEVES, 2009, p.167).

Diante desta realidade, a diplomata Gilda Motta indica que o Brasil deve continuar a defender a reforma da Comissão para um mandato ampliado para que seja possível uma atuação efetiva na prevenção de conflitos, além disso:

a independência do órgão como capacidade propositiva e proativa; e o entendimento de peacebuilding como conjunto de atividades relevantes em todas as fases de tratamento do conflito - inclusive atuação pré-conflito - em oposição 
à visão restritiva e sequencial preferida pelos países ocidentais e pela atual chefe do Escritório de Apoio (NEVES, 2009, p.184).

Desse modo, percebe-se um esforço do governo brasileiro em redirecionar o foco da segurança para o desenvolvimento; e das práticas de intervenção para as ações de prevenção. O forte apoio à Criação da Comissão de Peacebuilding teve esse propósito, apesar dos resultados até o momento não terem correspondido às expectativas brasileiras iniciais de aproveitar esse espaço para exercer liderança. Ao mesmo tempo em que o Brasil busca resistir ao avanço das práticas de intervenção, também parece se alinhar aos preceitos liberais da governança internacional no que concerne às práticas de peacebuilding, uma vez que participa e incentiva ativamente a construção da paz liberal, que tem por objetivo uma agenda radical de transformação social, e que, a saber:

combina e mescla "liberal" (como nas doutrinas liberais políticas e econômicas contemporâneas) com "paz" (a atual predileção política com vistas à resolução de conflitos e à reconstrução social). Reflete o atual consenso de que a melhor abordagem para o conflito no Sul é um conjunto de medidas conectadas de melhoria, harmonização e, especialmente, transformação. Ainda que isso possa incluir a provisão de alívio imediato e assistência para a reabilitação, a paz liberal incorpora um humanitarismo novo, ou político, que dá ênfase a coisas como resolução e prevenção de conflitos, reconstrução de redes sociais, fortalecimento de instituições civis e representativas, promoção do primado da lei e reforma do setor de segurança no contexto de uma economia de mercado efetiva. Em muitos aspectos, ainda que contestada e longe de estar garantida, a paz liberal reflete uma agenda radical de desenvolvimento e transformação social (DUFFIELD, 2001, p.11, tradução Letícia SOUZA). 


\section{Conclusão}

Desde o fim da ditadura, em 1985, o Brasil tem buscado o alinhamento aos princípios liberais e democráticos, como afirmou Fernando Henrique Cardoso: “o Brasil que entra no século XXI é um país cujos objetivos prioritários de transformação interna, de desenvolvimento, estão em consonância com os valores que se difundem e se universalizam no plano internacional" (2000, p.6 apud VIGEVANI; OLIVEIRA; CINTRA, 2003, p.36). Simultaneamente, o país buscou alcançar a autonomia, no sentido da afirmação das especificidades da posição e do papel brasileiro em âmbito regional e global (HERZ, 2011, p.3). Tal estratégia foi denominada de autonomia por integração (VIGEVANI; OLIVEIRA; CINTRA, 2003), sendo o resultado de uma participação ativa do Brasil na organização e na regulamentação das relações internacionais, nas mais diversas áreas.

O Brasil tem agido, a partir de então, em conformidade com os valores democráticos liberais, e, sobretudo, como um ator relevante na promoção desses valores. A defesa pelo componente de desenvolvimento nas operações de paz é apresentada por diplomatas como uma abordagem específica e alternativa, cujo foco se concentra na responsabilidade coletiva e não na segurança coletiva. Amorim e Patriota definem responsabilidade coletiva como sendo a responsabilidade da comunidade internacional no combate às raízes dos conflitos, relacionadas com o problema do subdesenvolvimento, e no uso de medidas não coercitivas para exercer tal responsabilidade.

Propõe-se, então, uma releitura do conceito de segurança humana, "[...] in order to exclude the use of force as a "viable" way to build peace and attain human security and, finally, to insist on UN Charter original text" (ESTEVES, 2012a, p.13). Entretanto, o Brasil defende a mesma ideia de desenvolvimento apresentada no primeiro Relatório de Desenvolvimento Humano do PNUD, em que se definiu por desenvolvimento sustentável a promoção dos direitos humanos - econômicos, políticos, civis e culturais (BRASIL, 2010). As atividades de desenvolvimento costumam abranger, entre outros temas, a reconstrução da capacidade do Estado de governar, o que inclui o fortalecimento das instituições e de sua capacidade de formular e implementar políticas públicas, a partir de um modelo democrático liberal. Segundo a ONU, "a democracia cria condições para

que a proteção dos direitos fundamentais dos cidadãos fique assegurada. É ela que 
provê a base mais sólida para a paz e a estabilidade nas relações internacionais" (COMISSÃO SOBRE GOVERNANÇA GLOBAL, 1996, p.43).

Dessa forma, o engajamento da política externa brasileira nas atividades relacionadas à reconstrução demonstra uma convergência com as normas estabelecidas pelas Nações Unidas. Desde o fim do regime militar, o Brasil tem defendido e atuado fortemente a favor da democracia, e, desde 1945, vem adotando posição proativa nas negociações sobre comércio e desenvolvimento (LIMA; HIRST, 2009, p.45).

Em relação ao campo das operações de paz, o governo Lula (2003-2010) inaugurou novas estratégias de atuação, resultando na participação brasileira no comando de uma missão de paz aprovada com base no Capítulo VII da Carta, a MINUSTAH. A adoção do conceito de "não indiferença" como um complemento ao princípio da "não intervenção" permitiu tal engajamento, alinhando o país aos preceitos liberais da governança internacional no que concerne às práticas de peacebuilding, enquanto permite que o Brasil continue a resistir aos avanços da agenda de intervenção, mas de uma forma bastante flexível.

A participação do Brasil na MINUSTAH pode ser vista como uma estratégia para tentar exercer liderança através da elaboração de uma nova abordagem para as operações de paz, em que o desenvolvimento seja o elemento norteador de toda a ação. Mas como ressaltou Mônica Herz, apesar da tentativa de propor uma nova abordagem para as operações de paz, o país não parece ter como objetivo oferecer alternativas ao atual sistema de governança global, "seeking instead increased status within the established system" (HERZ, 2011, p.27).

Segundo Mônica Herz, pode-se dizer que o Brasil busca a convergência de sua política com as normas internacionais, embora procure igualmente transformar tais normas, a partir das margens. Isso é particularmente verdade no âmbito das operações de paz, em que o Brasil tem buscado se engajar mais com o tema da intervenção para, ao mesmo tempo, propor uma abordagem focada no desenvolvimento - cujo foco se concentra em ações de reconstrução ampla das instituições e da infraestrutura dos Estados, de acordo com princípios de democracia e boa governança.

Tal abordagem se baseia na ideia de "paz liberal" - que dá ênfase a coisas como "resolução e prevenção de conflitos, reconstrução de redes sociais, fortalecimento de instituições civis e representativas, promoção do primado da lei 
e reforma do setor de segurança no contexto de uma economia de mercado efetiva" (DUFFIELD, 2001, p.11, tradução Letícia SOUZA).

Segundo Oliver Richmond (2010), a paz liberal oscila de uma versão liberal altamente intervencionista para versões mais consensuais que incorporem preocupações com a justiça social. Para o autor, todas essas facetas da paz liberal têm gradações de consenso e condicionalidade, entretanto, todas compartilham uma premissa da universalidade, que legitima a intervenção, e da superioridade da comunidade epistêmica da construção de Estados sobre seus recipientes.

Oliver Richmond (2010) acredita que a ideia de paz liberal parte de uma premissa de universalidade e superioridade da comunidade ocidental. Nesse sentido, Duffield (2001, p.12) afirma que a promoção e a preservação dessa paz ocorrem pela atuação de complexos estratégicos, "of state-non-state, militarycivilian and public-private actors in pursuit of its aims." Nessa rede de atores, estão "organizações internacionais, governos, instituições financeiras internacionais, o setor privado, think-tanks influentes, entre outros, que podem ser considerados estratégicos no sentido de perseguirem uma agenda radical de transformação social em busca da estabilidade global” (DUFFIELD, 2001, p.12, tradução nossa).

Richmond (2010) alerta que a universalização do modelo de democracia liberal impõe um conceito de paz ontologicamente estável e naturalizado, sendo preciso pensar em algumas questões essenciais: quem cria e promove essa paz; por quais motivos; em nome de quais interesses e para quem. Segundo Duffield (2001, p.11), a paz liberal pode ser entendida como um projeto político, com o objetivo de prevenir conflitos e "transformar as sociedades disfuncionais e afetadas pela guerra que se encontram em suas fronteiras em entidades cooperativas, representativas e, especialmente, estáveis." Dessa forma, peacebuilding seria a imposição de um modelo de vida, política, economia, e, especialmente, de um modelo particular de governança doméstica baseada em democracia e economia liberal.

A perspectiva crítica ao modelo de paz liberal contribui para a reflexão sobre o limite da abordagem "desenvolvimentista" defendida pelo Brasil, que segue em contraponto a uma abordagem coercitiva, com base no uso da força. Afinal, não seria o modelo de paz liberal a maior forma de coerção? 


\section{Referências Bibliográficas}

ABIEW, Francis Kofi. (1999). The Evolution of the Doctrine and Practice of Humanitarian Intervention. Boston: Kluwer Law International, 1999.

ACHARYA, Amitav. (1994). The Periphery as the Core: The Third World and Security Studies. Toronto: York University, 1994.

ALMEIDA, Paulo Roberto de. (2011). Liderança e hegemonia: reflexões a partir do Brasil (8). Observador Político. 26 dez. 2011. Disponível em:<http://www.observadorpolitico.org.br/2011/12/lideranca-e-hegemoniareflexoes-a-partir-do-brasil-8/>. Acesso em: 16 jan. 2012.

AMORIM, Celso. (2011). Conversas com jovens diplomatas. São Paulo: Benvirá, 2011.

. (2010). Política externa é uma política pública como as demais. Está sujeita à expressão das urnas. Desafios do Desenvolvimento - Ipea, maio/junho 2010, Ano 7, № 61, pp.10-21. Entrevista. Disponível em: $<$ http://www.ipea.gov.br/003/00301009.jsp?ttCD_CHAVE=14709> Acesso em: 20 set. 2012.

. (2005). Política Externa do Governo Lula: os dois primeiros anos.

Análise de Conjuntura OPSA (Observatório Político Sul-Americano), ํo 4, março 2005.2 Disponível em: <http://www.gedes.org.br/downloads/992abee1f32006ceb57149d0d659f1 32.pdf> Acesso em: 15 set. 2012.

- (2004). Conceitos de Segurança e Defesa - implicações para a ação interna e externa do governo. In: PINTO, J.R. de Almeida; ROCHA, A.J. Ramalho da; SILVA, R. Doring Pinho da (Eds). Reflexões sobre defesa e segurança: uma estratégia para o Brasil. Brasília: Ministério da Defesa, 2004.

(2004a). The foreign policy of the Lula government. Lecture given at the London School of Economics, 17 March 2004a. Disponível em: <http://www.brazil.org.uk/press/articles_files/20040317.html>. Acesso em: 15 nov. 2011. 
. (2003). A diplomacia do governo Lula. Palestra no Instituto Rio Branco, 10 abril 2003. In: HOFMEISTER, Wilhelm (Org.), Anuário BrasilEuropa. Rio de Janeiro: Konrad-Adenauer-Stiftung, 2004.

- (1998). Pronunciamento do Embaixador Celso Amorim como Representante Permanente na Delegação Brasileira ao Conselho de Segurança 1998-1999, 16 dez. 1998. In: FONSECA JR. Gelson (Org.). 0 Brasil no Conselho de Segurança da ONU. 1998-1999. Coleção Questões Internacionais, 1. Brasília: IPRI/FUNAG, 2002.

ANNAN, Kofi. (1999). Two Concepts of Sovereignty. The Economist, v.352, 18 Sept. 1999, pp. 49-50.

. (2005). In Larger Freedom: Towards Security, Development and Human Rights for All. New York: United Nations, 2005.

ARENDT, Hannah (2008). Homens em tempos sombrios. São Paulo: Companhia das Letras, 2008.

BARNETT, Michael; WEISS, Thomas G. (2008). Humanitarianism in Question: Power, Politics, Ethics. New York: Cornell University, 2008.

BETTATI, Mario. (1996). Le droit d'ingérence: mutation de l'ordre international. Paris: O. Jacob, 1996.

BIGO, Didier et al. (2009). (In)security practices. Compendium on line of the International Studies Association, 2009.

BIGO, Didier. (2008). International political sociology. In: WILLIAMS, Paul (Org.). Security Studies: an introduction. New York: Routledge, 2008, pp. 116-129.

BIGO, Didier; TSOUKALA, Anastassia. (2008a). Understanding (in)Security. In: __. Terror, Insecurity and Liberty. Illiberal Practices of Liberal Regimes after 9/11. Oxon and New York: Routledge, 2008a.

BIGO, Didier; WALKER, R.B.J. (2007). International, Political, Sociology. In: International Studies Association. Oxford: Blackwell Publishing, 2007. 
BYERS, Michael. (2007). A lei da Guerra: Direito Internacional e Conflito Armado. Rio de Janeiro: Editora Record, 2007.

BOYLE, Joseph. (2006). Traditional Just War Theory and Humanitarian Intervention. In: NARDIN, Terry; WILLIAMS, Melissa S. (Orgs.). Humanitarian Intervention. New York: New York University Press, 2006, pp. 32-54.

BRASIL. (2012). Pronunciamento do Ministro das Relações Exteriores Antonio Patriota em debate sobre Responsabilidade de Proteger, $21 \mathrm{fev}$. 2012. Disponível em <http://www.itamaraty.gov.br/sala-deimprensa/notas-a-imprensa/pronunciamento-do-ministro-das-relacoesexteriores-antonio-de-aguiar-patriota-em-debate-sobre-responsabilidadeao-proteger-na-onu-2013-nova-york-21-de-fevereiro-de-2012>. Acesso em: 06 março 2012.

(2010) Discurso do Ministro Celso Amorim por ocasião da Sessão Especial do Conselho de Direitos Humanos sobre o Haiti - Genebra, 27 jan. 2010. Disponível em: <http://www.itamaraty.gov.br/sala-deimprensa/discursos-artigos-entrevistas-e-outras-comunicacoes/ministroestado-relacoes-exteriores/494723400879-discurso-do-ministro-celsoamorim-por-ocasiao-da> Acesso em: 9 março 2012.

(2010a). Statement by H.E. Ambassador Maria Luiza Ribeiro Viotti Permanent Representative of Brazil to the United Nations. Informal Interactive Dialogue on the Responsibility to Protect. New York, 23 July 2010a. Disponível em: <http://www.un.int/brazil/speech/10d-mlrv-informalinteractive-dialogue-on-the-responsability-to-protect.html> Acesso em: 12 março 2012.

. (2006). Celso Amorim. Ministro das Relações Exteriores. Discurso por ocasião da XXXVI Assembleia-Geral da OEA, em São Domingos, República Dominicana, 5 jun. 2006. Disponível em: <http://www.mre.gov.br/portugues/politica_externa/discursos/discurso_det alhe3.asp?ID_DISCURSO=2853 > . Acesso em: 14 março 2012.

(2005). Celso Amorim. Ministro das Relações Exteriores. Discurso na abertura do debate geral da 60aㄴ LX Sessão da Assembleia Geral das Nações Unidas em Nova lorque, 17 set. 2005. Disponível em: $<$ http://www.itamaraty.gov.br/divulg/documentacaodiplomatica/publicacoes/discursos-palestras-artigos/arquivos/discursoschanceler-vol1/>. Acesso em: 5 fev. 2012. 
(2005a). Ministério da Defesa. Política de Defesa Nacional. Brasília: Ministério da Defesa, 2005a, parágrafos 2.3, 4.12. Disponível em: $<$ http://www.planalto.gov.br/ccivil_03/_Ato2004-

2006/2005/Decreto/D5484.htm>. Acesso em: 12 fev. 2012.

(2005b). Missão Permanente nas Nações Unidas. Assembleia Geral. $59^{\mathrm{a}}$ Sessão. Cluster III: Freedom to Live in Dignity. Statement by Ambassador Ronaldo Sardenberg, Permanent Representative of Brazil to the UN. New York, 19/20 April 2005b. Disponível em: $<$ http://globalr2p.org/media/pdf/Brazil_Statement_made_at_informal_discu ssions_at_the_GA_in_advance_of_the_World_Summit.pdf>. Acesso em: 10 fev. 2012 .

(2003). Celso Amorim. Ministro das Relações Exteriores. O Brasil e os novos conceitos globais e hemisféricos de segurança. Itaipava-RJ, 11 e 12 out. 2003. Disponível em: $<$ http://www.itamaraty.gov.br/divulg/documentacao-

diplomatica/publicacoes/discursos-palestras-artigos/arquivos/discursoschanceler-vol1/> Acesso em: 10 fev. 2012.

. (1999). Intervenção do Embaixador Gelson Fonseca Junior no CSNU, sessão formal de 29 de novembro de 1999 sobre O Papel do Conselho de Segurança na Prevenção de Conflitos. Disponível em: <www.un.int/brazil/speech/99d-gfj-csnu-prevention-of-conflicts.htm> Acesso em 7 fev. 2012.

(1996). Ministério da Defesa. Política de Defesa Nacional. Brasília:

Ministério da Defesa, 1996; parágrafo 2.3. Disponível em: <http:// merln.ndu.edu/whitepapers.html>. Acesso em: 5 set. 2012.

(1988). Constituição do Brasil: promulgada em 5 out. 1988/ obra coletiva de autoria da Editora Saraiva com a colaboração de Luiz Roberto Curia, Livia Céspedes e Juliana Nicoletti. 47. ed. atual. e ampl. São Paulo: Saraiva, 2012. - (Coleção Saraiva de legislação).

BUZAN, Barry; WAEVER, Ole; WILDE, Jaap de. (1998). Security: A New Framework for Analysis. Londres: Lynne Rienner Publishers, 1998.

CABRANES, José A. (1967). Human Rights and Non- Intervention in the Inter-American System. Michigan Law Review. Vol. 65, 1967, pp. 11471182. 
CÂMARA, Irene Pessôa de Lima. (1998). Em nome da democracia. A OEA e a crise haitiana - 1991-1994. Brasília: IRB/FUNAG; Centro de Estudos Estratégicos, 1998.

CARDOSO, Fernando Henrique. (2000). Palestra do senhor presidente da República, Fernando Henrique Cardoso, no Centro Brasileiro de Relações Internacionais (Cebri). Rio de Janeiro, 14 set. 2000. Disponível em <http://ftp.unb.br/pub/UNB/ipr/rel/discpr/2000/2929.pdf>. Acesso em: 5 fev. de 2012.

COMISSÃO SOBRE SEGURANÇA HUMANA. (2003). Human Security Now, 2003. Disponível em <http://ochaonline.un.org/humansecurity/CHS/finalreport/index.html>. Acesso em: 5 março 2011.

COMISSÃO SOBRE GOVERNANÇA GLOBAL. (1996). Nossa Comunidade Global. Rio de Janeiro: Editora da Fundação Getúlio Vargas, 1996.

CARTA DA ORGANIZAÇÃO DOS ESTADOS AMERICANOS (OEA). (1948). Disponível em: <http://www.oas.org/dil/treaties_A41_Charter_of_the_Organization_of_American_States.htm\#ch6>. Acesso em: 9 março 2012.

CARVALHO, Amanda Sanches Daltro de; ROSA, Renata de Melo. (2011). O Brasil e a não-indiferença à crise haitiana: solidariedade ou retórica do discurso? Univ. Rel. Int., Brasília, v. 9, n. 1, p. 487-509, jan./jun. 2011. Disponível em: $<$ http://www.sumarios.org/sites/default/files/pdfs/64230_7277.PDF>. Acesso em: 18 fev. 2012.

COSTA, Antonio Luiz M. C. (2011). Brasil: sexta economia do mundo. Carta Capital, 09 nov. 2011. Disponível em <http://www.cartacapital.com.br/economia/brasil-sexta-economia-domundo/> Acesso em: 10 fev. 2012.

COX, Robert. (1989). Middlepowermanship, Japan, and Future World Order. International Journal, vol.44, $\mathrm{n}^{\circ} 4,1989$.

DENG, Francis et al (1996). Sovereignty as Responsibility. Brookings Institution Press, 1996. 
DEPARTMENT OF PEACEKEEPING OPERATIONS; DEPARTMENT OF FIELD SUPPORT. (2008). Capstone Doctrine. New York, 2008. Disponível em <http://pbpu.unlb.org/pbps/Library/Capstone_Doctrine_ENG.pdf>. Acesso em: 12 fev. 2012.

DER DERIAN J.; SHAPIRO, M. J. (Eds.). (1989). International/Intertextual Relations: Postmodern Readings of World Politics. New York: Lexington Books, 1989.

DIEHL, Paul. (2008). Peace Operations. Malden, MA: Polity Press, 2008.

DUFFIELD, Mark. (2001). Global Governance and the New Wars: The Merging of Development and Security. London: Zed Books, 2001.

ESTEVES, Paulo. (2012). Operações de Manutenção da Paz sob o Programa da Paz Democrática, no prelo, 2012.

. (2012a). Sovereignty at the Periphery: beyond the anxiety of autonomy? No prelo, 2012a. . (2012b). The Meanings of Non-indifference, no prelo, 2012b.

EVANS, Gareth. (2008). The Responsibility to Protect: Ending mass atrocity crimes once and for all. Washington, D.C.: The Brookings Institution, 2008.

EVANS, Gareth; SAHNOUN, Mohamed. (2002). The responsibility to protect. Foreign Affairs, v. 81, n.6, November/December 2002, pp.99110. Disponível em: <http://www.foreignaffairs.com/articles/58437/garethevans-and-mohamed-sahnoun/the-responsibility-to-protect>. Acesso em: 5 março 2012.

FAUSTO, Boris. (1994). História do Brasil. São Paulo: EDUSP, 1994.

FIERKE, K.M. (2007). Critical Approaches to International Security. Cambridge: Polity Press, 2007. 
FILHO, Wladimir Valler. (2007). O Brasil e a Crise Haitiana: a cooperação técnica como instrumento de solidariedade e de ação diplomática. Brasília: FUNAG, 2007.

FINNEMORE, Martha. (2003). The Purpose of Intervention: Changing Beliefs About the Use of Force. Ithaca: Cornell University Press, 2003.

(1996). Constructing Norms of Humanitarian Intervention. pp. 174175. In: KATZENSTEIN, Peter (Org.). The culture of National Security. Ithaca: Cornell University Press, 1996, p. 153-185.

FONSECA JR., Gelson. (1998). A Legitimidade e Outras Questões Internacionais. Rio de Janeiro: Paz e Terra, 1998.

FONSECA JR. Gelson (Org.). (2002). O Brasil no Conselho de Segurança da ONU. 1998-1999. Coleção Questões Internacionais, 1. Brasília: IPRI/FUNAG, 2002.

FOUCAULT, Michel. (2005). Ditos e Escritos, Vol. II: Arqueologia das Ciências e História dos Sistemas de Pensamento. 2. ed. Rio de Janeiro: Forense Universitária, 2005.

GOLDSTONE, R.J. (2000). For Humanity: Reflections of a War Crimes Investigator. New Haven and London: Yale University Press, 2000.

HANSEN, Lene. (2006). Security as Practice: Discourse Analysis and the Bosnian War. London: Routledge, 2006.

HAMPSON, Fen Osler. (2008). Human Security. In: WILLIAMS, Paul (Ed.) Security Studies: an Introduction. London: Routledge, 2008.

HALL, William Edward. (1880). International Law. 1a Ed. Oxford: Claredon Press, 1880. In: CHESTERMAN, Simon. Just War or Just Peace? Oxford: Oxford University Press, 2002.

HERZ, Mônica; HOFFMANN, Andrea Ribeiro. (2004). Organizações Internacionais. História e Práticas. Rio de Janeiro: Elsevier, 2004. 
HERZ, Mônica. (2002). Política de segurança dos EUA para a América Latina após o final da Guerra Fria. Estud. av. vol. 16, $n^{\circ}$. 46. São Paulo Sept./Dec, 2002. Disponível em: <http://dx.doi.org/10.1590/S010340142002000300007 > Acesso em: 10 out. 2011.

(2011). Brazil: Major Power in the Making? In: VOLGY, Thomas J. et al. Major powers and the quest for status in international politics: global and regional perspectives. New York: Palgrave Macmillan, 2011.

HIRST, Mônica. (1996). A Política Externa do Segundo Governo Vargas (1951-54). In: ALBUQUERQUE, J.A.G. (Coord.). Sessenta Anos de Política Externa Brasileira, 1930-1990 (vol.1). São Paulo: Núcleo de Pesquisa em Relações Internacionais-USP/Cultura Editores Associados, 1996, pp.211-230.

HOFFMANN, Stanley. (1996). Sovereignty and the Ethics of Intervention. In: _. The Ethics and Politics of Humanitarian Intervention. Notre Dame: Notre Dame University Press, 1996, pp.38-60.

HOLZGREFE, J. L. (2003). The Humanitarian Intervention Debate. In: HOLZGREFE, J. L; KEOHANE, Robert O. (Ed.). Humanitarian Intervention: Ethical Legal and Political Dilemmas. New York: Cambridge University Press, 2003, pp. 15-52.

INTERNATIONAL COMMISSION ON INTERVENTION AND STATE SOVEREIGNTY [ICISS]. (2001). The Responsibility to Protect: Report of the International Commission on Intervention and State Sovereignty. Ottawa: International Development Research Centre, 2001. Disponível em <http://responsibilitytoprotect.org//CISS\%20Report.pdf> Acesso em: 15 março 2012.

JASMIN, Marcelo G.; JÚNIOR, João F. (2006). História dos Conceitos: Debates e Perspectivas. Rio de Janeiro: Editora PUC-Rio: Edições Loyola: IUPERJ, 2006.

JORDAAN, Eduard. (2003). The Concept of a Middle Power in International Relations: Distinguishing between Emerging and Traditional Middle Powers. Politikon (Pretoria), vol. 30, nº 2, 2003.

KALDOR, Mary. (2007). Human Security: Reflections on Globalization and Intervention. Cambridge: Polity Press, 2007. 
. (2001). New \& Old Wars: organized violence in a global era. Stanford: Stanford University Press, 2001.

KENKEL, Kai Michael. (2012) O dilema interno da soberania: a evolução das normas de intervenção, no prelo, 2012.

. (2012a). Brazil and R2P: Does taking responsibility mean using force? No prelo, 2012a.

(2012b). Operações de paz: da 'tênue linha azul' até 'pintar um país de azul', no prelo, 2012b.

. (2010). South America's Emerging Power: Brazil as Peacekeeper. International Peacekeeping, vol.17, $n^{\circ}$ 5, November, 2010.

(2008). Global Player ou espectador nas margens? A "Responsabilidade de Proteger": Definição e Implicações para o Brasil. Revista da Escola de Guerra Naval, ${ }^{0} 12,2008$, pp.6-57.

KOSELLECK, Reinhart. (2006). Futuro Passado. Contribuição à semântica dos tempos históricos. Editora PUC-Rio, 2006.

. (1985). Begriffsgeschichte and social history. In: Futures past on the semantics of historical time. Cambridge (Mass.)/Londres: The MIT Press, 1985, pp. 73-91.

KRASNER, Stephen. (1999). Sovereignty: Organized Hypocrisy. Princeton: Princeton University Press, 1999.

LAMPREIA, Luiz Felipe. (2001). Discurso de despedida e passagem de cargo de ministro das Relações Exteriores a Celso Lafer. Brasília, 29 jan, $2001 . \quad$ Disponível em: <http://www.radiobras.gov.br/integras/01/integra_2901_6.htm> Acesso em: 10 out. 2011.

. (1999). Diplomacia brasileira: palavras, contextos e razões. Rio de Janeiro: Lacerda Editores, 1999. 
. (1996). O Brasil e o mundo no século XXI. Parcerias Estratégicas, vol.1, n.2, 1996.

LIMA, Maria Regina Soares de; HIRST, Monica. (2009). Brasil como país intermediário e poder regional. In: Os Brics e a ordem global. Rio de Janeiro: FGV, 2009.

LIMA, Maria Regina Soares de (2005). Autonomia, Não-Indiferença e Pragmatismo: Vetores Conceituais da Política Exterior. Revista Brasileira de Comércio Exterior, ㄲo 83. Edição Especial LATN Série Brief. A política comercial do governo Lula, maio-junho, 2005, pp. 16-20. Disponível em: <http://www.latn.org.ar/wpcontent/uploads/2012/03/Brief21.pdf> Acesso em: 5 fev. 2011.

LIMA, Maria Regina Soares de. (1994). Ejes analíticos y conflicto de paradigmas em La política exterior brasileña. America Latina Internacional. Argentina. FLACSO. v.1, no 2, 1994.

MACFARLANE, S.Neil; KHONG, Yuen Foon. (2006). Human Security and the UN: A Critical History. Bloomington: Indiana University Press, 2006.

MARQUES, Sylvia Ferreira. (2005). A imagem internacional do Brasil no governo Cardoso (1995-2002) - Uma leitura construtivista do conceito de potência média. Orientadora: Maria Regina Soares de Lima. Rio de Janeiro: PUC-Rio, Instituto de Relações Internacionais, 2005.

MAZZUOLI, Valerio de Oliveira. (2008). Curso de Direito Internacional Público. 3. ${ }^{a}$ ed. rev., atual e ampl. São Paulo: Editora Revista dos Tribunais, 2008.

MILNE, Selmas. (2011) If the Libyan war was about saving lives, it was a catastrophic failure: Nato claimed it would protect civilians in Libya, but delivered far more killing. The Guardian, 26 out. 2011. Disponível em:<http://www.guardian.co.uk/commentisfree/2011/oct/26/libya-warsaving-lives-catastrophic-failure>. Acesso em: 8 março 2012.

MOURA, Gerson. (1980) Autonomia na Dependência. Rio de Janeiro: Ed. Nova Fronteira, 1980. 
NETO, Danilo Marcondes de Souza. (2010). Operações de Paz e Cooperação Regional: O Brasil e o Envolvimento Sul-americano na MINUSTAH. Revista da Escola de Guerra Naval, Rio de Janeiro, no 15, p. 25-58, 2010.

NEVES, Gilda Motta Santos. (2009). Comissão das Nações Unidas para a Consolidação da Paz - Perspectiva brasileira. Brasília: FUNAG.

OEA (ORGANIZAÇÃO DOS ESTADOS AMERICANOS). (1991). Democracia Representativa. Resolução aprovada na quinta sessão plenária. Documento da OEA AG/RES. 1080 (XXI-0/91), 5 junho 1991. Disponível em:<http://www.oas.org/xxxiiga/portugues/documentos/democracia_repre s.pdf> Acesso em: 18 set. 2012.

ONU (ORGANIZAÇÃO DAS NAÇÕES UNIDAS). (2008). Secretário-Geral. Secretary-General defends, clarifies 'Responsibility to Protect' at Berlin Event on 'Responsibility Sovereignty: International Cooperation for a Changed World'. Documento das Nações Unidas SG/SM/11701, 15 julho 2008.2 Disponível em: <http://www.un.org/News/Press/docs/2008/sgsm11701.doc.htm> Acesso em: 20 fev. 2012.

. (2005). Assembleia Geral. World Summit Final Report. Documento das Nações Unidas A/RES/60/1, 24 out. 2005. Disponível em $<$ http://daccess-dds-

ny.un.org/doc/UNDOC/GEN/N05/487/60/PDF/N0548760.pdf?OpenEleme nt>. Último acesso em: 20 de fevereiro de 2012.

- (2005a). Assembleia Geral. In larger freedom: towards development, security and human rights for all. Report of the SecretaryGeneral. Documento das Nações Unidas A/59/2005, 21 março 2005a. Disponível em: <http://daccess-ddsny.un.org/doc/UNDOC/GEN/N05/270/78/PDF/N0527078.pdf?OpenEleme nt>. Acesso em: 5 set.2012.

. (2005b). Assembleia Geral. The Peacebuilding Commission. Documento das Nações Unidas A/RES/60/180, 30 dez. 2005b. Disponível em: $\quad<\quad$ http://daccess-ddsny.un.org/doc/UNDOC/GEN/N05/498/40/PDF/N0549840.pdf?OpenEleme nt> . Acesso em: 2 set. 2012. 
(2005c) Conselho de Segurança. Resolution 1646 (2005). Adopted by the Security Council at its 5335th meeting. Documento das Nações Unidas S/RES/1646 (2005), 20 dez. 2005c. Disponível em: $<$ http://www.mofa.go.jp/mofaj/gaiko/peace_b/pdfs/pbc_051220_scres164 6.pdf >. Acesso em: 5 jun. 2012.

. (2005d) Conselho de Segurança. Resolution 1645 (2005). Adopted by the Security Council at its 5335th meeting. Documento das Nações Unidas S/RES/1645 (2005), 20 dez. 2005d. Disponível em: $<$ http://www.undemocracy.com/S-RES-1645(2005).pdf>. Acesso em: 5 jun. 2012.

. (2004). Conselho de Segurança. Report of the Secretary-General on Haiti. Documento das Nações Unidas S/2004/300, 16 abril 2004. Disponível em: <http://www.un.org/ga/search/view_doc.asp?symbol=S/2004/300> Acesso em: 10 fev. 2012.

. (2004a). Conselho de Segurança. Resolution 1542 (2004). Adopted by the Security Council at its 4961st meeting. Documento das Nações Unidas S/RES/1542 (2004), 30 abril 2004a. Disponível em: <http://minustah.org/pdfs/res/1542_en.pdf>. Acesso em: 20 fev. 2012.

(2004b). Assembleia Geral. Painel de Alto Nível sobre Ameaças, Desafios e Mudanças. Documento das Nações Unidas A/59/565, 2 dez. 2004b. Disponível em: <http://daccess-ddsny.un.org/doc/UNDOC/GEN/N04/602/31/PDF/N0460231.pdf?OpenEleme nt>. Acesso em: 5 set. 2012.

. (2004c). Conselho de Segurança. Resolution 1529 (2004). Adopted by the Security Council at its 4919th meeting. Documento das Nações Unidas S/RES/1529 (2004), 29 fev. 2004c. Disponível em: <http://minustah.org/pdfs/res/1529_en.pdf>. Acesso em: 20 fev. 2012.

(2000). Assembleia Geral/Conselho de Segurança. Relatório Brahimi/ Report of the Panel on United Nations Peace Operations. Documento das Nações Unidas A/55/305-S/2000/809, 21 agos. 2000. Disponível em: <http://www.un.org/peace/reports/peace_operations/docs/a_55_305.pdf>. Acesso em: 6 set. 2012. 
. (1998). Conselho de Segurança. Resolution 1212 (1998). Adopted by the Security Council at its 3949th meeting. Documento das Nações Unidas S/RES/1212 (1998), 25 nov. 1998. Disponível em: <http://www.undemocracy.com/S-RES-1212(1998).pdf>. Acesso em: 20 fev. 2012.

. (1995). Assembleia Geral/Conselho de Segurança. Supplement to an Agenda for Peace: Position Paper of the Secretary-General on the Occasion of the Fiftieth Anniversary of the United Nations. Documento das Nações Unidas A/50/60-S/1995/1, 3 jan. 1995. Disponível em: <http://www.un.org/documents/ga/docs/50/plenary/a50-60.htm>. Acesso em: 20 agos. 2012.

(1994). Assembleia Geral. An Agenda for Development: Report of the Secretary-General. Documento das Nações Unidas A/48/935, 6 maio 1994. Disponível em: <http://www.un.org/Docs/SG/agdev.html>. Acesso em: 10 out. 2011.

. (1994a). Resolution 940 (1994). Adopted by the Security Council at its 3413th meeting. Conselho de Segurança. Documento das Nações Unidas S/RES/940, 31 julho 1994a. Disponível em:< http://www.worldlii.org/int/other/UNSCRsn/1994/48.pdf > Acesso em: 15 out. 2011.

. (1993). Resolution 875 (1993). Adopted by the Security Council at its 3293rd meeting. S/RES/ 875 (1993), 16 out. 1993a. Disponível em: <http://www.worldlii.org/int/other/UNSCRsn/1993/76.pdf >. Acesso em: 25 out. 2011.

. (1993a). Resolution 873 (1993). Adopted by the Security Council at its 3291st meeting. S/RES/873 (1993), 13 out. 1993b. Disponível em: <http://www.worldlii.org/int/other/UNSCRsn/1993/74.pdf>. Acesso em: 25 out. 2011.

. (1993b). Resolution 841 (1993). Adopted by the Security Council at its 3238th meeting. S/RES/841 (1993), 16 junho 1993c. Disponível em:<http://www.undemocracy.com/S-RES-841(1993).pdf>. Acesso em: 25 out. 2011. 
. (1992). Assembleia Geral/Conselho de Segurança. An Agenda for Peace: Preventive Diplomacy, Peacemaking and Peacekeeping. Report of the Secretary-General pursuant to the statement adopted by the Summit Meeting of the Security Council. Documento das Nações Unidas A/47/277-S/24111, 31 jan. 1992. Disponível em: $<$ http://www.unrol.org/doc.aspx?n=A_47_277.pdf>. Acesso em: 8 março 2012.

. (1992a). Conselho de Segurança. Resolution 794 (1992). Adopted by the Security Council at its 3145th meeting. Documento das Nações Unidas S/RES/794. 3 dez. 1992a. Disponível em: $<$ http://www.unrol.org/doc.aspx?n=A_47_277.pdf>. Acesso em: 8 março 2012.

. (1991). Assembleia Geral. Report of the Secretary-General on the Work of the Organization. Documento das Nações Unidas A/46/1, 13 set.1991.Disponível em: <http://www.undemocracy.com/A-46-1.pdf>. Acesso em: 14 set. 2012.

. (1971). Conselho de Segurança. Resolution 307 (1971). Documento das Nações Unidas S/RES/307 (1971), 21 dez. 1971. Disponível em:<http://www.unhcr.org/refworld/docid/3b00f21024.html> Acesso em: 10 fev. 2012.

. (1963). Conselho de Segurança. Resolution 181 (1963). Documento das Nações Unidas S/RES/181 (1963), 7 agos. 1963. Disponível em: <http://www.unhcr.org/refworld/type,RESOLUTION,,ZAF,3b00f20a30,0.ht ml>. Acesso em: 22 fev. 2012.

. (1962). Assembleia Geral. Resolution 1761(XVII). Documento das Nações Unidas A/RES/1761 (XVII), 6 nov. 1962. Disponível em:<http://daccess-dds-

ny.un.org/doc/RESOLUTION/GEN/NR0/192/69/IMG/NR019269.pdf?Open Element> Acesso em: 12 fev. 2012.

(1960). Assembleia Geral. Declaração de Garantia de Independência dos Países Coloniais. Documento das Nações Unidas A/RES/1514 (XV), 14 dez. 1960. Disponível em: <http://daccess-ddsny.un.org/doc/RESOLUTION/GEN/NR0/152/88/IMG/NR015288.pdf?Open Element>. Acesso em: 4 maio 2012. 
. (1950). Assembleia Geral. Uniting for Peace. Documento das

Nações Unidas A/RES/377 (V) A, 3 nov. 1950. Disponível em $<$ http://www.un.org/depts/dhl/landmark/pdf/ares377e.pdf>. Acesso em: 5 out. 2011.

. (1945). Carta das Nações Unidas, 1945. Disponível em:

<http://unicrio.org.br/img/CartadaONU_Versolnternet.pdf>. Acesso em: 6 de março de 2011.

PARIS, Roland. (1997). Peacebuilding and the limits of liberal internationalism. International Security, n. 22, 1997.

PATRICK, Stewart. (2011). Libya and the Future of Humanitarian Intervention: How Qaddafi's Fall Vindicated Obama and RtoP. Foreign Affairs, 26 agos. 2011. Disponível em: $<$ http://www.foreignaffairs.com/articles/68233/stewart-patrick/libya-andthe-future-of-humanitarian-intervention> Acesso em: 5 março 2012.

PATRIOTA, Antonio. (1998). O conselho de Segurança após a Guerra do Golfo: A articulação de um novo paradigma de segurança coletiva. Brasília: IRB/FUNAG, 1998.

PERICÁS, Bernardo. (1993). Intervenção do Representante Permanente do Brasil junto à OEA, Embaixador Bernardo Pericás, por ocasião da sessão extraordinária do Conselho Permanente, em 18 out. 1993. Arquivos da Missão do Brasil junto à OEA.

PICTET, Jean. (1979). The Fundamental Principles of the Red Cross. Geneva: Henry Dunant Institute, 1979.

PINHEIRO, Letícia. (2000). Traídos pelo Desejo: um ensaio sobre a teoria e a prática da política externa brasileira contemporânea. Contexto Internacional, vol. 22, n. 2, Rio de Janeiro, IRI-PUC/RJ, jul./dez 2000, p.305-334.

PINHEIRO, Letícia. (2004). Política Externa e Construção e Análise da Identidade Internacional do Brasil. IV Encontro da Associação Brasileira de Ciência Política. Campus da PUC-Rio. Rio de Janeiro, 2124 julho 2004. 
PINHEIRO, Leticia; VEDOVELI, Paula. (2010). Intelectuais, Burocracia e Democracia, 34 Encontro Anual da ANPOCS, Caxambu, out. 2010, ST 16: Intelectuais, cultura e democracia.

PNUD (PROGRAMA DAS NAÇÕES UNIDAS PARA O DESENVOLVIMENTO). (1990) Human Development Report 1990: Concept and Measurement of human development. Disponível em: <http://hdr.undp.org/en/media/hdr_1990_en_chap1.pdf>. Acesso em: 10 jan. 2012.

PNUD (PROGRAMA DAS NAÇÕES UNIDAS PARA O DESENVOLVIMENTO). (1994). Human Development Report 1994: New Dimensions of Human Security. Chap. 1 Towards sustainable human development.

Disponível em: <http://hdr.undp.org/en/media/hdr_1994_en_chap1.pdf> Acesso em: 10 jan. 2012.

PNUD (PROGRAMA DAS NAÇÕES UNIDAS PARA O DESENVOLVIMENTO). Relatório de Desenvolvimento Humano (RDH) de todos os anos. Disponível em:<http://hdr.undp.org/en/reports/> Acesso em: 15 jan. 2012.

ROSA, Renata de Melo. (2007). Relatório final de pesquisa de pósdoutorado. Diplomacia responsável: a intervenção do Brasil no Haiti. Univ. Rel. Int., Brasília, 2007.

RICHMOND, Oliver. (2010). Resistance and the Post-liberal Peace. Millennium, Vol. 38, No.3, 2010.

RUGGIE, John Gerard. (1996). The United Nations and the Collective Use of Force: whither - or whether? New York: UNA/USA, 1996.

SANTISO, Carlos. (2000). The Gordian Knot of Brazilian Foreign Policy: Promoting democracy while respecting sovereignty. Cambridge Review of International Affairs, vol.16, Number 2, July 2000.

SCHIRM, Stefan A. (2010). Leaders in Need of Followers: Emerging Powers in Global Governance. European Journal of International Relations, 16/2:197-221, 2010. 
SEITENFUS, Ricardo et al. (2007). O Direito Internacional repensado em tempos de ausência e emergências: a busca de uma tradução para o princípio da não-indiferença. Rev. Bras. de Política Internacional. 50 (2): 7-24. 2007.

SEN, Amartya. (2000). A Decade of Human Development. Journal of Human Development. Vol. 1, no. 1, 2000.

SHAPIRO, Michael J. (1982). Reading the Postmodern Polity: Political Theory as Textual Practice. Minneapolis: University of Minnesota Press, 1982.

SOUZA, Letícia Carvalho de. (2010). Dissertação de mestrado apresentada ao Programa de Pós-Graduação em Relações Internacionais da Pontifícia Universidade Católica de Minas Gerais, intitulada Segurança, Desenvolvimento e Reconstrução de Estados: $O$ caso da Libéria (2003-2008). Belo Horizonte. Orientador: Paulo ESTEVES.

STUENKEL, Oliver. (2011). Brazil and the responsibility while protecting. Post-Western World, 28 nov. 2011. Disponível em: <http://www.postwesternworld.com/2011/11/28/brazil-and-theresponsibility-when-protecting/> Acesso em: 18 de fevereiro de 2012.

THAKUR, Ramesh. (2011). The Responsibility to Protect: Norms, Laws and the Use of Force in International Politics. New York: Routledge, 2011.

TRATADO DO ATLÂNTICO NORTE (OTAN). (1949). Washington D.C, 4 abril $1949 . \quad$ Disponível em: $<$ http://www.nato.int/cps/en/natolive/official_texts_17120.htm>. Acesso em: 12 fev.2012.

VAZ, Alcides da Costa. (2006). O Brasil e o Sistema Interamericano: dos anos 1990 até o presente. In: OLIVEIRA, Henrique Altemani de; LESSA, Antônio Carlos. Relações Internacionais do Brasil: temas e agendas, v.2. São Paulo: Saraiva, 2006.

VIGEVANI, Tullo; CEPALUNI, Gabriel. (2007). A Política Externa de Lula da Silva: A Estratégia da Autonomia pela Diversificação. Contexto Internacional. Rio de Janeiro, vol. 29, $\mathrm{n}^{\circ}$ 2, julho/dezembro 2007, pp. 273-335. 
VIGEVANI, Tullo; OLIVEIRA, Marcelo F. de; CINTRA, Rodrigo. (2003). A política externa no governo FHC: a busca de autonomia pela integração. Revista Tempo Social, v.15, n.2, pp.31-61, 2003.

WEISS, Thomas; FORSYTHE, David; COATE, Roger. (2004). The United Nations and Changing World Politics. Oxford: Westview Press, 2004.

WEISS, Thomas G.; GORDENKER, L. (1993). Whither collective security? An unsettled idea in a changing world. In: WEISS, Thomas G. (Ed.). Collective Security in a changing world. Boulder, CO: Lynne Rienner Publishers, 1993.

WEISS, Thomas G. (1999). Military-Civilian Interactions: Intervening in Humanitarian Crisis. Lanham and New York: Rowman \& Littlefield Publishers, 1999.

WHEELER, Nicholas. (2000). Saving Strangers: humanitarian intervention in international society. Oxford: Oxford University Press, 2000.

WHEELER, Nicholas. (2004). The Humanitarian Responsibilities of Sovereignty: Explaining the Development of a New Norm of Military Intervention for Humanitarian Purposes in International Society. In: WELSH, Jennifer (Org.). Humanitarian Intervention in International Society. Oxford: Oxford University Press, 2004. pp. 29-51.

\section{Sites:}

BBC BRASIL. Reportagem sobre a desigualdade social no Brasil, segundo a ONU, em 2005: <http://www.bbc.co.uk/portuguese/reporterbbc/story/2005/09/050907_idhr w.shtml>. Acesso em: 20 fev. 2012.

COMITE INTERNACIONAL DA CRUZ VERMELHA: <http://www.icrc.org/por/war-and-law/treaties-customary-law/genevaconventions/index.jsp>. Acesso em: 2 março 2012.

FOLHA DE SÃO PAULO. Reportagem sobre o Coeficiente Gini e a colocação do Brasil na lista da ONU, em 2005: <http://www1.folha.uol.com.br/folha/cotidiano/ult95u112798.shtm>. Acesso em: 20 fev. 2012. 
JORNAL EXTRA. Reportagem sobre o jovem torturado na Vila Cruzeiro: $<$ http://extra.globo.com/casos-de-policia/jovem-torturado-na-vila-cruzeirodiz-ter-sido-intimidado-por-militares-da-forca-de-pacificacao4308527.html>. Acesso em: 15 março 2012.

NAÇÕES UNIDAS BRASIL. Reportagem sobre a ONU e os direitos humanos:<http://www.onu.org.br/a-onu-em-acao/a-onu-e-os-direitoshumanos/>. Acesso em: 2 de março de 2012; Reportagem sobre o IDH: <http://www.onu.org.br/rdh2011>. Acesso em: 14 fev. 2012.

NEW YORK TIMES. Reportagem sobre soldados brasileiros no Haiti: $<$ http://www.nytimes.com/2011/12/17/world/americas/haiti-un-investigatesmedia-reports-of-attacks-by-brazilianpeacekeepers.html?ref=departmentofpeacekeepingoperations>; <http:/topics.nytimes.com/topics/reference/timestopics/organizations/u/uni ted_nations/department_of_peacekeeping_operations/index.html>. Acesso em: 10 março 2012.

PNUD BRASIL: <http://www.pnud.org.br/home/>. Acesso em: 10 jan. 2012. 